AMARILIS INOCENTE BOCAFOLI

\title{
RESPONSABILIDADE ADMINISTRATIVA DOS FUNCIONÁRIOS PÚBLICOS POR INEFICIÊNCIA
}

\author{
DisSERTAÇão DE MESTRAdo \\ Orientador: Prof. Associado Dr. Edmir Netto de AraúJo
}

FACULDADE DE DIREITO DA USP

SÃO PAULO

2010 


\section{AMARILIS INOCENTE BOCAFOLI}

\section{RESPONSABILIDADE ADMINISTRATIVA DOS FUNCIONÁRIOS PÚBLICOS POR INEFICIÊNCIA}

Dissertação de Mestrado apresentada à Banca Examinadora da Faculdade de Direito da Universidade de São Paulo, como exigência parcial para a obtenção do título de Mestre em Direito, sob orientação do Prof. Associado Dr. Edmir Netto de Araújo

FACULDADE DE DIREITO DA USP SÃO PAULO 
Banca Examinadora 
Ao meu sobrinho, Eduardo, que perpetua a luz de sua mãe. 


\section{AGRADECIMENTOS}

Minha imensa gratidão ao Professor Edmir Netto de Araújo que, sempre atencioso e diligente, orientou-me na realização do presente trabalho, incentivando o desenvolvimento do estudo e mostrando-se sempre disponível para esclarecer minhas dúvidas e direcionar minhas ideias.

As críticas e sugestões dos Professores Fernando Dias Menezes de Almeida e Elival da Silva Ramos no exame de qualificação também foram imprescindíveis para a estruturação e conclusão definitiva do trabalho, de forma que rendo a eles minha grande gratidão.

Minha gratidão a Alexandre Cezar Freddo, Ariane Bocafoli Benez e Sérgio Eduardo Benez, que estiveram presentes durante toda a elaboração do trabalho, apoiando-me com compreensão e companhia reconfortante.

Agradeço aos meus companheiros da pós-graduação, que ajudaram a aprimorar o trabalho com sugestões e discussões acaloradas sobre os temas de Direito Administrativo nos intervalos das aulas.

Agradeço, ainda, aos funcionários da biblioteca da Faculdade de Direito da Universidade de São Paulo - USP, que, sempre muito diligentes e pacientes, atendem de forma simpática e prestativa às demandas dos usuários.

Aos meus colegas da Procuradoria Geral do Estado - Regional de Sorocaba, sobretudo meus chefes, Sandra e Maurício, agradeço a paciência e a ajuda sem as quais o trabalho jamais teria sido concluído. 
"A moral política não pode oferecer à sociedade qualquer vantagem perdurável, se não estiver baseada em sentimentos indeléveis do coração.

(...)

Façamos uma consulta, portanto, ao coração humano; encontraremos nele os preceitos essenciais do direito de punir."

Cesare Bonesana Beccaria. Dos delitos e das penas. 


\section{RESUMO}

A pesquisa tem por objeto o dever de eficiência cometido aos agentes públicos e a consequente penalização administrativa por inobservância desse dever, com foco nos servidores públicos estatutários. Não abordaremos a responsabilidade administrativa dos membros da magistratura e do Ministério Público, porque, além de haver divergência doutrinária sobre sua classificação dentro da categoria de agentes públicos ${ }^{1}$, são submetidos a um regime peculiar, pelo qual há liberdade de atuação e ausência de hierarquia administrativa, o que demandaria estudo aprimorado e específico sobre seu poder disciplinar, que não caberia neste trabalho por sua abrangência.

A fim de situar as expressões que constam do título do trabalho, será necessário um prévio estudo dos institutos relacionados com o tema central, tal como o conceito de funcionário público, o poder disciplinar do Estado, a responsabilidade administrativa, o princípio da eficiência e a eficiência como dever do funcionário público e como dever comutativo, quer dizer, que só pode ser cobrado do funcionário na exata medida em que o Estado lhe dá instrumentos que permitam uma atuação eficiente.

Abordaremos a responsabilidade dos funcionários públicos em seu sentido material e positivo, analisando-se, sobretudo, as consequências da ineficiência funcional previstas na Constituição Federal, nas legislações federal e paulista.

O trabalho terá por objeto, ainda, os limites e os parâmetros que devem conduzir a atividade discricionária do Poder Público na apuração da infração por ineficiência e na aplicação da respectiva penalidade para se extrair do poder disciplinar sua máxima efetividade no alcance da finalidade pública.

É dentro desse contexto, também, que se torna importante analisar a atuação do Poder Judiciário no controle dessa atividade, tanto para garantir que não haja arbitrariedade na atuação administrativa, como para evitar que retire do Poder Executivo sua autonomia na atividade punitiva disciplinar.

Por fim, o trabalho tem o fito de estabelecer uma relação entre a eficiência e o poder disciplinar, sendo, este último, forma garantidora do funcionamento normal, regular e ininterrupto, ou seja, eficiente, da máquina administrativa.

PALAVRAS-CHAVE: poder disciplinar, responsabilidade administrativa, funcionário público, eficiência, ineficiência.

\footnotetext{
${ }^{1}$ A divergência refere-se ao fato de serem eles agentes políticos ou funcionários públicos. Ver no sub-capítulo 2 da Introdução.
} 


\section{RIASSUNTO}

Questa ricerca ha come oggetto il dovere di efficienza spettante agli agenti pubblici e la conseguente penalizzazione amministrativa per la mancata osservanza di tale dovere, con foco nei funzionari pubblici statutari. Non esamineremo la responsabilità amministrativa dei membri della magistratura e del Ministero Pubblico, poiché, oltre ad esservi una divergenza dottrinaria per quanto riguarda la loro classificazione nella categoria di agenti pubblici ${ }^{2}$, essi sono sottoposti ad un regime peculiare, nel quale vi è libertà di operato ed assenza di una gerarchia amministrativa, il che richiederebbe uno studio approfondito e specifico circa il loro potere disciplinare che, vista la sua ampiezza, supererebbe i limiti del presente lavoro.

Sarà necessario uno studio preliminare degli istituti che sono in relazione con il tema centrale, come il concetto di funzionario pubblico, il potere disciplinare dello Stato, la responsabilità amministrativa, il principio di efficienza e l'efficienza come dovere del funzionario pubblico e come dovere commutativo, in altre parole, che può essere richiesto al funzionario soltanto nella misura esatta in cui lo Stato gli dà i mezzi che gli permettano un operato efficiente, al fine di situare le espressioni che constano nel titolo del lavoro.

Esamineremo la responsabilità dei funzionari pubblici in senso materiale e positivo, analizzando soprattutto le conseguenze dell'inefficienza funzionale previste nella Costituzione Federale, nella legislazione federale ed in quella dello Stato di São Paulo.

Questo lavoro, inoltre, avrà come oggetto i limiti ed i parametri che devono condurre l'attività discriminatrice del Potere Pubblico nella verifica dell'infrazione per inefficienza e nell'applicazione delle rispettive pene affinché il potere disciplinare sia il più effettivo possibile nel conseguire l'interesse pubblico.

In questo contesto, inoltre, è importante analizzare l'operato del Potere Giudiziario nel controllo di questa attività sia per garantire che non siano commesse arbitrarietà nell'operato amministrativo, che per evitare che questo impedisca l'autonomia del Potere Esecutivo nell' attività punitiva disciplinare.

Questo lavoro, infine, ha l'obiettivo di stabilire una relazione tra l'efficienza ed il potere disciplinare, essendo quest'ultimo, una forma di garantire il funzionamento normale, regolare ed ininterrotto, ossia, efficiente, della macchina amministrativa.

PAROLE CHIAVE: potere disciplinare, responsabilità amministrativa, funzionario pubblico, efficienza, inefficienza.

\footnotetext{
${ }^{2}$ La divergenza sarebbe relativa al fatto che essi sono agenti politici o funzionari pubblici. Vedere il paragrafo 2 dell'Introduzione.
} 


\section{SUMÁRIO}

INTRODUÇÃO

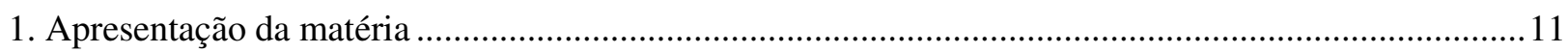

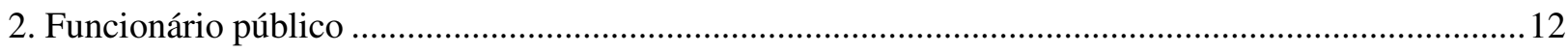

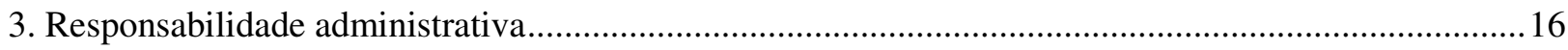

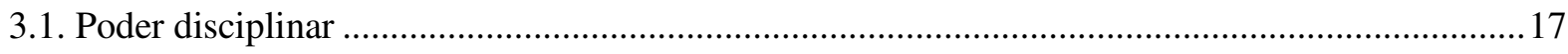

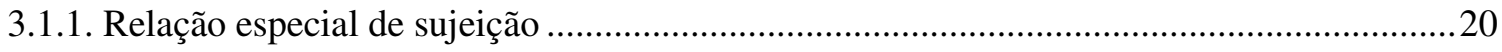

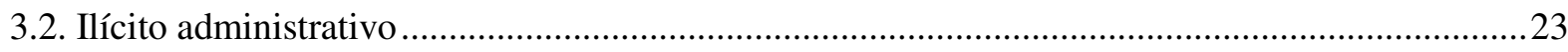

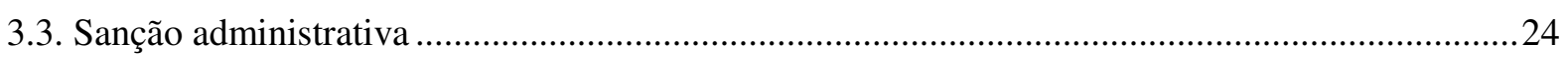

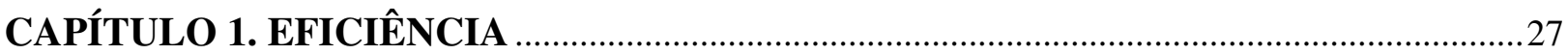

1.1. Introdução da eficiência no ordenamento jurídico pátrio .................................................................2

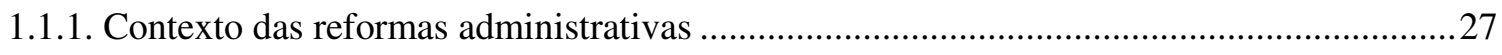

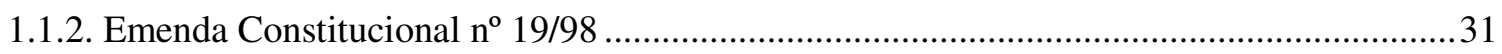

1.1.3. Eficiência na Ciência da Administração ............................................................................ 34

1.1.3.1. Direito Administrativo e Ciência da Administração..................................................34

1.1.3.2. Da importação, pelo Direito Administrativo, da eficiência da Ciência da

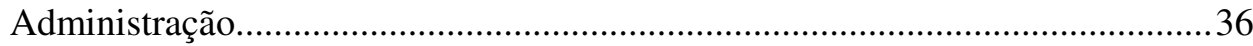

1.1.3.3. Conteúdo da eficiência na Ciência da Administração: eficiência, eficácia e

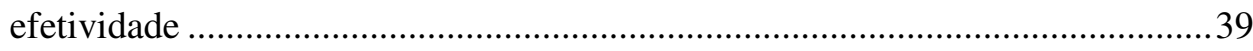

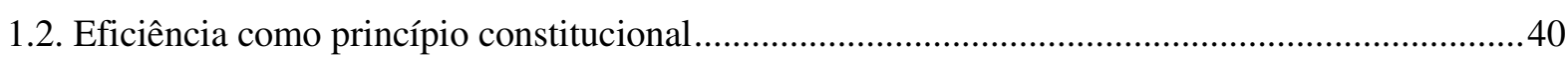

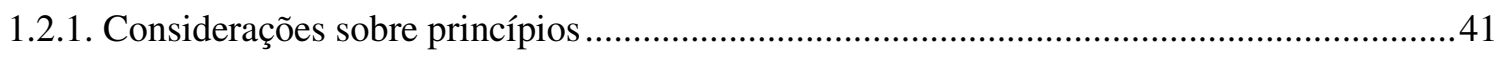

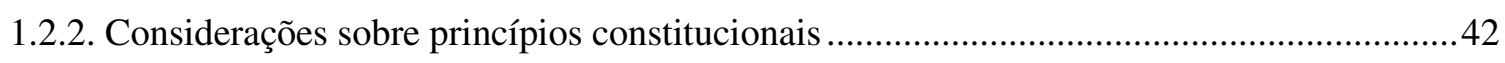

1.2.3. Eficiência como princípio constitucional-administrativo.................................................... 43

1.2.4. Fundamento do princípio da eficiência

1.2.5. Efeitos da introdução da eficiência como princípio na Constituição Federal .......................45

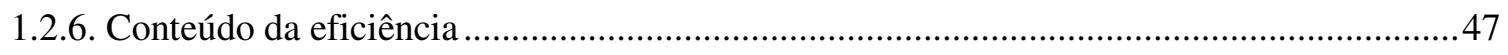

1.2.6.1. Eficiência como meio e como fim ......................................................................... 49

1.2.6.2. Parâmetros normativos do princípio da eficiência ....................................................51

CAPÍTULO 2. DEVER DE EFICIÊNCIA .............................................................................. 54

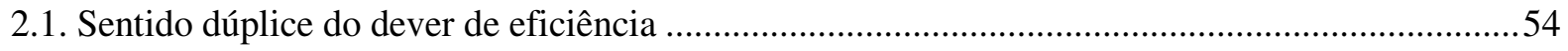

2.2. Instrumentos para o cumprimento do dever de eficiência .............................................................54 


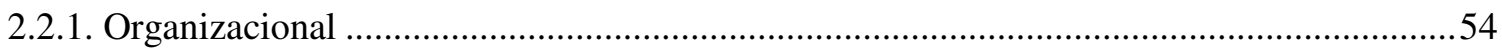

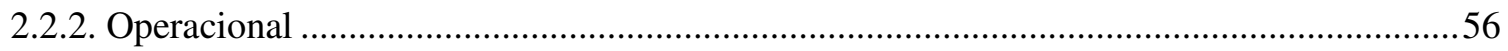

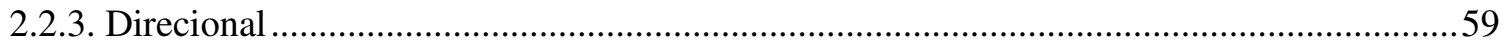

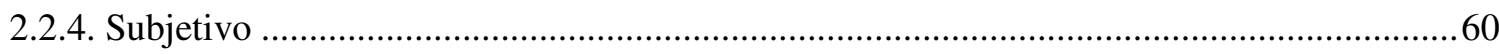

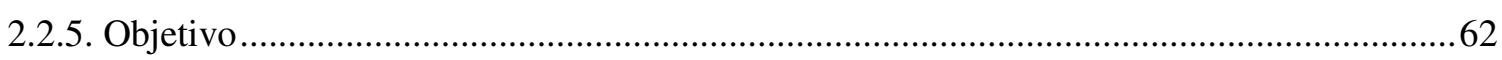

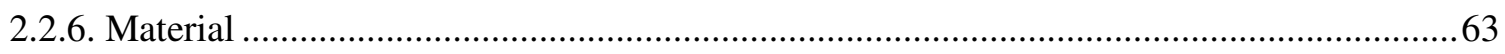

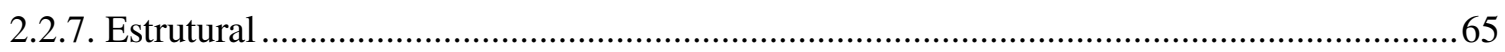

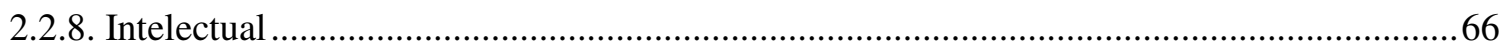

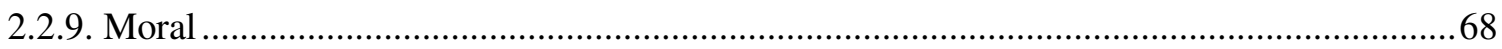

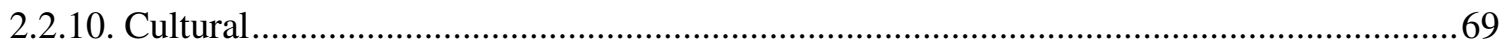

2.3. Dever de eficiência do funcionário público ………..................................................................... 70

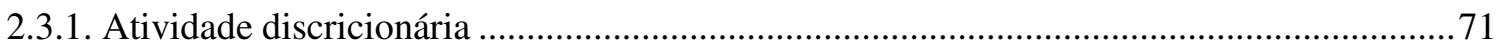

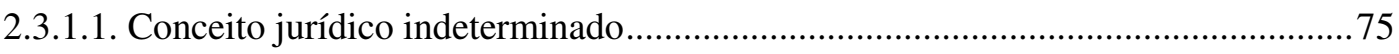

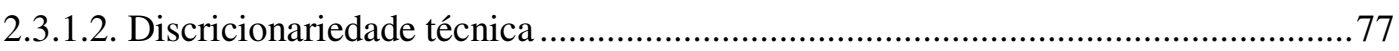

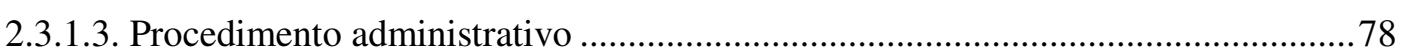

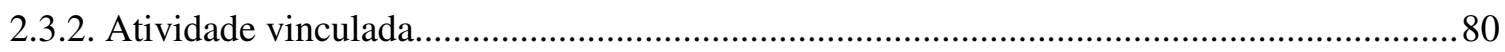

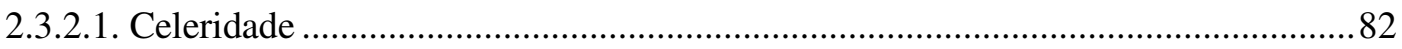

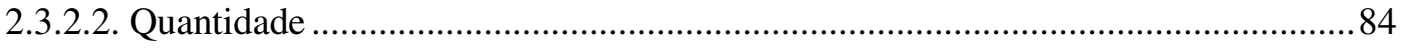

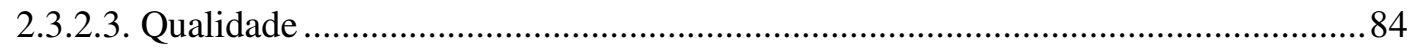

\section{CAPÍTULO 3. RESPONSABILIDADE ADMINISTRATIVA DO FUNCIONÁRIO PÚBLICO POR INEFICIÊNCIA ……………………………………….... 88}

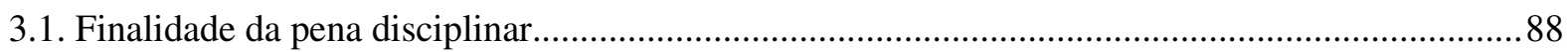

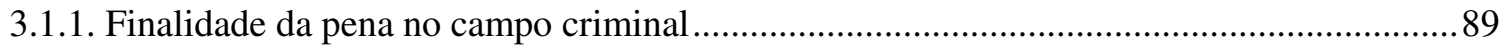

3.1.2. Finalidade da pena no campo administrativo ……........................................................... 90

3.1.3. Finalidade da pena no campo laboral .......................................................................... 90

3.1.4. Finalidade da pena no campo administrativo-disciplinar .................................................. 91

3.2. Poder disciplinar como instrumento para o cumprimento do dever de eficiência ..........................92

3.2.1. Poder disciplinar como fator de desestímulo dos funcionários públicos...............................94

3.2.2. Poder disciplinar como fator de estímulo dos funcionários públicos ..................................97

3.3. Responsabilidade administrativa por ineficiência no ordenamento jurídico pátrio ...................... 102

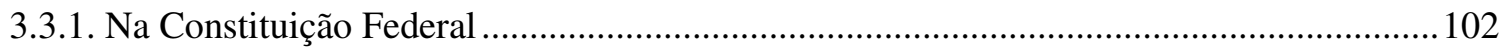

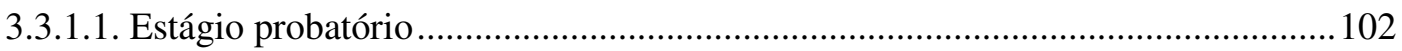

3.3.1.2. Avaliação periódica de desempenho....................................................................... 105

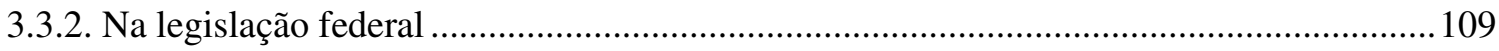

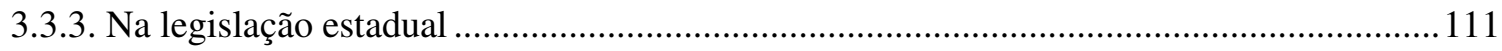


3.4. Controle judicial sobre a aplicação da pena por ineficiência .......................................................119

3.4.1. Controle judicial sobre a ineficiência administrativa

3.4.2. Controle judicial sobre a aplicação da pena administrativa

3.5. Parâmetros gerais para a tipificação e a punição da ineficiência do funcionário público 


\section{INTRODUÇÃO}

\section{Apresentação da matéria}

Nos últimos tempos, a Administração Pública assumiu proporções imensas, abrangendo atividades que garantem direitos sociais imprescindíveis para o desenvolvimento individual dos administrados e da sociedade como um todo. A atual Constituição Federal é extensa ao definir obrigações do Estado e garantias dos administrados, e, para o efetivo cumprimento dessas atividades complexas e importantes, é necessário que sua atuação seja realizada da forma mais eficiente possível.

A existência da eficiência se revela na prestação da atividade estatal para a população, que analisa, de plano, o sucesso ou fracasso da administração pública. Assim, a atuação ineficiente do Estado apresenta-se ao administrado de forma imediata e perceptível.

Os agentes públicos são parte importante nesse processo, já que é por meio deles que o Estado se relaciona com os administrados, constituindo sua "face visível" ". É esse elemento humano que concretiza a atuação do Estado abstrato, que fornece a "referência primeira e imediata que o cidadão usuário tem das atuações administrativas."2 "Por essa razão é que a qualidade e a eficiência do Serviço Público dependem, em grande escala, desses servidores." 3

É necessário reconhecer que existem funções públicas que constituem um núcleo básico de atividades de competência exclusiva do Estado. Por isso, é improtelável que a atenção do presente trabalho esteja destinada ao conjunto de agentes que exercem tais funções que, por sua vez, possuem regime institucional estatutário que prescreve garantias compatíveis com a importância de suas atividades, protegendo-os contra atos arbitrários de governantes ou outros agentes públicos transitórios ou mal intencionados.

\footnotetext{
${ }^{1}$ MOURA, Paulo Veiga e. Função pública: regime jurídico, direitos e deveres dos funcionários e agentes. 2. ed. Coimbra: Coimbra Ed., 2001. v. 1, p. 19.

${ }^{2}$ SOARES, Fabiana de Menezes. Função administrativa, estabilidade e princípio da neutralidade: alguns apontamentos sobre a reforma administrativa. Revista de Direito Administrativo, Rio de Janeiro, n. 211, p. 301-318, jan./mar. 1998.

${ }^{3}$ COSTA, José Armando da. Teoria e prática do direito disciplinar. Rio de Janeiro: Forense, 1981. p. 2.
} 
Para garantir a atuação escorreita desses agentes, eles se submetem ao denominado poder disciplinar, que tem por finalidade assegurar a ordem interna dos serviços, mantendo a fidelidade dos agentes aos fins perseguidos pela pessoa coletiva de direito público mediante a observância dos deveres prescritos em lei. Por meio do poder disciplinar, aplicam-se sanções consubstanciadas na supressão ou restrição dos direitos de funcionário, visando a manutenção, a correção ou o restabelecimento da disciplina do serviço público, propiciando, assim, o cumprimento da lei e dos princípios jurídicos e, por consequência, a manutenção da boa ordem da Administração.

Deve-se ter em mente, entretanto, que a relação existente entre o agente e o Estado é de natureza profissional e que a profissão integra a personalidade do indivíduo, pois, em geral, é fruto de conquista e esforço pessoal; manifesta-se diariamente e impõe ao indivíduo a forma como é visto perante a sociedade. Portanto, o poder disciplinar, na mesma atuação garantidora da ordem interna e da eficiência da Administração Pública, deve ser utilizado de forma a não causar ofensa ou desestímulo profissional. O poder disciplinar deve ser utilizado de forma adequada, sob pena de subversão da sua finalidade e comprometimento da atuação eficiente do funcionário público.

O presente trabalho estará focado na análise da eficiência no ordenamento jurídico, na sua repercussão na atividade dos agentes públicos e, sobretudo, no exercício do poder disciplinar, isto é, será analisada a eficiência como dever do funcionário público, como objeto de infração e como fundamento e finalidade do próprio sistema disciplinar, com o fito de orientar os julgadores e contribuir para uma efetiva consecução de sua finalidade: o bom andamento do serviço público, interesse de toda a sociedade.

Para tanto, a presente introdução tratará dos institutos relacionados ao título do trabalho, trazendo a delimitação do presente estudo para, a seguir, tratarmos do tema propriamente dito.

\section{Funcionário público}

O Estado desenvolve diversas funções e atividades, todas destinadas à manutenção de sua organização e ao atendimento das necessidades da coletividade.

O Estado, como já dito, é ente abstrato. Sua vontade é manifestada por meio de 
pessoas que agem e se manifestam em seu nome: os agentes públicos.

Todas as pessoas que vivem em sociedade possuem vínculos de diversas naturezas com o Estado. Os agentes públicos, entretanto, possuem uma relação mais estreita, porque desempenham a atividade concreta do Estado, isto é, representam o próprio Estado, exprimem sua vontade.

Assim, de acordo com o mais clássico e abrangente conceito: "Todos aqueles que prestam serviços ao Poder Público (União, Estados, Municípios e respectivas autarquias) ou realizam atividades da alçada deste podem ser designados agentes públicos”, desde que exprimam "um poder estatal, munidos de uma autoridade que só podem exercer por lhes haver o Estado emprestado sua força jurídica, exigindo ou consentindo-lhes o uso, para satisfação de fins públicos"4.

A Constituição Federal de 1988 não fornece uma uniformidade ao tratar da classificação, dos conceitos e da nomenclatura dos agentes públicos.

Para a maior parte da doutrina, seriam servidores públicos aqueles que prestam serviços ao Estado mediante relação de trabalho, não eventual, sob vínculo de dependência econômica, e se submetem à hierarquia e à subordinação.

Os servidores públicos, em sua maioria, estão sujeitos a dois regimes jurídicos: o estatutário e o trabalhista. Os primeiros são titulares de cargos e os segundos, de emprego.

A adoção de um regime ou de outro, quer dizer, o estatutário ou o celetista, deve levar em conta a natureza da atividade a ser desenvolvida pelo servidor público, de forma que as atividades típicas do Estado deveriam ser necessariamente prestadas por titulares de cargos e as atividades atípicas e/ou funções materiais subalternas deveriam ser prestadas mediante o regime celetista ${ }^{5}$. Nesse sentido, afigurou-se importante a mudança implementada pela Emenda Constitucional $\mathrm{n}^{\circ} 19$, de 4 de junho de 1998, no sentido de afastar a obrigatoriedade do regime único de pessoal para as respectivas Administrações direta, autárquicas e fundacionais, prevista, inicialmente, nos artigos 39 da Constituição Federal e 24 do Ato das Disposições Constitucionais Transitórias, permitindo o devido enquadramento de cada função ao tipo de regime adequado.

\footnotetext{
${ }^{4}$ MELLO, Celso Antônio Bandeira de. Apontamentos sobre os agentes e órgãos públicos. São Paulo: Ed. Revista dos Tribunais, 1972. p. 3-4.

${ }^{5}$ Nesse mesmo sentido: COELHO, Paulo Magalhães da Costa. Manual de direito administrativo. São Paulo: Saraiva, 2004. p. 109. MELLO, Celso Antônio Bandeira de. Curso de direito administrativo. 26 ed. rev. e atual. até a Emenda Constitucional 57, de 18.12.2008. São Paulo: Malheiros Ed., 2009. p. 261.
} 
Concordamos com Celso Antônio Bandeira de Mello, para quem, nas pessoas jurídicas de direito público (administração direta, autarquias e fundações), deve prevalecer o regime estatutário, entre outras razões, porque somente ele é concebido para atender a peculiaridades de um vínculo no qual não está em questão somente a relação de emprego, mas avultam interesses públicos básicos, atribuindo proteções peculiares para o manejo do cargo de uma maneira isenta, imparcial e obediente exclusivamente ao interesse público, e não a governantes do momento. Para ele, entretanto, mesmo no âmbito destas pessoas jurídicas, é possível haver sujeitos que se relacionam com a Administração Pública sob o regime contratual trabalhista, exercendo atividades que se referem a serviços materiais subalternos, cuja atuação não compromete uma ação impessoal do Estado ${ }^{6}$.

O emprego público representaria exceção ao regime estatutário, sendo reservado a atividades destituídas de relevância política, atividades não essenciais à satisfação dos direitos fundamentais e que não necessitam de poderes de maior consistência jurídica.

A questão foi tratada no julgamento da liminar da Ação Direta de Inconstitucionalidade $\mathrm{n}^{\circ}$ 2.310-1-DF, a qual foi concedida para se suspender a eficácia de determinados artigos da Lei ${ }^{\circ}$ 9.986, de 18 de julho de 2000, que "dispõe sobre a gestão de recursos humanos das Agências Reguladoras e dá outras providências", sobretudo porque estabeleciam que as relações de trabalho das agências reguladoras seriam regidas pela Consolidação das Leis do Trabalho, em regime de emprego público.

O Ministro Marco Aurélio fundamentou a concessão da liminar no fato de que os servidores das agências reguladoras não poderiam ser titulares de emprego público, na medida em que as atividades por eles exercidas, inerentes à atividade precípua do Estado (poder de polícia, poder normativo e de regulação da atividade econômica), serviço público típico, obrigariam que eles gozassem das garantias próprias do regime estatutário, que garante uma atuação equidistante, imune aos aspectos políticos ${ }^{7}$.

Nessa linha, em que pese isso não se aplicar na prática, determinadas atividades devem ser realizadas por pessoas titulares de cargos e outras devem ser realizadas por pessoas que exercem emprego público, até mesmo por força da atual tendência de se deixar para o Estado somente as atividades indelegáveis e as que o particular não tenha condições

\footnotetext{
${ }^{6}$ MELLO, Celso Antônio Bandeira de. Curso de direito administrativo, cit., p. 258-261.

${ }^{7}$ A ação não teve julgamento definitivo de mérito por perda de objeto. É que a matéria nela tratada foi revogada pela Lei $n^{\circ} 10.871$, de 20 de maio de 2004, que, em seu artigo $6^{\circ}$ dispôs que "o regime jurídico dos cargos e carreiras referidas no art. $1^{\circ}$ desta Lei é o instituído na Lei $n^{\circ} 8.112$, de 11 de dezembro de 1990, observadas as disposições desta Lei” e, por meio de seu art. $1^{\circ}$, criou carreiras e cargos efetivos para as Agências Reguladoras.
} 
de desempenhar sozinho ${ }^{8}$. É imprescindível que as competências estatais, fundamentais e essenciais, sejam exercidas por indivíduos submetidos a vínculo jurídico apropriado, com estabilidade e outras características do regime estatutário ${ }^{9}$, sendo o mesmo dispensado quando se trata de atividades que deveriam ser exercidas apenas por empregados públicos.

A Constituição Federal contempla os servidores estatutários com garantias específicas em prol de uma atuação imparcial e, consequentemente, eficiente, fazendo-se concluir que se enquadram neste regime somente aqueles que precisam de tais garantias no exercício de suas funções

Nesse sentido, Juarez Freitas escreveu:

Por mais que se entenda a proposta de flexibilização, o regime estatutário ou institucional é vital para que se alcancem os desideratos constitucionais. O constituinte derivado, apesar das vastas reformas que vem promovendo na esfera dos direitos dos servidores públicos - não raro, desafiadoras, para dizer o mínimo, da resiliência constitucional -, felizmente não abandonou, de um modo, a linha de que, para a segurança da sociedade, convém reservar aos ocupantes de certos cargos efetivos um tratamento especial, apto a propiciar a formação de Carreiras a salvo de cooptações partidárias e da previsível descontinuidade governativa. ${ }^{10}$

Portanto, são estatutários aqueles que se submetem ao conjunto de normas jurídicas que dispõem sobre o regime jurídico de direito público, denominado estatuto, previamente definido, estabelecido por lei por cada uma das unidades da federação, derrogatório e exorbitante do direito comum, pelo qual a Administração Pública possui posição de supremacia, podendo, inclusive, alterar unilateralmente as regras, de acordo com o interesse público, respeitados o direito adquirido, a coisa julgada e o ato jurídico perfeito.

Os servidores estatutários são sempre ocupantes de cargos de natureza permanente e podem ser conhecidos como servidores públicos em sentido estrito ou funcionários públicos.

\footnotetext{
${ }^{8}$ Conforme DI PIETRO, Maria Sylvia Zanella. 500 anos de direito administrativo brasileiro. In: AMARAL, Ana Lucia; FRISCHEISSEN, Luiza Cristina Fonseca; COSTA, Paula Bajer Fernandes Martins da. (Coords.). 500 anos e o direito no Brasil. São Paulo: Artchip Ed., 2000. p. 37-69.

${ }^{9}$ Nesse sentido: JUSTEN FILHO, Marçal. Curso de direito administrativo. 4. ed. rev. e atual. São Paulo: Saraiva, 2009. p. 834.

${ }^{10}$ FREITAS, Juarez. Discricionariedade administrativa e o direito fundamental à boa administração pública. A sindicabilidade aprofundada dos atos administrativos. Os vícios de arbitrariedade por excesso ou omissão. A era da motivação administrativa. A responsabilidade do Estado por ações e omissões. A releitura de institutos à luz do direito à boa administração. Os princípios da prevenção e da precaução. $O$ Estado-Administração, os objetivos fundamentais e o desenvolvimento humano. A valorização das Carreiras do Estado. 2. ed. São Paulo: Malheiros Ed., 2009. p. 121.
} 
Como já foi dito, os servidores que exercerem atribuições exclusivas de Estado devem se submeter, obrigatoriamente, ao regime jurídico estatutário, incluindo-se neles, além da Magistratura, Ministério Público, Tribunal de Contas, Advocacia Pública e Defensoria Pública, que exercem atribuições constitucionais, as áreas de polícia civil, de polícia militar, de controle, de fiscalização, de diplomacia e de regulação. Há, ainda, os servidores que trabalham em serviços auxiliares da justiça, nos termos do artigo 96, I, $e$, da Constituição Federal ${ }^{11}$.

Hely Lopes Meirelles entende que os membros da magistratura, do Ministério Público e dos Tribunais de Contas, por exercerem atribuições constitucionais e possuírem liberdade de atuação seriam, na verdade, agentes políticos. Isso porque, ao conceito de agente político, aquele que exerce atribuições constitucionais, o autor acrescenta as "autoridades que atuem com independência funcional no desempenho das atribuições governamentais, judiciais ou quase-judiciais, estranhas ao quadro do serviço público" ${ }^{\prime 2}$. Para ele, ainda, "todos os cargos vitalícios são ocupados por agentes políticos"13.

Todos os agentes públicos são vinculados ao dever de eficiência. No entanto, tendo em vista que o estudo se foca nas normas constitucionais e legais destinadas aos funcionários públicos, somente estes serão objeto do presente trabalho.

\section{Responsabilidade administrativa}

Previstas desde a Constituição de 1937, no Decreto-Lei n ${ }^{\circ} 1.713$, de 28 de outubro de 1939 (artigo 230), o primeiro Estatuto dos Funcionários Públicos Civis da União, há três esferas tradicionais de responsabilização do funcionário público: civil, criminal e administrativa, havendo plena independência entre elas.

A responsabilidade administrativa é a "obrigação de responder perante a Administração pela prática de ilícito administrativo na infração de regras de conduta relacionadas à função pública, desdobrando-se em ilícito disciplinar e funcional”14.

O funcionário público ou o servidor público em sentido estrito, como já

\footnotetext{
${ }^{11}$ Conforme DI PIETRO, Maria Sylvia Zanella. Direito administrativo. 22. ed. São Paulo: Atlas, 2009. p. 515.

${ }^{12}$ MEIRELLES, Hely Lopes. Direito administrativo brasileiro. 33. ed. São Paulo: Malheiros Ed., 2007. p. 79.

${ }^{13}$ Id. Ibid., p. 418.

${ }^{14}$ ARAÚJO, Edmir Netto. Curso de direito administrativo. 4. ed. São Paulo: Saraiva, 2009. p. 878.
} 
mencionado, ao estabelecer seu vínculo com a Administração Pública, passa a se sujeitar a um regime jurídico previamente definido, que trata de seus direitos, deveres, condições de trabalho, normas disciplinares, vencimentos, vantagens. Trata-se de normas de ordem pública, que não são passíveis de alteração nem mesmo com a concordância da Administração Pública e do funcionário, nas quais estão contidas todas as especificações da responsabilidade administrativa.

\subsection{Poder disciplinar}

A responsabilidade administrativa no âmbito profissional decorre do exercício do poder disciplinar. Este poder punitivo se diferencia daquele aplicado ao âmbito geral de atuação do Estado, no qual ele possui uma relação de supremacia geral em relação aos administrados.

A relação de supremacia geral consiste naquela "originada e regulada fundamentalmente por atos normativos e que liga uma entidade administrativa, de natureza pública e detentora de prerrogativas de autoridade, a um particular qualquer" ${ }^{\prime 15}$. Por meio dela, o Estado exerce atividade punitiva em duas frentes: a que se baseia no direito penal e a que se baseia no poder de polícia; a primeira é judicial e a segunda, administrativa.

O poder de polícia decorre da posição de supremacia geral da Administração Pública em relação a todos os cidadãos; seu desenvolvimento está intimamente ligado com o desenvolvimento dos ilícitos penais. É que, mesmo com a adoção do direito penal legalizado e judicializado a partir da Revolução Francesa, não foi abandonado o sistema sancionatório administrativo ${ }^{16}$, que manteve a atividade preventiva do Estado, visando a manutenção da ordem jurídica. A atividade sancionatória administrativa, entretanto, limitava-se à função de defender e conservar a ordem e a paz social, tendo em vista que o modelo liberal de Estado e a Separação de Poderes implantados limitaram o uso do poder sancionador pela Administração Pública ${ }^{17}$. Antes disso, durante o absolutismo, porém, não

\footnotetext{
${ }^{15}$ PRATES, Marcelo Madureira. Sanção administrativa geral: anatomia e autonomia. Coimbra: Livr. Almedina, 2005. p. 212-213.

${ }^{16}$ GARCÍA DE ENTERRÍA, Eduardo; FERNÁNDEZ, Tomáz-Ramón. Curso de direito administrativo II. 9. ed. Madrid: Thomson Civitas, 2004. p. 164.

${ }^{17}$ PRATES, Marcelo Madureira. op. cit., p. 30-31.
} 
era possível distinguir o direito penal do direito administrativo ${ }^{18}$.

O poder punitivo denominado disciplinar, por sua vez, se desenvolveu de forma autônoma ${ }^{19}$ e partiu da origem da própria estrutura administrativa.

Em síntese, o reconhecimento da existência do Direito Administrativo Disciplinar não decorre da evolução natural do Direito Administrativo do qual se teria desprendido, mas de sua própria essência, que não pode mais deixar de estabelecer a função normativa disciplinar que lhe é própria, destacando-a dos dispositivos legais, genéricos, relativos à participação do homem nas atividades administrativas oficiais. ${ }^{20}$

É antiga a origem da estrutura administrativa. Apesar de escapar ao nosso conhecimento os institutos existentes antes da introdução da escrita nos diversos povos, o que se sabe é que nesse período já existia uma organização relativamente desenvolvida dos grupos sociopolíticos, no domínio daquilo a que hoje chamamos direito público ${ }^{21}$.

O fato é que, desde os primórdios das relações humanas, existem tarefas desempenhadas por agentes do Estado que objetivavam o atendimento de interesses da coletividade (tais como defesa das povoações, ordem interna, limpeza, provisões, etc.), bem como respectivas regras disciplinadoras dessa relação entre coletividade e indivíduos, revestidas de poder coercitivo, que garantiam a pacífica subsistência do grupo ${ }^{22}$. Desde aquela época, "o ser humano abdicou de parte de sua liberdade natural de ação em favor de um comando e de uma disciplina que assegurasse a referida coexistência, sua própria segurança, e a prosperidade possível nas suas condições", buscando-se, assim, o “equilíbrio da vida em comum",23.

Segundo Paulo Francisco Bastos Von Bruck Lacerda, desde o Egito antigo, ao longo dos séculos XXVIII a XXIII antes de Cristo, já era possível se identificar um sistema jurídico desenvolvido, com estruturas administrativas e judiciárias elaboradas. Dessa estrutura organizada e complexa decorreria a conclusão sobre a existência de um mínimo de normas de conduta a serem observadas pelos súditos e servidores do reino, com regras

\footnotetext{
${ }^{18}$ MIR, José Cerezo. Sanções penais e administrativas do direito espanhol. Revista Brasileira de Ciências Criminais. São Paulo, v. 1, n. 2, p. 27-40, abr./jun. 1993.

${ }^{19}$ Nesse sentido: ZANOBINI, Guido. Rapporti fra il diritto amministrativo e il diritto penale. In: SCRITTI vari di diritto pubblico. Milano: Giuffrè, 1955. p. 136-137.

${ }^{20}$ LUZ, Egberto Maia. Direito administrativo disciplinar: teoria e prática. 3. ed. rev., ampl. e atual. São Paulo: Ed. Revista dos Tribunais, 1994. p. 64.

${ }^{21}$ Conforme GILISEN, John. Introdução histórica ao direito. 3. ed. Lisboa: Fundação Calouste Gunbenkian, 2001. p. 31.

${ }^{22}$ RAMOS, Dora Maria de Oliveira. Terceirização na administração pública. São Paulo: LTr, 2001. p. 89.

${ }^{23}$ ARAÚJO, Edmir Netto. op. cit., p. 1-2.
} 
disciplinadoras da conduta dos funcionários e procedimentos sancionatórios para coibir eventuais infrações a tais normas ${ }^{24}$.

A disciplina é, em todo ordenamento social, a base de uma estrutura social que garante a paz e o progresso. Por isso o poder disciplinar e a consequente responsabilidade do funcionário público possuem relação direta com a estrutura administrativa, sendo inerente ao bom funcionamento da mesma e para a realização de seus fins. Nesse sentido é que, desde que constatada a existência de organização administrativa, encontram-se traços da existência de um respectivo poder disciplinar correspondente e embasador do mesmo ${ }^{25}$.

Grandes transformações ocorreram a partir do final do século XVIII com o desenvolvimento de novas ideias políticas e jurídicas, dando origem às revoluções liberais na Europa, que animaram o surgimento do Estado de Direito. A Revolução Americana de 1776 e a Revolução Francesa de 1789 concretizaram as ideias de legalidade e a separação de poderes que regeriam o novo modelo, visando à limitação do poder do Estado e a preservação dos direitos individuais.

A submissão do Estado ao império das leis, obrigando sua obediência a um ordenamento jurídico pré-estabelecido, e o reconhecimento dos direitos individuais, garantias contra os desmandos do Estado anteriormente absolutista, acarretaram o surgimento do direito administrativo como ciência e disciplina autônomas. Foi a partir desse momento que as relações entre os particulares e o Estado e deste com seus agentes passaram a se estruturar juridicamente mediante um conjunto de normas estáveis.

Desenvolve-se, então, a visão acerca do agente público que passa a atuar conforme a finalidade do Estado, o interesse público, e passa a responder por suas ações. Tais agentes possuem vínculo profissional mediante uma relação denominada "relação de sujeição especial", sendo ela o fundamento do poder disciplinar, que, por sua vez, é um dos meios de se assegurar o alcance da finalidade de disciplina do comportamento pessoal dos indivíduos em contato com essa esfera administrativa especial, condenando o comportamento que prejudique a boa atuação da administração pública, mediante a aplicação de punições.

\footnotetext{
${ }^{24}$ LACERDA, Paulo Francisco Bastos von Bruck. Fundamentos do processo administrativo disciplinar: justiça administrativa. 2004. Dissertação (Mestrado) - Faculdade de Direito, Universidade de São Paulo, São Paulo, 2004. p. 18-19.

${ }^{25}$ Conforme Id. Ibid., p. 20-24.
} 


\subsubsection{Relação especial de sujeição}

$\mathrm{Na}$ relação de "supremacia geral", o Estado exerce seus poderes "indistintamente sobre todos os cidadãos que se sujeitam ao império das leis", ou seja, é a Administração Pública enquanto expressão do Estado ${ }^{26}$. Na relação de "sujeição especial”, o indivíduo entra na esfera jurídica e material ${ }^{27}$, da Administração Pública, que, por sua vez, desenvolve uma especial e mais acentuada disciplina do comportamento pessoal com o fim de obter uma melhor atuação administrativa. Nesse sentido, há "manifestações impositivas da Administração que, embora limitadoras da liberdade, promanam de vínculos ou relações específicas firmadas entre o Poder Público e o destinatário de sua ação", originam-se de um título jurídico especial ${ }^{28}$.

Trata-se de uma relação diferente, portanto, daquela que os cidadãos em geral possuem com o Estado. É uma relação especial, um vínculo mais estreito, pela qual o administrado entra em contato de uma forma mais direta e imediata com a instituição administrativa $^{29}$; é uma relação qualificada, que, geralmente, se estabelece por vontade do próprio particular.

O poder disciplinar é o regime sancionatório aplicado a essa relação especial, no qual o Estado atua, protegendo seus interesses específicos e internos, enquanto, nos demais casos, o Estado representa a própria coletividade.

Pois bem, por causa do vínculo peculiar que caracteriza a denominada "relação especial de sujeição", entende-se que o poder disciplinar que dela decorre possuiria algumas particularidades que autorizariam a preterição do princípio da legalidade, dos direitos fundamentais e da proteção judicial.

Diz-se que, quando a Administração Pública age com base na relação específica, alguns princípios constitucionais punitivos poderiam ser mitigados, pois o complexo de relações existente entre subordinados e o Estado se limitaria ao âmbito interno de sua atuação, diria respeito somente ao Estado, ao Estado como empregador, e não como

\footnotetext{
${ }^{26}$ ALESSI, Renato. Sistema istituzionale del diritto amministrativo italiano. Milano: Giuffrè, 1953. p. 201.

${ }^{27}$ Nesse sentido: ZANOBINI, Guido. Le sanzioni amministrative. Torino: Fratelli Bocca Editori, 1924. p. 133-134.

${ }^{28}$ MELLO, Celso Antônio Bandeira de. Curso de direito administrativo, cit., p. 816.

${ }^{29}$ GARRIDO FALLA, Fernando. Tratado de derecho administrativo: parte general: conclusion. 11. ed. Madrid: Tecnos, 1989. v. 2.
} 
organizador da sociedade e garantidor dos direitos dos cidadãos ${ }^{30}$.

De fato, a disciplina interna rege a relação existente entre a Administração Pública e aqueles que a ela se sujeitam por força de um vínculo especial, que não aquele advindo do simples fato de se pertencer à sociedade. No caso dos agentes públicos, esta relação se estabelece por meio de vínculo de natureza profissional.

Ocorre que há, na relação entre funcionário-Estado, muito mais do que uma relação interna, "doméstica" 31 , de interesse exclusivo das partes que integram a relação. O funcionário público exprime e expressa a vontade e os atos do Estado, sendo, na verdade, mais que um mero instrumento, mas parte integrante de sua estrutura.

Sendo assim, as regras que se referem a tal relação jurídica vão além da ordem interna, porque, ao lado de regularem a organização e disciplina internas, objetivam, acima de tudo, assegurar o pleno e regular funcionamento da atividade pública, interesse de toda coletividade. Visam, assim, uma atuação eficiente, que atenda às necessidades da sociedade.

Portanto, a relação que se estabelece entre o Estado e seus funcionários, principalmente no que se refere ao campo disciplinar, que é o instrumento normativo eficaz de se conduzir comportamentos, transborda o âmbito interno, na medida em que se subordina, também, ao interesse público.

Isso se comprova ao constatarmos que os valores jurídicos atingidos pelas infrações administrativas gerais e pelas disciplinares, apesar de serem diferentes (na primeira se protege a ordem pública e na segunda a ordem interna), ampliam-se de forma tal que atingem o valor jurídico protegido pela outra infração. Quer dizer, a infração à ordem pública do regime sancionatório geral também representa uma lesão à ordem interna do regime disciplinar, ainda que em menor grau, porque a ineficiência administrativa abala a imagem do setor público, produz desgaste e descrédito institucional, enquanto a infração à ordem interna implica, entre outras coisas, no restabelecimento do direito violado e na preservação da ordem pública, embora também em menor medida ${ }^{32}$.

Sendo assim, não se poderia traçar diferenças gritantes entre o regime punitivo

\footnotetext{
${ }^{30}$ Conforme WIMMER, Miriam. As relações de sujeição especial na administração pública. Direito Público, Porto Alegre, v. 5, n. 18, p. 31-53, out./dez. 2007.

${ }^{31}$ Expressão utilizada em GARCÍA DE ENTERRÍA, Eduardo; FERNÁNDEZ, Tomáz-Ramón. op. cit., p. 170.

${ }^{32}$ OSÓRIO, Fábio Medina. Direito administrativo sancionador. 2 ed. rev., atual. e ampl. São Paulo: Ed. Revista dos Tribunais, 2005. p. 163-164 e 283-284.
} 
interno e externo, principalmente se tais diferenças visarem a mitigação de princípios constitucionais, que, por sua importância, são indisponíveis e obrigatórios.

É por isso que a diferenciação que se faz entre o regime de supremacia especial e de sujeição especial, principalmente no que se refere à mitigação do princípio da legalidade neste, está perdendo adeptos, na medida em que tal teoria tem sido utilizada para afastar a necessidade de observância das regras e princípios do direito punitivo estatal nas relações especiais e justificar uma atuação administrativa arbitrária, contrariando a finalidade da distinção.

Rafael Munhoz de Mello expressa o atual entendimento a respeito do tema:

A idéia de que há um campo em que a Administração Pública pode agir sem observância no princípio da legalidade é incompatível com o Estado de Direito. Surge a teoria das relações de sujeição especial na Alemanha do final do século XIX, sob a influência de circunstâncias políticas da época. Mas um verdadeiro Estado de Direito a idéia não pode prosperar. Assim é que na própria Alemanha, após o advento da Constituição de Bonn, doutrina e jurisprudência foram paulatinamente rechaçando o instituto das relações de sujeição especial, considerado como "uma lacuna do Estado de Direito". Em outros países o recurso indiscriminado à figura das relações de especial sujeição, que justificou atuações arbitrárias da Administração Pública, faz com que a doutrina analise o tema com cautela e reserva, havendo referências à "sombra del fantasma de las 'relaciones especiales de sujecion"." ${ }^{33}$

Por isso é que também entendemos que tal doutrina se revela incompatível com o atual ordenamento jurídico pátrio, não podendo haver diferença de tratamento entre os cidadãos sujeitos à relação especial e os demais administrados.

O que pode haver é a adaptação dos princípios e normas sancionatórios gerais ao âmbito da relação especial de sujeição, de forma que haja compatibilidade com as características do poder disciplinar, até porque é essa maleabilidade que garante o acompanhamento do dinamismo da realidade, conferindo justiça e equilíbrio ao ordenamento jurídico e sua aplicação, conforme destaca Fábio Medina Osório:

Desse modo, compreende-se que, efetivamente, há uma razão de ser para atribuir à infrações disciplinares determinadas características, peculiares e requisitos específicos, sem que, não obstante, se desvirtue sua natureza de sanção administrativa, sendo-lhes aplicáveis os princípios constitucionais regentes do Direito Administrativo Sancionador. Diga-se, ademais, que a variação do conteúdo desses princípios não significa, por seu grau e

\footnotetext{
${ }^{33}$ MELLO, Rafael Munhoz de. Princípios constitucionais de direito administrativo sancionar: as sanções administrativas à luz da Constituição Federal de 1988. São Paulo: Malheiros Ed., 2007. p. 160.
} 
intensidade mínimos, o reconhecimento de princípios diversos ou o chancelamento de regimes jurídicos distintos. É normal, como se disse, que um princípio constitucional apresente algumas diferenças quando incida sobre suportes fáticos e normativos distintos, fenômeno perfeitamente compreensível no âmbito jurídico, dado que decorre do próprio processo de interpretação. De um princípio não resultam soluções uniformes para casos e situações distintas; seria absurdo que assim ocorresse, até por uma questão de operacionalizar corretamente a igualdade das pessoas na lei. ${ }^{34}$

Portanto, a distinção de características entre os regimes punitivos não podem servir de justificativa para se violar princípios constitucionais punitivos que existem para serem aplicados, inclusive, nas relações entre particulares.

As garantias fundamentais dos agentes públicos devem ser respeitadas assim como são as dos demais administrados. Não é por outro motivo que, pela construção moderna de relação de especial sujeição, são toleradas apenas as restrições constitucionalmente previstas $^{35}$.

\subsection{Ilícito administrativo}

O ilícito administrativo é um instituto que aparece em diversas áreas do direito, pois sua essência não se altera conforme a sua disposição ${ }^{36}$.

Ilícito é o comportamento contrário a um dever ou consoante a uma proibição normativa, pressuposto de uma sanção. "É a conduta contrária à devida", é o comportamento antijurídico ${ }^{37}$.

Seriam elementos do ato ilícito: "o ato ou omissão humanos, a infringência à norma legal do ramo considerado, o dano e a responsabilidade; em suma, alguém causando desequilíbrio na ordem natural-legal da sociedade e, pelo seu restabelecimento, devendo

\footnotetext{
${ }^{34}$ OSÓRIO, Fábio Medina. Teoria da improbidade administrativa: má gestão pública, corrupção e ineficiência. São Paulo: Ed. Revista dos Tribunais, 2005. p. 156, nota de rodapé 71.

${ }^{35}$ Nesse sentido: NETTO, Luísa Cristina Pinto e. A contratualização da função pública. Belo Horizonte: Del Rey, 2005. p. 221.

${ }^{36}$ ARAÚJO, Edmir Netto de. O ilícito administrativo e o seu processo. São Paulo: Ed. Revista dos Tribunais, 1994. p. 23. HUNGRIA, Nelson. Ilícito administrativo e ilícito penal. Revista de Direito Administrativo, Seleção histórica, Rio de Janeiro, p. 15-21, 1945-1995.

${ }^{37}$ OLIVEIRA, Regis Fernandes de. Infrações e sanções administrativas. 2. ed., rev., atual. e ampl. São Paulo: Ed. Revista dos Tribunais, 2005. p. 17.
} 
responder",38.

No âmbito do poder disciplinar, o ilícito consiste no ato ou omissão que infringe dever contido na respectiva lei funcional ou se enquadra em tipificação contida na mesma. A infração tem que resultar de inobservância de deveres vinculados às atribuições do cargo, função ou emprego ${ }^{39}$ e "se revelar nociva ao bem jurídico e aos valores especialmente tutelados pela norma repressiva" ${ }^{\prime 40}$.

Esclarece, entretanto, Marcello Caetano, que o ilícito não precisa estar ligado exclusivamente à violação dos deveres decorrentes da função exercida pelo funcionário público, pois a ofensa dos deveres jurídicos e morais aos quais os cidadãos em geral estão sujeitos pode constituir infração disciplinar se puder afetar a relação do sujeito que a praticou com a Administração Pública, relação esta resultante do vínculo que especialmente os liga $^{41}$.

A obrigação de observar os deveres impostos pelo ordenamento jurídico se inicia com o início do desempenho da função pelo agente, quer dizer, assim que iniciar o seu vínculo com a Administração Pública.

O dano pode ou não integrar a estrutura do ilícito, dependendo da tipificação, assim como no direito penal, em que há os ilícitos materiais e os ilícitos formais. Em geral, a infração disciplinar é formal.

\subsection{Sanção administrativa}

A sanção, para Hans Kelsen, tem função primordial no sistema jurídico, pois é ela que caracteriza o preceito normativo, quer dizer, ela é elemento necessário da norma. $\mathrm{O}$ comportamento é prescrito e a conduta oposta é pressuposto para uma sanção. A sanção motiva os indivíduos a praticarem ou não determinadas condutas, "na medida em que o desejo de evitar a sanção intervém como motivo na produção desta conduta"42 ${ }^{\text {. Para ele, o }}$

\footnotetext{
${ }^{38}$ ARAÚJO, Edmir Netto de. O ilícito administrativo e o seu processo, cit., p. 23.

${ }^{39}$ MEDAUAR, Odete. Direito administrativo moderno. 12. ed. rev. atual. e ampl. São Paulo: Ed. Revista dos Tribunais, 2008. p. 303.

${ }^{40}$ OSÓRIO, Fábio Medina. Direito administrativo sancionador, cit., p. 323.

${ }^{41}$ CAETANO, Marcello. Manual de direito administrativo. 10. ed. 6 reimp. Coimbra: Livr. Almedina, 1999. v. 2, p. 807-808.

${ }^{42}$ KELSEN, Hans. Teoria pura do direito. Trad. João Baptista Machado. 6 ed. Coimbra: Armênio Amado, 1984. p. 49 e 62-63.
} 
conceito de ilícito e sanção são correlativos. "A sanção é conseqüência do ilícito; o ilícito (ou delito) é um pressuposto da sanção."43

Sanção, no sentido genérico, indica qualquer meio pelo qual o legislador se vale para assegurar a eficácia da norma. Em sentido específico e técnico, seria a consequência danosa que o legislador liga ao fato indesejado como meio de repor a ordem jurídica turbada, imposta àqueles que violam a norma; é o meio indireto pelo qual o legislador obtém a observância da lei ${ }^{44}$.

“A sanção é uma instituição que ajuda a construir e manter o mundo social ao produzir categorias comuns, compartilhadas pela maioria e que permitem aos indivíduos se entender uns com os outros", direciona a conduta das pessoas, comunicando informações acerca das relações sociais e de vários outros assuntos tangenciais, organiza e educa a mentalidade moral, política e social das pessoas ${ }^{45}$.

Não há diferença ontológica entre o ilícito penal e o ilícito administrativo, não há diferença substancial entre a sanção penal e a sanção administrativa. Trata-se da consequência jurídica imposta, por lei, àquele que cometeu ilícito. Trata-se de um mal, um castigo, que implica um juízo de provação de direitos, imposição de deveres e restrição de liberdades ${ }^{46}$. O legislador, a fim de afastar a realização de condutas indesejadas, prescreveas em normas para que não sejam cometidas e, para animar sua não realização, prescreve consequências não desejadas por aquele que cometeu a infração. Neste sentido, explica Rafael Munhoz de Mello:

É evidente que a inobservância das condutas impostas pelas normas não é situação desejada, sendo certo que todo ordenamento normativo tem por objetivo conformar condutas. Se nenhuma conseqüência decorresse da violação da norma, as ordens normativas não teriam qualquer sentido ou utilidade, pois sua eficácia dependeria unicamente da adoção voluntária da conduta estabelecida normativamente. É preciso, pois, que a violação tenha conseqüência, que o ordenamento preveja uma resposta ao descumprimento da norma. Tal resposta é a sanção. ${ }^{47}$

\footnotetext{
${ }^{43}$ KELSEN, Hans. op. cit., p. 68.

${ }^{44}$ Conforme ZANOBINI, Guido. Le sanzioni amministrative, cit., p. 1-2. CRETELLA JÚNIOR, José. Prática do processo administrativo. 6. ed. rev. e atual. São Paulo: Ed. Revista dos Tribunais, 2008. p. 84-85.

${ }^{45}$ FALCÓN Y TELLA, María José; FALCÓN Y TELLA, Fernando. Fundamento e finalidade da sanção: existe um direito de castigar? Trad. AVENA, Claudia de Miranda, revisão de Flávio Luiz Gomes. São Paulo: Ed. Revista dos Tribunais, 2008. p. 91.

${ }^{46}$ OSÓRIO, Fábio Medina. Direito administrativo sancionador, cit., p. 97.

${ }^{47}$ MELLO, Rafael Munhoz de. op. cit., p. 36.
} 
Assim como ocorre com as prescrições dos ilícitos em geral, a aplicação da pena deve observar os princípios da legalidade, da anterioridade e da tipicidade. Fábio Medina Osório ensina que, assim como ocorre com as infrações, deve haver um mínimo de certeza e previsibilidade nos conteúdos descritivos da sanção. Não haveria óbice para que, em casos excepcionais e justificados, à luz de critérios razoáveis, a Administração Pública fixasse as penas, desde que a lei fixasse o conteúdo básico e fundamental delas ou estabelecesse os limites mínimos e máximo delas ${ }^{48}$. Marçal Justen Filho observa que tanto a ausência de previsão da sanção por lei quanto a inexistência de padrões delimitadores de sua aplicação afiguram-se inconstitucionais ${ }^{49}$. Odete Medauar acrescenta que a sanção tem que estar associada a uma infração determinada, a fim de que não se viole o princípio da legalidade ${ }^{50}$. Marcelo Madureira Prates afirma, por sua vez, que deve haver graduação na previsão das sanções, sob pena de se violar a igualdade, impessoalidade e proporcionalidade $^{51}$. Já Heraldo Garcia Vitta ressalta que a utilização, na prescrição do ilícito, de conceitos jurídicos indeterminados reforça a necessidade de existência de respectivas sanções taxativas ${ }^{52}$.

As penalidades administrativas disciplinares existentes são: advertência por escrito (repreensão), suspensão, multa, destituição de função comissionada ou de cargo em comissão, cassação de aposentadoria ou disponibilidade, demissão e demissão a bem do serviço público.

A aplicação da sanção pode ocorrer mesmo após o funcionário deixar sua atividade ou ter perdido a qualidade de agente; isso não o isenta da sanção, pois a importância da pena ultrapassa aquela relação então existente e se estende àquelas que podem surgir de um novo vínculo. É de interesse do Estado, e da coletividade, que conste o registro da sanção no assento do agente público, pois isso pode impedir ou, pelo menos, alertar a Administração Pública em eventual e futuro processo de seleção, podendo, tal advertência, ser considerada, também, na hipótese de ele vir a sofrer novo processo administrativo na nova função exercida.

\footnotetext{
${ }^{48}$ OSÓRIO, Fábio Medina. Direito administrativo sancionador, cit., p. 321-322.

${ }^{49}$ JUSTEN FILHO, Marçal. op. cit., p. 856.

${ }^{50}$ MEDAUAR, Odete. op. cit., p. 305.

${ }^{51}$ PRATES, Marcelo Madureira. op. cit., p. 113.

${ }^{52}$ VITTA, Heraldo Garcia. A sanção no direito administrativo. São Paulo: Malheiros Ed., 2003. p. 93.
} 


\section{CAPÍTULO 1. EFICIÊNCIA}

\subsection{Introdução da eficiência no ordenamento jurídico pátrio}

A eficiência, como princípio da Administração Pública, foi ineditamente introduzida no texto constitucional por meio da Emenda Constitucional n ${ }^{\circ} 19$, de 4 de julho de 1998, como fruto do contexto do momento.

\subsubsection{Contexto das reformas administrativas}

Com as revoluções libertárias, ocorridas no fim do século XVIII, que acarretaram a vinculação do Estado aos limites da lei e a proteção aos direitos individuais, o Estado absolutista se enfraqueceu, viabilizando, assim, a liberdade almejada pelo povo, antes inexistente.

Nesse rumo, houve o afastamento do Estado da ingerência dos interesses privados, vigorando, à época, o denominado Estado "mínimo", que se restringia apenas às questões de segurança e justiça, deixando o resto (social, econômico e religioso) por conta dos próprios particulares, agindo, assim, de acordo com o exato interesse da burguesia.

A Revolução Industrial e os avanços tecnológicos científicos, ocorridos nos séculos XIX e XX, criaram uma nova ordem, caracterizada, principalmente, pelo abismo econômico e social formado entre a burguesia e o proletariado, pelas injustiças e tensões sociais que se estabeleceram, agravadas pelo abstencionismo do Estado.

A fim de se restabelecer o equilíbrio e amenizar as tensões da época, fez-se imprescindível que o Estado suprisse as novas necessidades sociais, já que muitas delas não eram atendidas pela iniciativa privada, porque a ela não interessavam. Fazia-se necessário compatibilizar em um mesmo sistema o capitalismo, como forma de produção, e o bemestar social, proporcionando a igualdade material (igualdade na oportunidade), até então garantida apenas formalmente.

Consagraram-se, assim, os direitos sociais e econômicos, ocorrendo, consequentemente, o aumento das atividades estatais que visaram suprir a defasagem 
existente entre as camadas sociais. Alterou-se a natureza da atividade da Administração Pública, passando a deter um caráter mais social com controle do domínio econômico; é o denominado Estado Social.

A partir da Primeira Guerra Mundial e da Grande Depressão que se seguiu, o papel do Estado no âmbito social e econômico tomou enormes proporções com vistas a promover a recuperação da crise. O intervencionismo do Estado na economia acabou por conduzi-lo a desenvolver atividades da mesma natureza daquelas desenvolvidas pelos particulares por conta da necessidade de se aumentar a produção nacional e produzir armamentos. Tal processo de ampliação das atividades estatais continuou mesmo após o advento da Segunda Guerra Mundial, visando solucionar os problemas sociais e reforçar ao máximo a segurança nacional e teve como consequência uma incontrolada multiplicação dos tributos ${ }^{53}$.

O advento da II Guerra Mundial iria estimular ainda mais a atitude intervencionista do Estado. Assumindo amplamente o encargo de assegurar a prestação dos serviços fundamentais a todos os indivíduos, o Estado vai ampliando sua esfera de ação. E a necessidade de controlar os recursos sociais e obter o máximo proveito com o menor desperdício, para fazer face às emergências da guerra, leva a ação estatal a todos os campos da vida social, não havendo mais qualquer área interdita à intervenção do Estado. Terminada a guerra ocorre ainda um avanço maior do intervencionismo, pois inúmeras necessidades novas impõem a iniciativa do Estado em vários setores: na restauração dos meios de produção, na reconstrução das cidades, na readaptação das pessoas à vida social, bem como no financiamento de estudos e projetos, sugeridos pelo desenvolvimento técnico e científico registrado durante a guerra. ${ }^{54}$

Consolida-se, então, o Estado Social, também chamado Estado-Providência, e o Poder Executivo se torna mais forte. A avocação de diversas atividades, por outro lado, acarretou o agigantamento da máquina administrativa acompanhado pela sua rigidez e pela oneração da carga tributária, a fim de se manter tal organização, o que implicou em obstáculo ao desenvolvimento normal da economia ${ }^{55}$. O rígido modelo de administração burocrática, surgido no Estado Liberal, como forma de combater a corrupção e o nepotismo patrimonialista, não se adapta às novas funções do Estado, pois limita sua atuação de forma compatível com as necessidades, gerando insatisfação e desconfiança social.

\footnotetext{
${ }^{53}$ Conforme MOREIRA NETO, Diogo de Figueiredo. Mutações nos serviços públicos. In: WAGNER JUNIOR, Luiz Guilherme Costa (Coord.). Direito público: estudos em homenagem ao professor Adilson Abreu Dallari. Belo Horizonte: Del Rey, 2004. p. 213-214.

${ }^{54}$ DALLARI, Dalmo de Abreu. Elementos de teoria geral do Estado. 19. ed. atual. São Paulo: Saraiva, 1995. p. 237.

${ }^{55}$ Conforme RAMOS, Dora Maria de Oliveira. op. cit., p. 26.
} 
Foi nesse contexto que, no Brasil, foi expedido o Decreto-Lei $\mathrm{n}^{\circ} 201$, de 27 de fevereiro de 1967, que visou melhor adequar a máquina administrativa a um modelo que se coadunasse com o desenvolvimento social e econômico que se pretendia alcançar, mas que era embaraçado pela estrutura rígida de hierarquia e de controle nos meios de atuação do modelo burocrático. $\mathrm{Na}$ mensagem presidencial que acompanhou referida norma, foi possível verificar que seu propósito foi “obter que o setor público possa operar com a eficiência da emprêsa privada" ${ }^{, 56}$.

No entanto, os compromissos assumidos pelo Estado eram tão grandes que "nem a norma jurídica acompanhou as necessidades da administração, nem a administração conseguiu equacionar suas necessidades para postular novas normas jurídicas adequadas às exigências sociais",57.

O final da Guerra Fria, a decadência dos regimes comunistas e socialistas e, consequentemente, da bipolaridade que predominou durante boa parte do século $\mathrm{XX}$ contribuíram para a afirmação do regime capitalista como o mais eficiente. "Nesta nova realidade, o espírito do capitalismo encontrou terreno fértil para o seu desenvolvimento, pois agora poucos ousariam duvidar de sua eficiência, principalmente após serem colocadas às escâncaras as fragilidades dos países que ousaram recusar a sua adoção." 58

Assim, houve uma abertura de espaço para a iniciativa privada como uma forma de solucionar as mazelas da atividade administrativa. Neste contexto é que houve o processo de desestatização e de fuga para o regime privado, de abertura do mercado e de flexibilização, com redução do Estado e limitação de sua intervenção no mercado.

O Brasil, entretanto, na mesma época em que os países desenvolvidos caminhavam para a redução do intervencionismo do Estado, porque recém-saído do regime de ditadura militar e por força da "embriaguez libertária decorrente do término do regime de exceção", se excedeu na atuação provedora do Estado ${ }^{59}$, vivendo movimento inverso do resto do mundo. Consagrou um enrijecimento burocrático extremo, na tentativa de libertar o país das mazelas que preponderavam ${ }^{60}$ e manteve uma atuação compatível com o Estado-

\footnotetext{
${ }^{56}$ Conforme DIAS, José de Nazaré Teixeira. A reforma administrativa de 1967. Rio de Janeiro: Fundação Getúlio Vargas, 1968. p. 54. (Cadernos de Administração Pública n. 73).

${ }^{57}$ Id. Ibid., p. 43.

${ }^{58}$ Nesse sentido: DIAS, Jefferson Aparecido. Princípio da eficiência \& moralidade administrativa. 2. ed. Curitiba: Juruá, 2008. p. 20-21.

${ }^{59}$ MORAIS, Dalton Santos. Os custos da atividade administrativa e o princípio da eficiência. Revista de Direito Administrativo, Rio de Janeiro, n. 237, p. 165-196, jul./set. 2004.

${ }^{60}$ PEREIRA, Luiz Carlos Bresser. op. cit., p. 42-43.
} 
Providência.

O Estado do Bem-estar é um Estado mais atuante; ele não se limita a manter a ordem pública, mas desenvolve inúmeras atividades na área da saúde, educação, assistência e previdência social, cultura, sempre com o objetivo de promover o bem estar coletivo. Nesse caso, o Direito Administrativo amplia o seu conteúdo, porque cresce a máquina estatal e amplia o campo de incidência da burocracia administrativa. O próprio conceito de serviço público amplia-se, pois o Estado assume e submete a regime jurídico publicístico atividades antes reservadas aos particulares. Além disso, a substituição do Estado liberal, baseado na liberdade de iniciativa, pelo Estado-Providência ampliou, em muito, a atuação estatal no domínio econômico, criando novos instrumentos de ação do poder público, quer para disciplinar e fiscalizar a iniciativa privada, com base no poder de polícia do Estado, quer para exercer atividade econômica, diretamente na qualidade de empresário. ${ }^{61}$

Assim, a Constituição Federal de 1988 ignorou completamente as novas tendências e seguiu no sentido de "primeiro, completar a revolução burocrática, para, depois, pensar nos princípios da moderna administração pública"62. "Daí porque, inevitavelmente, teve que receber um número considerável de emendas, para ajustar-se à realidade emergente.”63

A assunção das complexas tarefas sociais definidas pela Constituição de 1988 não impediu que finalmente o ordenamento jurídico brasileiro sucumbisse à influência da nova onda. A racionalização do governo, mediante a introdução de elementos técnicos e altamente especializados que auxiliassem o governo, era tendência reconhecida por todos ${ }^{64}$. As inúmeras emendas à Constituição Federal visaram eliminar os obstáculos à adoção de um regime que valorizasse uma redução do papel do Estado, visando, entre outros, a redução dos gastos públicos ${ }^{65}$.

O Estado "libera-se da prestação de inúmeras atividades, deixando-as nas mãos da iniciativa privada. Em conseqüência, ele diminui o tamanho do seu aparelho administrativo" e assume a posição de planejamento, regulação, controle, subsídio e incentivo da iniciativa privada de interesse público, propiciando que o indivíduo se

\footnotetext{
${ }^{61}$ DI PIETRO, Maria Sylvia Zanella. Direito administrativo, cit., p. 3.

${ }^{62}$ PEREIRA, Luiz Carlos Bresser. Crise econômica e reforma do Estado no Brasil: para uma nova interpretação da América Latina. São Paulo: Ed. 34, 1996. p. 275.

${ }^{63}$ Conforme DALLARI, Adilson Abreu. Privatização, eficiência e responsabilidade. In: MOREIRA NETO, Diogo de Figueiredo (Coord.). Uma avaliação das tendências contemporâneas do Direito Administrativo. Rio de Janeiro: Renovar, 2003. p. 218.

${ }^{64}$ DALLARI, Dalmo de Abreu. op. cit., p. 212.

${ }^{65}$ Conforme MORAES, Germana de Oliveira. Considerações gerais sobre a reforma administrativa - Emenda Constitucional 19, de 04.06.1998. Revista Tributária e de Finanças Públicas, São Paulo, n. 34, p. 169-175, 2000 .
} 
desenvolva livremente e igualmente dentro da sociedade ${ }^{66}$. Ou seja, surge a concepção de Estado Subsidiário, que é menor e, sobretudo, mais eficiente, "buscando concentrar-se em necessidades vitais da sociedade aberta, em moldes que até mesmo se configuram nos países desenvolvidos ${ }^{\prime 67}$. Desta forma, a atividade estatal se concentra apenas nas funções de auxílio, coordenação e fomento, sem impedir e estimulando a iniciativa daqueles que compõem a sociedade.

Paralelamente a isso, o sucesso do capitalismo fez com que a sociedade passasse a ser muito mais exigente, exigindo mais também do Estado ${ }^{68}$, o que também contribuiu para a convicção de que a forma gerencial de administração era a solução para os problemas da Administração Pública.

Foi esse o contexto da reforma implementada por meio das emendas à Constituição Federal, entre elas a Emenda Constitucional nº 19/98.

\subsubsection{Emenda Constitucional $n^{\circ} 19 / 98$}

A Emenda Constitucional 19/98 foi precedida pelo Plano Diretor de Reforma do Aparelho Estatal, no qual a Constituição Federal de 1988 foi tida como retrocesso burocrático por ter engessado o aparelho estatal ao impor a mesma estrutura rígida tanto para os serviços do Estado como para o núcleo estratégico do Estado, tanto para a Administração Direta como para a Indireta, por implementar um regime único para os servidores públicos e por retirar do Poder Executivo sua autonomia para tratar de sua própria estrutura.

O Plano Diretor pretendeu instaurar uma administração ágil e com maior grau de autonomia, capaz de enfrentar os desafios de um Estado moderno, que acabara de sair da estagnação econômica e, para alcançar tal intento, considerou imprescindível a alteração das regras constantes do ordenamento jurídico vigente. Para tanto, considerou necessária a publicação de diversas emendas constitucionais. Tais emendas visavam a introdução do

\footnotetext{
${ }^{66}$ DI PIETRO, Maria Sylvia Zanella. Discricionariedade administrativa na Constituição de 1988. 2. ed. 4. reimpr. São Paulo: Atlas, 2007. p. 53.

${ }^{67}$ TÁCITO, Caio. Transformações do direito administrativo. Revista de Direito Administrativo, Rio de Janeiro, n. 214, p. 27-34, out./dez. 1998.

${ }^{68}$ Conforme MODESTO, Paulo. Notas para um debate sobre o princípio constitucional da eficiência. Revista Diálogo Jurídico, Salvador, v. 1, n. 2, maio, 2001. Disponível em: <http://www.direitopublico.com.br>. Acesso em: 29 jan. 2009.
} 
modelo gerencial para resolver a crise do Estado, valendo-se de métodos privados de administração empresarial, que focam o resultado final da ação administrativa, e não o seu processo, como a burocracia. Menciona o plano: “Os resultados da ação do Estado são considerados bons não porque os processos administrativos estão sob controle e são seguros, como quer a administração pública burocrática, mas porque as necessidades do cidadão-cliente estão sendo atendidas" 69 .

Assim, a reforma visou "reforçar a capacidade de governo do Estado, através da transição programada de um tipo de administração pública burocrática (rígida e ineficiente, voltada para si própria e para o controle interno) para uma administração pública gerencial (flexível e eficiente, voltada para o atendimento da cidadania)" ${ }^{\text {,70. }}$.

No que se refere aos recursos humanos, dos quais dispõe o Estado para a realização de suas finalidades, o Plano Diretor de Reforma do Aparelho Estatal apontou vários problemas estruturais (como deficiências na forma de tratamento dos recursos humanos, distorção na distribuição de servidores, falta de rotinização dos concursos a possibilitar contratação constante, falta de amplitude de remuneração dentro de uma mesma carreira que motivasse a ascensão, etc.) e reconheceu a falta de um sistema de incentivos para o profissional, de uma política orgânica de formação, capacitação permanente e de remuneração condizente com a valorização do exercício da função pública. Adicionou a isso tudo uma indevida falta de autonomia dos administradores públicos para decidir questões relacionadas com recursos humanos, materiais e finanças, imprescindível para a fluidez do exercício das funções.

O Plano Diretor afirmou ser prejudicial a aplicação indiscriminada do instituto da estabilidade e, por conta disso, é que a Emenda Constitucional $n^{\circ}$ 19/98 acabou flexibilizando o instituto da estabilidade, mediante a possibilidade de exoneração após resultado negativo em avaliação periódica, e alterando o prazo para a aquisição da estabilidade, que passou de dois para três anos. A referida emenda passou a prever, ainda, a necessidade de avaliação de desempenho no curso do estágio probatório como condição para aquisição da estabilidade.

Prevê, a emenda, que deverá haver critérios e garantias especiais para a perda do

\footnotetext{
${ }^{69}$ PLANO Diretor da Reforma do Estado. Brasília, nov. 1995. Bresser-Pereira Website. Disponível em: $<$ http://www.bresserpereira.org.br/Documents/MARE/PlanoDiretor/planodiretor.pdf>. Acesso em: 21 out. 2008.

${ }^{70}$ SANTOS, Alvacir Correa dos. Princípio da eficiência da administração pública. São Paulo: LTr, 2003. p. 164.
} 
cargo pelo servidor público estável que, por força do cargo exercido, desenvolva atividades exclusivas de Estado. Segundo a justificativa da emenda, tal norma trata da regulamentação da estabilidade de forma rígida para as carreiras que desenvolvam funções exclusivas de Estado, e, de forma mais flexível, para os demais funcionários.

Houve a extinção do regime unicista, o que conferiu prerrogativas próprias da estabilidade apenas a determinada categoria de funcionários.

Apesar de a eficiência ter sido a base de fundamentação de toda reforma ${ }^{71}$, não constou do Plano Diretor qualquer alusão à inclusão da eficiência como princípio administrativo no texto constitucional. No entanto, ele foi acrescentado ao lado dos demais princípios que permaneceram inalterados.

O projeto da emenda fazia alusão à expressão “qualidade do serviço público", tendo havido, no Senado, a alteração para a expressão "eficiência". Esse fato é encarado, por alguns, como comprovação de que as ideias privatísticas que vigoravam durante toda a reforma, conferindo-lhe conotação econômica, não podem ser utilizadas na interpretação deste princípio, ainda mais porque sua previsão nem mesmo constou do Plano Diretor ou do projeto da Emenda Constitucional ${ }^{72}$.

Alvacir Correa dos Santos assim entende:

Saliente-se que mesmo que tenha sido a intenção dos reformadores da Constituição (via Emenda Constitucional 19/98) introduzir no caput do art. 37 da Constituição a figura da eficiência à moda da administração empresarial privada, isso em nada altera o significado diante da Administração Pública, pois, em qualquer organização (seja pública ou privada) deve-se sempre buscar o melhor resultado com o menor esforço ou custo possíveis, com a diferença de que a procura pelo menor gasto com o maior lucro pode ser livremente perseguida pelo administrador privado, desde que não encontre vedação legal em sentido contrário, ao passo que, no âmbito da Administração Pública, a busca será pelo menor gasto com a maior produtividade no atendimento do interesse público (aqui residindo efetivamente o lucro do ato administrativo), devendo tal busca se dar somente mediante previsão legal. ${ }^{73}$

Não há, entretanto, como afastar completamente as ideias que predominavam quando da introdução da emenda constitucional, sendo certo, ainda, que tais ideias devem

\footnotetext{
${ }^{71}$ Conforme DIAS, Jefferson Aparecido. op. cit., p. 72.

${ }^{72}$ Nesse sentido: GUIMARÃES, Daniel Serra Azul. O princípio geral da eficiência na administração pública. 2007. Dissertação (Mestrado) - Pontifícia Universidade Católica de São Paulo, São Paulo, 2007. p. 83-84 e 94 e CHICÓSKI, Davi. O princípio da eficiência e o procedimento administrativo. Revista de Direito Administrativo, Rio de Janeiro, n. 237, p. 93-118, jul./set. 2004.

${ }^{73}$ SANTOS, Alvacir Correa dos. op. cit., p. 18.
} 
ser adaptadas ao sistema vigente na Administração Pública há longas décadas, até porque ela conta com peculiaridades que não se encontram no sistema privado.

A introdução da eficiência no ordenamento jurídico pretendeu, sem dúvida, estabelecer uma nova forma de administração, já que a que vigorava até então não vinha se mostrando apta a dar bons resultados, mas isso não precisa necessariamente desvirtuar ou alterar o sistema atualmente existente, mas sim "revigorar o movimento de atualização de direito público, para mantê-lo dominante no Estado Democrático e Social"74, até porque, lembra Maria Sylvia Zanella Di Pietro: "Por mais que se idealize a fuga do direito administrativo, ela nunca poderá ser integral, porque, mesmo quando se socorre de institutos do direito privado, tais normas são parcialmente derrogadas pelo direito público"75.

A utilização de mecanismos do sistema privado existe porque o direito administrativo ainda não conseguiu desenvolver técnicas que acompanhem as novas realidades. Se desenvolvidas tais técnicas, verificar-se-á que a opção não seria a manutenção do sistema ora vigorante e tampouco a aplicação de um sistema importado das relações privadas, mas sim, o aproveitamento do que os dois ramos têm de melhor, "propondo uma mudança de paradigmas capaz de estabelecer um diálogo fecundo que permita desenvolver novos padrões conceituais a partir dos quais seja possível apreender e orientar as inevitáveis transformações do setor público,"76.

\subsubsection{Eficiência na Ciência da Administração}

\subsubsection{Direito Administrativo e Ciência da Administração}

Com a sujeição do Estado às leis, após as revoluções libertárias do final do século XVIII, a Administração Pública passou a ser estudada com o enfoque exclusivamente jurídico, deixando-se de lado o estudo da Ciência da Administração como ramo autônomo.

\footnotetext{
${ }^{74}$ MODESTO, Paulo. op. cit.

${ }^{75}$ DI PIETRO, Maria Sylvia Zanella. Inovações no direito administrativo. Interesse Público, Porto Alegre, $\mathrm{n}$. 30, p. 39-55, mar./abr. 2005.

${ }^{76}$ Conforme Prats I Catalá, que acrescenta que, na verdade, o paradigma tradicional do Direito Administrativo e o paradigma gerencial possuem coincidência de pressupostos, valores, problemas e métodos. PRATS I CATALÁ, Joan. Direito e gerenciamento nas administrações públicas - notas sobre a crise e renovação dos respectivos paradigmas. Revista do Serviço Público, ano. 47, v. 120, n. 2, p. 23-45, maio/ago. 1996.
} 
No entanto, tal estudo foi retomado com o término da Segunda Guerra Mundial, na medida em que se fez necessária a melhoria no desempenho administrativo em virtude do aumento das atribuições do Estado ${ }^{77}$. Nesse momento, houve a necessidade de se desenvolver o estudo do aspecto jurídico e político dessa ingerência estatal, bem como da organização e gerência de suas finanças públicas. O problema era enquadrar tal objeto de estudo dentro de uma das ciências.

Várias correntes e escolas doutrinárias surgiram, umas que colocavam o estudo da Ciência da Administração dentro do estudo do Direito Administrativo, outras que faziam sua separação e outras, ainda, que traziam sua absoluta independência. Até mesmo o conteúdo abrangido pela ciência administrativa era incerto. Alguns entendiam que abrangia a parte política, outros, a parte jurídica, outros, as partes social, econômica, técnicomaterial, só algumas delas ou todas juntas, etc. ${ }^{78}$

Ainda não é fácil precisar onde se situa o estudo da organização e ação da Administração Pública. Sabe-se, entretanto, que a Ciência da Administração Pública estuda os aspectos não normativos da atividade estatal; estuda os melhores métodos de organização e de gestão da Administração Pública e os fatores técnicos e humanos que os comandam $^{79}$. Ou seja, busca os melhores métodos e regras para se conseguir a realização da finalidade desejada por meio da atuação administrativa.

Este objetivo não é buscado apenas no âmbito estatal. A racionalização da organização, do trabalho, da produção e das finanças, aliada à eficiência na atuação e no resultado é objetivo primordial em qualquer empresa privada, tendo, nesta área, sido desenvolvidos destacados trabalhos de autoria de Fayol e Taylor, que se dedicaram ao estudo de tais temas. Tais estudos enfocam os princípios da racionalização com base nas questões políticas, sociológicas, econômicas e técnicas.

A escolha dessas técnicas, desenvolvidas pela Ciência da Administração, a serem consagradas nas normas, segundo Marcello Caetano, é afeta à política administrativa, mas sua disciplina interessaria ao jurista para que ele pudesse apreender as razões, as intenções e o fim da lei, já que o direito fornece apenas o aspecto exterior e formal da organização e da

\footnotetext{
${ }^{77}$ Nesse sentido: MEDAUAR, Odete. op. cit., p. 39.

${ }^{78}$ A propósito, ver MELLO, Oswaldo Aranha Bandeira de. Princípios gerais de direito administrativo: introdução. 3. ed. São Paulo: Malheiros Ed., 2007. v. 1, p. 78-127.

${ }^{79}$ RIVERO, Jean. Direito administrativo. Trad. Rogério Ehrhardt Soares. Coimbra: Livr. Almedina, 1981. p. 24.
} 
atividade administrativa, que as suas normas estruturam e disciplinam ${ }^{80}$.

O direito administrativo nada mais seria do que a transposição, em forma jurídica, das opções fundamentais e técnicas quanto aos métodos de construção e de gestão do organismo administrativo que foram desenvolvidas na respectiva ciência ${ }^{81}$.

Edmir Netto de Araújo assim sintetiza a questão: "No caso da Administração Pública, a chamada Ciência da Administração a estuda sob os aspectos material e técnico, ao passo que o Direito Administrativo disciplina os aspectos formal e jurídico" ${ }^{, 82}$.

Nesse processo é que se pode concluir que as ideias e conceitos científicos são importantes para o estudo do direito na medida em que incorporados pelo sistema jurídico, estando aí o interesse na Ciência da Administração no presente caso, tendo em vista que o conceito de eficiência foi primeiro desenvolvido neste âmbito científico e apenas posteriormente se incorporou à norma.

\subsubsection{Da importação, pelo Direito Administrativo, da eficiência da Ciência da Administração}

A administração do Estado recebe do ordenamento jurídico a indicação de seus objetivos, mas sua atuação se desenvolve por meio da utilização de numerosas técnicas, que buscam a eficácia na obtenção e no emprego dos recursos adequados para a satisfação das necessidades coletivas.

Nessa atuação existe uma zona metajurídica de atividades política e técnica na qual os órgãos administrativos se movem com liberdade, "consoante as conveniências e as oportunidades inspiram ou as regras de eficácia determinam, ${ }^{, 83}$.

A normatização da eficiência foi extraída dessa atividade metajurídica. A eficiência, como conceito, há muito tempo já existia nos estudos da ciência administrativa. Em linhas gerais, é expressada como a melhor forma de utilização dos recursos disponíveis, isto é, como a otimização da relação meio-fim.

\footnotetext{
${ }^{80}$ CAETANO, Marcello. Manual de direito administrativo. 10. ed. 8. reimp. Coimbra: Livr. Almedina, 2005. v. 1, p. $58-59$ e 60.

${ }^{81}$ RIVERO, Jean. op. cit., p. 24.

${ }^{82}$ ARAÚJO, Edmir Netto de. Do negócio jurídico administrativo. São Paulo: Ed. Revista dos Tribunais, 1992. p. 60.

${ }^{83}$ CAETANO, Marcello. Manual de direito administrativo, cit., v. 1, p. 14-15.
} 
A partir do momento que determinada técnica ou instituto ingressam no ordenamento jurídico, tornam-se obrigatórios, de forma que a análise de seu conteúdo passa a ter importância jurídica na medida em que parametriza uma conduta exigível.

As técnicas existentes na Ciência da Administração, embora importantes, foram desenvolvidas para serem aplicadas no âmbito de mercado privado e, por isso, não podem ser aplicadas ou simplesmente transferidas para o âmbito da Administração Pública. Existem diferenças intransponíveis entre os dois segmentos que merecem ser destacadas. A forma de auferir recursos para a consecução dos seus respectivos fins, por exemplo, é completamente diferente em um e outro setor. No âmbito privado, extraem-se recursos diretamente do mercado, por meio de seus clientes, por meio do processo de intercâmbio entre bens ou serviços por dinheiro, da relação entre oferta e demanda. No âmbito público, a obtenção de recursos se realiza por meio do sistema tributário, no qual nem sempre quem paga é quem vai utilizar o bem ou o serviço; toda a coletividade contribui para o financiamento dos objetivos do Estado ${ }^{84}$.

Observa, ainda, José Afonso da Silva:

Na Administração Pública as condições de eficiência são diferentes porque, em relação aos bens públicos, vale o princípio de não exclusão, isto é, o consumo da parte de um agente econômico não exclui a possibilidade que outros consumam contemporaneamente o mesmo bem; enquanto no caso dos bens privados cada um consome diversas quantidades ao mesmo preço, no caso dos bens públicos (p. ex., a defesa nacional), todos consomem a mesma quantidade atribuindo-lhes valores diferentes. ${ }^{85}$

$\mathrm{Na}$ atividade privada, na qual a finalidade principal é a obtenção de lucro, o instituto da eficiência possui como conteúdo o aumento no número de clientes e a redução do custo da produção. Tais finalidades em nada se relacionam com os objetivos do Estado que visam o alcance do bem comum e uma atuação que garanta o mínimo suficiente para o desenvolvimento das personalidades e a convivência em sociedade, mediante o atendimento de diversas finalidades públicas ramificadas. O critério para a verificação da eficiência pública seria, então, a medida da satisfação dada ao bem comum, isto é, o nível de atendimento dos objetivos constantes do ordenamento jurídico, algo impassível de ser

\footnotetext{
${ }^{84}$ Nesse sentido: SANCHO ROYO, David. Gestión de servicios públicos: estrategias de marketing y calidad. Madrid: Tecnos; Universitat Pompeu Fabra, 1999. p. 24.

${ }^{85}$ SILVA, José Afonso da. Curso de direito constitucional positivo. 32. ed. rev. e atual. (até a Emenda Constitucional n. 57, de 18.12.2008). São Paulo: Malheiros Ed., 2009. p. 672.
} 
mensurado ou avaliado objetivamente ${ }^{86}$.

Assim é que, dadas as diferenças entre os dois segmentos, não se pode concluir em hipótese alguma que o conceito de eficiência foi transplantado integralmente para a norma, não devendo tal instituto ser utilizado na forma e nos termos em que desenvolvido na Ciência da Administração. Nesse sentido, Onofre Alves Batista Júnior:

\begin{abstract}
$\mathrm{Na}$ realidade, o que a Constituição juridicizou foi o Princípio Constitucional da Eficiência, de contornos jurídicos; entretanto, isso não quer dizer que o Direito tenha absorvido in totum as regras técnicas da Ciência da Administração em seu âmago. Os referenciais de eficiência não foram rigidamente juridicizados, e da mesma forma as regras de organização e administração da Ciência da Administração não foram incorporadas tal e qual ao mundo jurídico. ${ }^{87}$
\end{abstract}

Tal autor, com o qual concordamos, registra, ainda, que não é possível a utilização dos princípios e regras de organização e administração desenvolvidos pela Ciência da Administração para traçar o alcance de princípios jurídicos (de eficiência), também porque a própria Ciência da Administração reconhece a impossibilidade de se desenvolver princípios e regras infalíveis ou que tenham vetores exatos ${ }^{88}$.

Por outro lado, não há como afastar a aplicação, ao âmbito público, das conquistas e dos avanços da Ciência da Administração, que podem, sem dúvida, contribuir muito para o aperfeiçoamento da atuação administrativa. Nesse sentido, o ideal é que haja a internalização das ideias privadas, sem que haja a transferência da integralidade desse regime para o âmbito estatal, adequando-o a suas peculiaridades, até porque, é bom lembrar, o direito privado sempre sofre parcial derrogação quando aplicado à Administração Pública.

No caso do instituto da eficiência, uma vez originado da Ciência da Administração, é certo que a acepção que possui naquela área possui relevância para sua compreensão. No entanto, deve-se extrair daquela ciência o aspecto geral que orientou a sua normatização com o fim de conferir o sentido mínimo para o instituto que se tornou jurídico.

Resumindo, uma vez que passa a ser objeto de norma jurídica, a técnica normatizada deixa a ciência administrativa para integrar o direito administrativo. Enquanto isso não

\footnotetext{
${ }^{86}$ Nesse sentido: BATISTA JÚNIOR, Onofre Alves. Princípio constitucional da eficiência administrativa. Belo Horizonte: Mandamentos, 2004. p. 201.

${ }^{87}$ BATISTA JÚNIOR, Onofre Alves. op. cit., p. 417.

${ }^{88}$ Id. Ibid., p. 416-417.
} 
ocorre, é apenas objeto da ciência administrativa. É certo, entretanto, que a diferença não é tão simples, já que a ciência inspira o direito com suas regras e princípios e o direito inspira a ciência, também com suas regras e princípios. Trata-se de uma simbiose. Mas, quando as regras não são incorporadas ao ordenamento por opção política ou técnica e, por conseguinte, não são obrigatórias, não são, também, objeto de estudo do direito administrativo, sendo apenas diretrizes para o comportamento dos agentes, que podem escolher, dentro das melhores técnicas igualmente válidas, aquela que entender a melhor para a solução do caso.

Nesse campo, o que se observa é que, quando não incorporada ao direito, a escolha da técnica nada mais é que opção discricionária dos agentes. Depois de incorporada, passa a ser uma opção parametrizada.

Portanto, não cabe, neste trabalho, eleger a técnica mais eficiente para o desempenho das funções do agente público, cuja não observância acarretaria sua responsabilidade, porque isso se inseriria na Ciência da Administração, e não no Direito Administrativo. O que se pretende é estabelecer o conteúdo mínimo e alguns parâmetros que devem conduzir o exercício da função do agente público na busca da eficiência.

\subsubsection{Conteúdo da eficiência na Ciência da Administração: eficiência, eficácia e efetividade}

Na Ciência da Administração, o conteúdo da eficiência é associado aos conceitos de eficácia e efetividade.

Idalberto Chiavenato explica:

Eficácia é a medida normativa do alcance de resultados, enquanto a eficiência é uma medida normativa da utilização dos recursos nesse processo. Em termos econômicos, a eficácia de uma empresa refere-se à sua capacidade de satisfazer uma necessidade da sociedade por meio do suprimento de seus produtos (bens ou serviços), enquanto a eficiência é uma relação técnica ente entradas e saídas. Nestes termos, a eficiência é uma relação entre custos e benefícios. ${ }^{89}$

\footnotetext{
${ }^{89}$ CHIAVENATO, Idalberto. Introdução à teoria geral da administração. 4. ed. São Paulo: Makron Books
} do Brasil; McGraw-Hill, 1993. p. 237. 
Explica o autor que, quando o administrador se preocupa em fazer corretamente, volta-se para a eficiência, e quando ele se preocupa em verificar se as coisas que estão sendo bem feitas e se são as que realmente devem ser feitas para alcançar determinado resultado, ele se concentra na eficácia. Desta forma, uma organização pode ser eficiente e não eficaz e vice-versa ${ }^{90}$.

Assim, a eficiência se relaciona com os meios e a eficácia se relaciona com os resultados; a efetividade seria a conjugação desses dois fatores, e seria obtida com a adequação de meios e fins ${ }^{91}$.

Onofre Alves Batista Júnior explica que a efetividade seria a manifestação externa à organização daquilo que foi gerado dentro dela, isto é, da eficácia e da eficiência. Tais aspectos se revezam na atuação da Administração Pública com um dinamismo comparável ao movimento de espiral ${ }^{92}$.

Para ele, o princípio da eficiência sem dúvida foi utilizado pelo legislador em seu sentido amplo, isto é, abrangendo o meio e o resultado de uma boa atuação da Administração Pública, para que se possa atingir com efetividade a finalidade de maximização da prossecução do bem comum ${ }^{93}$.

Como dito anteriormente, é necessário se extrair os aspectos gerais do instituto da eficiência estudado na Ciência da Administração e adequá-los ao instituto normatizado. Nesse processo, não há como deixar de fora as noções de meio e resultado, que devem ser devidamente adaptadas à ciência jurídica.

\subsection{Eficiência como princípio constitucional}

Apesar de alguns acharem que a eficiência jamais será um princípio ${ }^{94}$, a Emenda Constitucional $n^{\circ} 19 / 98$ o trouxe expressamente ao texto constitucional e a sua introdução nesta categoria de normas jurídicas não pode passar despercebida ${ }^{95}$.

\footnotetext{
${ }^{90}$ CHIAVENATO, Idalberto. Recursos humanos: o capital humano das organizações. 8. ed. 4. reimpr. São Paulo: Atlas, 2008. p. 41.

${ }^{91}$ RAMOS, Dora Maria de Oliveira. Terceirização na administração pública, cit., p. 136.

${ }^{92}$ BATISTA JÚNIOR, Onofre Alves. op. cit., p. 218-219.

${ }^{93}$ Também nesse sentido: Id. Ibid., p. 662-663 e 217.

${ }^{94}$ LOPES, Mauricio Antonio Ribeiro. Comentários à reforma administrativa: de acordo com as Emendas Constitucionais 18, de 05.02.1988, e 19, de 04.06.1998. São Paulo: Ed. Revista dos Tribunais, 1998. p. 108-109.

${ }^{95}$ Barroso afirma que a interpretação de normas introduzidas na Constituição Federal deve ser realizada sob a lente da Constituição, com filtragem constitucional, de modo a realizar os valores nela consagrados.
} 


\subsubsection{Considerações sobre princípios}

As normas jurídicas são divididas em regras e princípios. Segundo Robert Alexy, a diferença entre os dois é de qualidade, e não de grau ${ }^{96}$.

Nas primeiras, há a descrição de uma hipótese fática e a previsão da consequência jurídica de sua ocorrência, isto é, são determinações. Os segundos contêm a prescrição de um valor, são vetores axiológicos que possuem alto grau de abstração e, por serem vagos e indeterminados, não possuem aplicação direta, como as regras; são, portanto, mandatos de otimização, o que significa que devem ser realizados na maior medida possível, tendo em conta as possibilidades jurídicas e fáticas ${ }^{97}$.

$\mathrm{Na}$ aplicação das regras há de ser observada a conformidade entre os atos administrativos e as regras e, na aplicação do princípio, o que há é compatibilidade entre o ato e o princípio. "As regras, portanto, conferem segurança e concretude; os princípios, abertura e aproximação axiológica"98. Além disso, esclarece Ana Paula de Barcellos: "Os efeitos que o princípio deseja produzir são indeterminados a partir de um núcleo básico inicial ou, ainda que possam ser plenamente identificados, os meios para alcançá-los são múltiplos"99.

Assim, diferentemente das regras, os princípios não fornecem solução para situação concreta, embora conduza a busca por tal solução. Não encerram detalhes típicos da realidade concreta ou de uma situação determinada, expressando valores dominantes que se pretende ver aplicados. Enfim, os princípios se ligam mais à ideia de justiça, já que são instrumentos mais abertos, enquanto as regras priorizam a segurança ${ }^{100}$.

[BARROSO, Luís Roberto. Fundamentos teóricos e filosóficos do novo direito constitucional brasileiro (pós-modernidade, teoria crítica e pós-positivismo). In: BARROSO, Luís Roberto (Org.). A nova interpretação constitucional: ponderação, direitos fundamentais e relações privadas. 3. ed. rev. Rio de Janeiro: Renovar, 2008. p. 44].

${ }^{96}$ ALEXY, Robert. Teoría de los derechos fundamentales. Madrid: Centro de Estudios Políticos y Constitucionales, 2001. p. 87.

${ }^{97}$ Id. Ibid., p. 86-87 e 99.

${ }^{98}$ GABARDO, Emerson. Princípio constitucional da eficiência administrativa. São Paulo: Dialética, 2002. p. 79.

${ }^{99}$ BARCELLOS, Ana Paula de. A eficácia jurídica dos princípios constitucionais. 2. ed. ampl. rev. e atual. Rio de Janeiro: Renovar, 2008. p. 351.

${ }^{100}$ Id. Alguns parâmetros normativos para a ponderação constitucional. In: BARROSO, Luís Roberto (Org.). A nova interpretação constitucional: ponderação, direitos fundamentais e relações privadas. 3. ed. rev. Rio de Janeiro: Renovar, 2008. p. 79. 
Portanto, o princípio é um standard, um valor que direciona a interpretação e aplicação da norma. É o mandamento nuclear de um sistema que compõe o espírito da norma, e por meio dele é que se entende a intelecção das diferentes partes componentes do todo unitário do sistema jurídico positivo ${ }^{101}$. Os princípios são a base do ordenamento jurídico, possuem força cogente, fundamentando a atividade de todos aqueles que os utilizam.

\subsubsection{Considerações sobre princípios constitucionais}

Os princípios constitucionais possuem um papel fundamental no ordenamento jurídico devido à sua posição hierárquica no sistema das fontes, pois possuem supremacia e, portanto, importância estruturante dentro do sistema jurídico, constituindo o fundamento das regras jurídicas e vinculando todos os poderes públicos ${ }^{102}$.

Segundo Cármem Lúcia Antunes Rocha, os princípios constitucionais são a seiva que vivifica todas as normas que compõem a grande árvore do Direito, cultivada por uma sociedade estatal; são os valores superiores fundamentais adotados pela sociedade; neles residem a identidade da Constituição, a sua alma; abrangem os conteúdos primários diretores do sistema jurídico normativo fundamental do Estado e, dotados de originalidade e superioridade material sobre todos os conteúdos, "são eles que a mantêm em sua dimensão sistêmica, dando-lhe fecundidade e permitindo a sua atualização permanente"103.

Pode-se, então, afirmar que os princípios constitucionais têm como função assegurar unidade ao sistema jurídico fundamental, oferecendo objetividade e segurança ao modelo ético e político adotado pela sociedade estatal, e permitindo a integração e harmonia permanente e atualizada do sistema de Direito positivado ${ }^{104}$.

\footnotetext{
${ }^{101}$ MELLO, Celso Antônio Bandeira de. Curso de direito administrativo, cit., p. 949.

${ }^{102}$ CANOTILHO, José Joaquim Gomes. Direito constitucional. 6. ed. rev. Coimbra: Livr. Almedina, 1993. p. $166-167$ e 360.

${ }^{103}$ ROCHA, Cármen Lúcia Antunes. Princípios constitucionais da administração pública. Belo Horizonte: Del Rey, 1994. p. 23 e 25.

${ }^{104}$ Id. Ibid., p. 28.
} 


\subsubsection{Eficiência como princípio constitucional-administrativo}

O princípio da eficiência, como todo princípio, não possui caráter absoluto, mas sua introdução no ordenamento irradia vários efeitos. De imediato, ele pode ser impeditivo de conduta, que obsta o efeito de preceitos e atos que lhes sejam antagônicos, e, de forma mediata, o princípio se repassa para toda ordem jurídica por meio dos preceitos e dos atos concretos $^{105}$.

O princípio da eficiência é um princípio constitucional-administrativo ${ }^{106}$. Tais princípios têm a finalidade de corrigir a instabilidade do direito administrativo, caracterizado pela coleção de leis esparsas ${ }^{107}$, e equilibrar a dualidade entre os privilégios da Administração Pública e as garantias dos indivíduos ${ }^{108}$; são eles que dirigem a conduta da Administração Pública. Sua função é orientar o administrador na prática dos atos administrativos e garantir a boa administração na gestão pública, garantindo aos administrados o direito a práticas eficientes.

Deve-se adotar, no princípio da eficiência, interpretação e conteúdo que se compatibilize com os demais princípios constitucionais. Mesmo porque não haverá eficiência quando houver violação de algum desses princípios.

Apesar de não possuir conteúdo absolutamente preciso, o princípio possui um conteúdo mínimo, sobre o qual há um consenso. Embora esse consenso possa variar no tempo ou no espaço, pode ser de tal forma determinado que pode acabar por adquirir natureza de regra ${ }^{109}$. É esse núcleo que será estabelecido mais a frente.

\footnotetext{
${ }^{105}$ MOREIRA NETO, Diogo de Figueiredo. A lei de responsabilidade fiscal e seus princípios jurídicos. Revista de Direito Administrativo, Rio de Janeiro, n. 221, p. 71-93, jul./set. 2000.

${ }^{106}$ Para Ávila, a eficiência é um postulado, e, como postulado, diferentemente dos princípios, não impõe a promoção de um fim, mas sim estruturam a aplicação do dever de promover um fim, ou seja, não "prescrevem indiretamente comportamentos, mas modos de raciocínio e de argumentação relativamente a normas que indiretamente prescrevem comportamentos", isto é, estruturam a aplicação de normas que descrevem comportamentos. (ÁVILA, Humberto. Teoria dos princípios: da definição à aplicação dos princípios jurídicos. 7. ed. ampl. e atual. São Paulo: Malheiros Ed., 2007. p. 135-136).

${ }^{107}$ Conforme SUNDFELD, Carlos Ari. Fundamentos de direito público. 4. ed. 3 tir. São Paulo: Malheiros Ed., 2002. p. 147.

${ }^{108}$ Conforme DI PIETRO, Maria Sylvia Zanella. Discricionariedade administrativa na Constituição de 1988, cit., p. 170.

${ }^{109}$ BARCELLOS, Ana Paula de. Alguns parâmetros normativos para a ponderação constitucional, cit., p. 7475 .
} 


\subsubsection{Fundamento do princípio da eficiência}

Segundo Diogo de Figueiredo Moreira Neto, um dos fundamentos téoricos que orientou as reformas do Estado implementadas em quase todo o mundo ocidental "estava na recuperação e na ampliação da liberdade e da dignidade humanas, esmagadas por longos e sombrios decênios de submissão a ideologias e experiências despóticas, estatizantes e autoritárias" que lançaram bases para o neoliberalismo ${ }^{110}$.

O modelo atual de Estado, traçado pela Constituição Federal de 1988 (artigos $1^{\circ}, 3^{\circ}$ e 170), é que dirige a atuação do Estado, primordialmente para a garantia da dignidade da pessoa humana, fenômeno externo e anterior à ordem jurídica, mas nela incorporada e consagrada como reação às barbáries do nazismo e do fascismo no pós-guerra como princípio orientador da atuação estatal e dos organismos internacionais ${ }^{111}$.

A dignidade da pessoa humana é traduzida como

conjunto de situações materiais indispensáveis à existência humana digna; existência aí considerada não apenas como experiência física - a sobrevivência e a manutenção do corpo - mas também espiritual e intelectual, aspectos fundamentais em um Estado que se pretende, de um lado, democrático, demandando a participação dos indivíduos nas deliberações públicas, e, de outro, liberal, deixando a cargo de cada um seu próprio desenvolvimento. ${ }^{112}$

Trata-se de "vetor constitucional essencial para a ponderação de interesses, sendo o epicentro axiológico do ordenamento constitucional”. É a ideia-chave da dignidade da pessoa humana que confere unidade teleológica a todos os princípios e regras que compõem o ordenamento jurídico ${ }^{113}$, inclusive a eficiência.

No mesmo sentido, Jefferson Aparecido Dias ressalta a superioridade do princípio da dignidade da pessoa humana em relação aos demais, na medida em que ele "impõe o

\footnotetext{
${ }^{110}$ MOREIRA NETO, Diogo de Figueiredo. Coordenação gerencial na Administração Pública (administração pública e autonomia gerencial, contratos de gestão, organizações sociais. A gestão associada de serviços públicos: consórcios e convênios de cooperação). Revista da Procuradoria Geral do Estado da Bahia, Salvador, v. 24, p. 29-53, jan./dez. 1998.

${ }^{111}$ BARCELLOS, Ana Paula de. A eficácia jurídica dos princípios constitucionais, cit., p. 126 e 219.

${ }^{112}$ Id. Ibid., p. 230.

${ }^{113}$ BATISTA JÚNIOR, Onofre Alves. op. cit., p. 108.
} 
reconhecimento do homem como fim e impede a sua adoção como meio para a obtenção de qualquer outro resultado, inclusive a riqueza" ${ }^{\text {114 }}$.

Deste modo, a eficiência consistiria em atingir a finalidade plena do ordenamento jurídico, que é a satisfação das necessidades coletivas e o atendimento dos direitos individuais dos administrados, destinados à preservação da dignidade da pessoa humana; seria um mandamento de otimização dos meios e recursos para o alcance das necessidades necessárias para atingir esse fim. Pode significar, ainda, "medir os custos que a satisfação das necessidades públicas importam em relação ao grau de utilidade alcançado", lembrando que, por mais que o Estado seja pluralista, há um núcleo de condições materiais que compõe a noção de dignidade da pessoa humana de maneira tão profunda que sem elas tal pilar não se realiza ${ }^{116}$.

Assim, o princípio da eficiência se pauta pela necessidade de se garantir os meios mínimos necessários para o desenvolvimento da personalidade dos administrados e do progresso da coletividade, sempre com o fim de não se deixar desamparadas as necessidades imprescindíveis para a manutenção da dignidade da pessoa humana.

\subsubsection{Efeitos da introdução da eficiência como princípio na Constituição Federal}

A reforma foi criticada por não atacar os reais problemas do aparelho administrativo e por estar focada apenas em aspectos ideológicos. Resumindo tais críticas, Emerson Gabardo comenta que pouco adianta a reforma se "não se atacam os elementos que pervertem a Administração (seja no regime burocrático, no neoliberal, ou qualquer outro), como corrupção, nepotismo, fisiologia, má utilização de recursos públicos, corporativismo, falta de investimento físico e humano, entre outros"117.

O fato é que mesmo após tanto tempo do início da reforma, pouco se viu de efetiva mudança no desenvolvimento da atividade estatal, principalmente na atividade típica de Estado, e na satisfação dos funcionários ou dos próprios cidadãos, o que realmente conduz ao questionamento sobre a sua utilidade ou, até mesmo, necessidade.

\footnotetext{
${ }^{114}$ DIAS, Jefferson Aparecido. op. cit., p. 106.

${ }^{115}$ SILVA, José Afonso da. op. cit., p. 671.

${ }^{116}$ BARCELLOS, Ana Paula de. A eficácia jurídica dos princípios constitucionais, cit., p. 226-227 e 277288.

${ }^{117}$ GABARDO, Emerson. op. cit., p. 66-67.
} 
Alguns juristas observam que teria havido apenas um atraso na constitucionalização expressa do princípio da eficiência, uma vez que ele já constava do sistema implicitamente ${ }^{118}$. Desta forma, tal introdução foi considerada redundante para alguns autores.

Uadi Lammêgo Bulos, entretanto, recomenda interpretar a alteração implementada por referida emenda com isenção de ânimo e espírito de abertura, sem o vício da antipatia $^{119}$, recomendação esta que reiteramos.

De fato, a eficiência não é inovação da Emenda Constitucional no 19/98, pois já era prevista de forma dispersa em leis, no texto constitucional e na jurisprudência ${ }^{120}$.

A introdução do princípio da eficiência no texto constitucional, por si só, não é suficiente para transformar a forma de atuação do Estado. No entanto, por poder ser imediatamente exigível e concretizável, vinculando imediatamente o agente público, marca a introdução de uma concepção capaz de promover o avanço cultural dos administradores e de colaborar com atitudes inovadoras antes escondidas nas teias do rigor e do costume estrutural e procedimental. Agora, há respaldo e desculpa constitucional para aqueles que se animam a impor mudanças em determinadas condutas arraigadas na atuação funcional.

Assim, "a positivação de um princípio é sempre benéfica e desejável, sobretudo por produzir um efeito irradiante, de abertura sistêmica, de elevadíssimo cunho didáticopedagógico, ao dar relevo e nitidez aos valores e fins que porta"121.

\footnotetext{
${ }^{118}$ No mesmo sentido: STJ, ROMS 5590/DF, DJ 10.6.1996, p. 20395; STF, RE 160.381/SP, Ministro Marco Aurélio, DJ 12.8.1994, p. 20052.

${ }^{119}$ BULOS, Uadi Lammêgo. Reforma administrativa (primeiras impressões). Revista de Direito Administrativo, Rio de Janeiro, n. 214, p. 69-98, out./dez. 1998.

${ }^{120}$ Artigos 74 , II e $144, \S 7^{\circ}$ (expressamente), 71 , IV e 175 , IV, parágrafo único (implicitamente) da Constituição Federal; artigo 122 da Constituição Estadual; artigo 123, parágrafo único, da Lei Orgânica do Município de São Paulo; artigos $6^{\circ}$, $\S 1^{\circ}$ e $7^{\circ}$ da Lei ${ }^{\circ}$ 8.987/1995; artigo $3^{\circ}$ da Lei $n^{\circ} 8.666 / 93$; artigo $2^{\circ}$ da Lei $\mathrm{n}^{\circ}$ 8.784/99; e artigos $6^{\circ}$, X e 22 do Código de Consumidor, artigos 16, III e 100 do Decreto-Lei $\mathrm{n}^{\circ}$ 200/67, por exemplo.

No STJ, no Resp. 687.947-MS, em voto vista, o Ministro João Otávio de Noronha aplicou o princípio da eficiência a situação ocorrida a situação anterior à sua introdução como princípio constitucional. O mesmo ocorreu no RMS 5.590-DF, Ministro Luiz Vicente Cernicchiaro, DJ 10.6.1996; RMS 7.730-RS, Ministro José Delgado, DJ 27.10.97; RESP 169876/SP; Resp. 98/0023955-3, Ministro José Delgado, DJ 21/09/1998. No STF: RMS-2201/DF, Ministro Abner de Vasconcelos, DJ 22.7.54, Tribunal Pleno; Rp 1207/DF, Ministro Aldir Passarinho, DJ 18/4/1986, p. 5988; RE 27.246/DF, Ministro Afranio Costa, DJ 9/9/1955, p. 540; RE 25.976, Ministro Afranio Costa, DJ 7/7/1955, p. 8143; MS 1.465/Guanabara, Ministro Afranio Costa, DJ 15/5/1952, p. 4667.

No TFR: AC 72.781/PA, Ministro Adhemar Raymundo, DJ 16/6/1983, p. 71; AC 34.478/SP, Ministro Aldir Passarinho, DJ 26/3/1981, p. 101; AMS 103.801, Ministro Jesus Costa Lima, DJ 26/9/1985, p. 48.

${ }^{121}$ MOREIRA NETO, Diogo de Figueiredo. A lei de responsabilidade fiscal e seus princípios jurídicos, cit., p. 71-93.
} 


\subsubsection{Conteúdo da eficiência}

Não há, na doutrina ou no ordenamento pátrio, conceito uniforme sobre a eficiência. A primeira observação que se faz, entretanto, é que a eficiência não é dotada de conteúdo específico, pois pode variar de acordo com as necessidades mutáveis da realidade e de acordo com o foco de análise e a perspectiva científica empregada ${ }^{122}$.

Trata-se de um conceito jurídico indeterminado cujo conteúdo será delimitado no momento de sua aplicação ao caso concreto.

No entanto, como todo princípio e/ou conceito jurídico indeterminado, certamente, há um núcleo que deve ser definido para se extrair o mínimo de entendimento sobre o instituto.

Nesse sentido, deve-se entender que a eficiência decorre da existência da função estatal que, por sua vez, implica, por si mesma, na necessidade de desempenhá-la da melhor maneira possível ${ }^{123}$. Para alguns autores, esse desempenho seria a materialização dos objetivos das normas com o menor prejuízo possível. Vejamos.

Alexandre Santos Aragão afirma:

A eficiência não pode ser entendida apenas como maximização do lucro, mas sim como um melhor exercício das missões de interesse coletivo que incumbe ao Estado, que deve obter a maior realização prática possível das finalidades do ordenamento jurídico, com os menores ônus possíveis, tanto para o próprio Estado, especialmente de índole financeira, como para as liberdades dos cidadãos. ${ }^{124}$

Para o autor: "O direito deixa de ser aquela ciência preocupada apenas com a realização lógica dos seus preceitos; desce do seu pedestal para aferir se esta realização lógica está sendo apta a realizar os seus desígnios na realidade na vida em sociedade"125.

Para Antonio Silvio Magalhães Junior,

o princípio da eficiência corresponde ao dever do administrador de atuar com o intuito de alcançar resultado previamente estabelecido, mas de forma a maximizá-lo o quanto possível, quantitativamente e qualitativamente, mas de modo a também despender o mínimo possível,

\footnotetext{
${ }^{122}$ Conforme GABARDO, Emerson. op. cit., p. 23.

${ }^{123}$ FALZONE, Guido. Il dovere di buona amministrazione: parte I. Milano: Giuffrèe, 1953. p. 99.

${ }^{124}$ ARAGÃO, Alexandre Santos. O princípio da eficiência. Revista de Direito Administrativo, Rio de Janeiro, n. 237, p. 1-6, jul./set. 2004.

${ }^{125}$ Id. Ibid., p. 1-6.
} 
desde que respeitados os procedimentos e regras previstos em lei, de observância obrigatória pelo Estado, bem como atendido o interesse público $^{126}$.

Explica Onofre Alves Batista Júnior que o ordenamento jurídico confere à Administração Pública uma primeira função que é a de atender ao bem comum, sendo que o princípio da eficiência qualifica esta função com o dever de bom cumprimento, de melhor satisfação do bem comum, não se contentando com o mero cumprimento ${ }^{127}$.

Para Adílson Abreu Dallari:

É certo que as necessidades a satisfazer são sempre maiores que as disponibilidades, até porque o atendimento daquilo que é mais premente desperta ou aviva novas aspirações. Não é possível fazer tudo, mas aquilo que for feito deve ser bem feito. Quando não for possível fazer o ótimo, que se faça o bom, mas quando a Administração assume um encargo, ela assume também a obrigação de ser eficiente. ${ }^{128}$

Nesse contexto, o princípio da eficiência agiria de forma a proporcionar "rentabilidade social"129, que, segundo Alexandre de Moraes, é a "melhor utilização possível dos recursos públicos, de maneira a evitarem-se desperdícios"130.

Isso não quer dizer, entretanto, que o conteúdo do princípio da eficiência seja eminentemente econômico. A concepção econômica do princípio da eficiência, como maximização da riqueza, estando nela inserido o aspecto da economicidade, apesar de ser defendida, pode ser reconhecida apenas como um de seus aspectos. "O problema não é apenas econômico, como se fosse pouco, mas de legitimação do próprio Estado, cujos parâmetros de atuação deveriam resultar voltados à satisfação da cidadania, na esfera pública", ensina Fábio Medina Osório, ao tratar da improbidade administrativa, na qual ele inclui a grave ineficiência funcional ${ }^{131}$.

O autor defende que a boa gestão, conceito, para ele, genérico, que abrange a

${ }^{126}$ MAGALHÃES JÚNIOR, Antonio Silvio. O controle da administração pública pelo Tribunal de Contas. 2005. Dissertação (Mestrado) - Faculdade de Direito, Universidade de São Paulo, São Paulo, 2005. p. 104.

${ }^{127}$ BATISTA JÚNIOR, Onofre Alves. op. cit., p. 88.

${ }^{128}$ DALLARI, Adilson Abreu. Administração pública no Estado de direito. Revista Trimestral de Direito Público, São Paulo, v. 94, n. 5, p. 33-41, 1994.

${ }^{129}$ MORAES, Alexandre de. Princípio da eficiência e o controle jurisdicional dos atos administrativos discricionários. Revista de Direito Administrativo, Rio de Janeiro, n. 243, p. 13-28, set./dez. 2006.

${ }^{130}$ Id. Constitucionalização do direito administrativo e princípio da eficiência. In: FIGUEIREDO, Carlos Maurício; NÓBREGA, Marcos (Orgs.). Administração pública: direitos administrativo, financeiro e gestão pública: prática, inovações e polêmicas. São Paulo: Ed. Revista dos Tribunais, 2002. p. 37.

${ }^{131}$ OSÓRIO, Fábio Medina. Teoria da improbidade administrativa: má gestão pública, corrupção e ineficiência, cit., p. 310 . 
eficiência, "pressupõe respeito pelos direitos fundamentais da pessoa humana e satisfação das demandas da cidadania, cumprindo as exigências do liame de confiança que une e deve unir governantes e governados, administradores e administrados"132.

Assim, quando se fala de utilização dos meios menos onerosos para o atingimento das finalidades previstas, pode-se querer se referir ao custo suportado pela sociedade e aos particulares decorrentes de quaisquer imposições estatais, e não apenas o custo econômico, como foi bem lembrado por Mateus Piva Adami ${ }^{133}$. Além disso, lembra o autor que o critério de seleção da opção é o resultado da ponderação, e não a menor onerosidade em si, porque uma opção mais onerosa, por acarretar maior benefícios, pode se revelar a ideal em determinado caso concreto ${ }^{134}$.

Por tudo isso, pode-se concluir que o princípio da eficiência consiste na adoção de atos que alcancem satisfatoriamente o objetivo visado pela lei, sendo este sempre atrelado à satisfação dos interesses públicos, com o menor prejuízo possível dos diversos aspectos indisponíveis da relação social, entre eles, o patrimônio público e os direitos fundamentais, havendo necessidade de constante aperfeiçoamento para que seja garantido o desenvolvimento de técnicas que proporcionem o amadurecimento da coletividade suficiente e necessário para o alcance disto que se busca ${ }^{135}$.

\subsubsection{Eficiência como meio e como fim}

Os autores se dividem - uns considerando o resultado mais importante e outros, o meio.

A adoção de um ou outro entendimento de forma isolada pode acarretar a equivocada conclusão de que a eficiência é apenas um critério de controle, de fiscalização, e não um valor em si.

É certo que o resultado mal atingido, em regra, decorre de uma ação má realizada. Existe uma relação lógica entre o atendimento do fim e as medidas adotadas para alcançá-

\footnotetext{
${ }^{132}$ OSÓRIO, Fábio Medina. op. cit., p. 45.

${ }^{133}$ ADAMI, Mateus Piva. A discricionariedade administrativa em face do princípio da eficiência. 2007. Dissertação (Mestrado) - Faculdade de Direito, Universidade de São Paulo, São Paulo, 2007. p. 26-27.

${ }^{134}$ Id. Ibid., p. 142.

${ }^{135}$ VALLE, Vanice Lírio do. Direito fundamental à boa administração, políticas públicas eficientes e prevenção do desgoverno. Interesse Público, Porto Alegre, v. 10, n. 48, p. 87-109, mar./ago. 2008.
} 
lo; não se alcança o fim se as medidas não forem adequadas e o correto desenvolvimento do meio, geralmente, garante o sucesso no resultado ${ }^{136}$.

O meio é importante na concretização do princípio, sobretudo nas obrigações de meio, nas quais, ainda que aplicadas as melhores técnicas, não há garantia de resultado eficiente ou positivo ${ }^{137}$.

Observa Mateus Piva Adami, entretanto, que o foco no meio pode fazer com que os fins não sejam alcançados no final; pode onerar os custos também. Assim, deve haver "eficiência como meio" e "eficiência como meta". O primeiro seria o processo de comparação entre as alternativas disponíveis para o alcance do fim e o segundo é o cumprimento ou não do objetivo $^{138}$.

No mesmo sentido, Ubirajara Custodio Filho, para quem a "eficiência é qualidade que se avalia tanto em razão dos resultados, quanto em face do modo de aproveitamento dos recursos" $" 139$.

De igual modo, o resultado, em caráter isolado, não é suficiente para justificar os meios empregados, sob pena de restar abalado o Estado de Direito. A adoção de procedimentos publicísticos não está unicamente delegada à apreciação aleatória do administrador, mas é condicionada por parâmetros traçados pelo ordenamento jurídico. $\mathrm{O}$ resultado em si mesmo não é bastante para concluir-se pela capacidade do administrador. Daí o conceito de efetividade, como a consagração de meios e fins mais apropriados para nortear a conduta da Administração Pública. ${ }^{140}$

Assim é que se verifica que a eficiência a que se refere a Constituição Federal há de ter um conteúdo mais amplo do que apenas de meio e de fim $^{141}$, devendo englobar os dois aspectos.

\footnotetext{
${ }^{136}$ MARTINS, Alzemeri; SOUZA, Marisa Idalência de. O princípio constitucional da eficiência, aplicação à função do Procurador do Estado no exercício da consultoria jurídica. Revista da Procuradoria Geral do Estado da Bahia, Slavador, v. 25, p. 59-98, jan./dez. 1999.

${ }^{137}$ Segundo o STJ, aquele que desenvolve obrigação de meio de forma diligente, aplicada, possível, estará cumprindo a sua obrigação funcional e profissional, ainda que o resultado final seja adverso. (STJ, MS ${ }^{\circ}$ 10.220/DF, Ministro Arnaldo Esteves Lima, DJU 13.8.2007).

${ }^{138}$ ADAMI, Mateus Piva. op. cit., p. 8 e 146.

${ }^{139}$ CUSTODIO FILHO, Ubirajara. A Emenda Constitucional $19 / 98$ e o princípio da eficiência na Administração Pública. Cadernos de Direito Constitucional e Ciência Política, São Paulo, v. 7, n. 27, p. 209-217, 1999.

${ }^{140}$ RAMOS, Dora Maria de Oliveira. op. cit., p. 139.

${ }^{141}$ SANTIN, Valter Foleto. Controle judicial da eficiência do serviço de segurança pública na prevenção e repressão ao crime. 2003. Tese (Doutorado) - Faculdade de Direito, Universidade de São Paulo, São Paulo, 2003. p. 121.
} 
Portanto, pode-se dizer, utilizando-se dos ensinamentos de Paulo Modesto, que a atuação eficiente se desenvolve sob duas dimensões, que são indissociáveis: a da racionalidade e otimização do uso dos meios e a da satisfatoriedade dos resultados da atividade $^{142}$. É nisso consiste o dever de boa administração, ou seja, na escolha adequada dos meios e no alcance, com sucesso, do resultado ${ }^{143}$.

\subsubsection{Parâmetros normativos do princípio da eficiência}

Vimos que o princípio da eficiência foi ancorado em disciplina não jurídica e, por isso, não possui conteúdo jurídico formulado por norma. No entanto, como toda norma jurídica, a eficiência possui um conteúdo mínimo de compreensão, sem o qual não possui qualquer valor.

Isso, entretanto, não dispensa uma necessária objetivação para a sua adequada aplicação, sugerindo, Diogo de Figueiredo Moreira Neto, o emprego de indicadores de desempenho. Esses nada mais seriam do que as metas de desempenho já previstas constitucionalmente (artigo 37, $\S 8^{\circ}$, II), "o que pressupõe que elas venham a ser estabelecidas de modo que a quantidade e a qualidade dos índices escolhidos indiquem, adequadamente, a variação no cumprimento das metas de eficiência estabelecidas"144.

Afirma Egon Bockmann Moreira, referindo-se ao princípio em questão: "Exige configuração precisa e minuciosa, mediante pautas de comportamento predefinidas - que estabeleçam normativamente o alcance de específicos resultados e a utilização dos recursos certos. Caso contrário inexistirá a 'relação' definidora da eficiência"145.

O desenvolvimento de técnicas jurídicas de parametrização da eficiência pelo direito administrativo ou um vocábulo comum para se dizer se algo é ou não eficiente, como, por exemplo, uma previsão de padrão para sua aferição, tal como propõe Avalcir Correa dos Santos ${ }^{146}$, também teria grande utilidade na concretização de referido princípio.

\footnotetext{
${ }^{142}$ MODESTO, Paulo. Notas para um debate sobre o princípio constitucional da eficiência, cit.

${ }^{143}$ MELLO, Celso Antonio Bandeira de. O controle judicial dos atos administrativos. Revista de Direito Administrativo, Rio de Janeiro, n. 152, p. 1-15, abr./jun. 1983.

${ }^{144}$ MOREIRA NETO, Diogo de Figueiredo. Mutações do direito administrativo. 3. ed. rev. e ampl. Rio de Janeiro: Renovar, 2007. p. 396.

${ }^{145}$ MOREIRA, Egon Bockmann. Processo administrativo: princípios constitucionais e a Lei 9.784/1999. 3. ed. atual. e aumen. São Paulo: Malheiros Ed., 2007. p. 171.

${ }^{146}$ SANTOS, Alvacir Correa dos. Princípio da eficiência da administração pública, cit., p. 215 e 256.
} 
Vê-se, portanto, a importância de o legislador estabelecer normas para que o princípio da eficiência tenha sua aplicação parametrizada. Lembre-se que a moralidade também possui conceito cambiante, tendo havido certa dificuldade em se situá-la inicialmente, pois, assim como a eficiência, é um conceito jurídico indeterminado. Isso não impediu, entretanto, sua determinação por meio da lei 9.784/99, que fixou as condutas ofensivas à moralidade administrativa. Foram padrões inseridos no ordenamento jurídico que viabilizaram a formação da ideia sobre a moralidade contida no texto constitucional.

Pois bem, no que se refere ao princípio da eficiência, tem-se que o artigo 27 da Emenda Constitucional n ${ }^{\circ} 19 / 98$ estabeleceu o prazo de 120 dias para o Congresso Nacional elaborar a lei de defesa do usuário de serviços públicos, o que ainda não aconteceu.

O projeto de Lei-Complementar n ${ }^{\circ}$ 248-D, de 1998, que disciplina a perda de cargo por insuficiência de desempenho do servidor público estável, propõe alguns parâmetros para uma atuação eficiente, como o cumprimento das normas de procedimento e de conduta no desempenho das atribuições do cargo, a produtividade no trabalho com base em padrões previamente estabelecidos de qualidade e de economicidade, assiduidade, pontualidade e disciplina, etc.

A Lei paulista $n^{\circ} 10.294$, de 20 de abril de 1999, que dispõe sobre a proteção e defesa do usuário do serviço público do Estado de São Paulo, relaciona alguns exemplos de qualidade do serviço, como: I - urbanidade e respeito no atendimento aos usuários do serviço; II - atendimento por ordem de chegada, assegurada prioridade a idosos, grávidas, doentes e deficientes físicos; III - igualdade de tratamento, vedado qualquer tipo de discriminação; IV - racionalização na prestação de serviços; V - adequação entre meios e fins, vedada a imposição de exigências, obrigações, restrições a sanções não previstas em lei; VI - cumprimento de prazos e normas procedimentais; VII - fixação e observância de horário e normas compatíveis com o bom atendimento do usuário; VIII - adoção de medidas de proteção à saúde ou segurança dos usuários; IX - autenticação de documentos pelo próprio agente público, à vista dos originais apresentados pelo usuário, vedada a exigência de reconhecimento de firma, salvo em caso de dúvida de autenticidade; $\mathrm{X}$ manutenção de instalações limpas, sinalizadas, acessíveis e adequadas ao serviço ou atendimento; XI - observância dos Códigos de Ética aplicáveis às várias categorias de agentes públicos. 
Apesar de tais parâmetros notadamente não serem suficientes para abranger a amplitude do princípio, são ótimos exemplos que tornam objetivo o instituto da eficiência. Enquanto não se experimenta progresso nesse sentido, quer dizer, enquanto os parâmetros seguem insuficientemente normatizados, cumpre à Administração Pública fazer, mesmo assim, o seu melhor, ainda que a percepção do conceito de eficiência continue sendo, como até agora, puramente intuitiva e aproximativa, o qual relativiza muito seriamente sua utilidade como parâmetros de valoração jurídica ${ }^{147}$.

${ }^{147}$ Conforme SANTAMARIA PASTOR, Juan Alfonso. Estado social de derecho y control jurídico de eficacia de la administración pública. Revista Brasileira de Direito Público - RBDP, Belo Horizonte, ano 5, n. 19, p. 165-179, out./dez. 2007. 


\section{CAPÍTULO 2. DEVER DE EFICIÊNCIA}

\subsection{Sentido dúplice do dever de eficiência}

O dever de eficiência do funcionário público somente poderá ser cobrado a partir do momento em que o mesmo tenha as condições necessárias e suficientes que permitam o desenvolvimento de um comportamento eficiente.

Desta forma, o Estado, como empregador, tem o dever de fornecer o suporte necessário para o desenvolvimento de uma atividade eficiente e fomentar um sentido construtivo e de aperfeiçoamento contínuo das atividades desenvolvidas. É necessário desenvolver no servidor público o orgulho e a consciência de que contribuem para a realização de um trabalho tão importante que é a satisfação social.

A seguir, delinearemos os instrumentos necessários para o alcance de tal intento. $\mathrm{Na}$ verdade, a maioria deles se apresenta como um verdadeiro consenso, o que nos leva a concluir que não haveria indeterminação a respeito do funcionamento eficiente da Administração Pública e que, talvez, um sistema adequado não seja implantado por outras razões que não propriamente a incerteza ou a indefinição de como deveria funcionar.

\subsection{Instrumentos para o cumprimento do dever de eficiência}

\subsubsection{Organizacional}

A eficiência deve estar presente na organização dos componentes da estrutura administrativa que, em geral, estão pré-definidos em lei, competindo ao legislador a incumbência de melhor sintonizá-los de acordo com as necessidades da realidade.

Organization is the arrangement of personnel for facilitating the accomplishment to some agreed purpose through the allocation of functions and responsibilities. It is the relating of efforts and capacities of individuals and groups engaged upon a common task in such a way as to secure the desired objective with the least friction and the most satisfaction to those for whom the task is done and those engaged in the enterprise. $^{148}$

\footnotetext{
148“"Organização é o arranjo de pessoas que visa facilitar o alcance de alguns objetivos acordados pelo grupo
} através da alocação de funções e responsabilidades. Relaciona-se com os esforços e as capacidades dos 
Assim, a organização é a parte estática que agrupa as funções de forma a melhor se adequarem ao alcance da finalidade do grupo.

Conforme Alvacir Correa dos Santos: "A eficácia de uma organização é determinada pela sua capacidade de concentrar-se em uma tarefa" ${ }^{149}$ e deve ser adequada aos fins propostos.

A adoção de determinada organização depende de elaboração de prévios estudos e trabalhos técnicos, que visam adequá-la às peculiaridades e finalidades perseguidas. Não cabe, portanto, no presente trabalho, apresentar ou definir qual a organização administrativa adequada para o desenvolvimento das atividades públicas com presteza, já que, para tanto, necessário seria invadir campo de atuação que foge ao âmbito da ciência jurídica.

No atual sistema normativo, a organização é escolha feita pelo legislador dentro das alternativas oferecidas pela Ciência da Administração. É ao Poder Legislativo que cumpre disciplinar a organização administrativa de forma eficiente, buscando otimizar o alcance dos desígnios constitucionais ${ }^{150}$. Isso porque, no ordenamento jurídico pátrio, a organização da Administração Pública somente pode ser objeto de lei ou de reforma constitucional. O artigo 84, VI, "a" da Constituição Federal não permite ao Presidente da República dispor, mediante decreto, sobre a organização da administração que implicar em criação ou extinção de órgãos públicos.

Ocorre que a necessidade de o projeto de criação ou modificação da estrutura organizacional ter que passar pelo Poder Legislativo acarreta algumas desvantagens, pois tal Poder não possui qualquer habilidade técnica administrativa. Além disso, durante o processo de elaboração de leis, pode haver inúmeras alterações capazes de desconfigurar e desvirtuar um projeto que, inicialmente, poderia ter se mostrado apto a prestigiar a eficiência.

Além disso, este demorado sistema de elaboração normativa acaba por acarretar a estagnação de uma organização, cuja mutação haveria de acompanhar o desenvolvimento das técnicas administrativas e da realidade e, ainda, unir, sob uma mesma forma de organização, diferentes segmentos da Administração Pública, respeitando a peculiaridade

indivíduos e dos grupos engajados em uma tarefa comum, de forma a assegurar o objetivo desejado com o menor atrito e com a maior satisfação para aqueles aos quais a tarefa é feita e aqueles engajados no empreendimento." (tradução livre) (GAUS, John M. A theory of organization in public administration. GAUS, John M.; WHITE, Leonard D. DIMOCK, Marshall E. The frontiers or Public Administration. Illinois, Chicago: The University of Chicago Press, 1936. p. 66-67).

${ }^{149}$ SANTOS, Alvacir Correa dos. op. cit., p. 24.

${ }^{150}$ Id. Ibid., p. 679. 
de cada função a ser desenvolvida, sem dispersar e desperdiçar, desta forma, as energias de trabalho e tempo.

Assim, logo se conclui que essa forma de se estruturar e organizar a Administração Pública não se mostra compatível com a dinâmica necessária para uma boa administração estatal.

\subsubsection{Operacional}

Trata-se da forma de coordenar os elementos da organização em sua atividade diária, com o fito de alcançar os objetivos visados pelo grupo ${ }^{151}$.

Para Hely Lopes Meirelles, esse instrumento consiste nas técnicas de administração que, quando bem utilizadas, contribuem para o cumprimento do dever de eficiência na prestação da atividade administrativa. Segue a diferenciação entre a organização, acima tratada, e a operação, aqui delineada.

Nesse campo estrutural e funcional do Estado atua o moderno Direito Administrativo organizatório, auxiliado pelas contemporâneas técnicas de administração, aquele estabelecendo o ordenamento jurídico dos órgãos, das funções e dos agentes que irão desempenhá-las, e estas informando sobre o modo mais eficiente e econômico de realizá-las em benefício da coletividade. O Direito Administrativo impõe as regras jurídicas de organização e funcionamento do complexo estatal; as técnicas de administração indicam os instrumentos e a conduta mais adequada ao pleno desempenho das atribuições da Administração. Assim, embora sendo disciplinas diferentes, ambas devem coexistir em toda organização estatal, autárquica, fundacional e paraestatal, a fim de bem ordenar os órgãos, distribuir, fixar as competências e capacitar os agentes para a satisfatória prestação dos serviços públicos ou de interesse coletivo, objetivo final e supremo do Estado em todos os setores do Governo e da Administração. ${ }^{152}$

Pois bem, tal instrumento, aqui denominado operacional, é a relação de coordenação que se estabelece, dentro da estrutura da Administração Pública, entre aqueles que desenvolvem a atividade administrativa, os agentes públicos e os entes administrativos, visando alcançar os objetivos do Estado.

Com o fito de se concretizar a almejada eficiência na administração pública,

\footnotetext{
${ }^{151}$ GAUS, John M. op. cit., p. 69.

${ }^{152}$ MEIRELLES, Hely Lopes. Direito administrativo brasileiro, cit., p. 63.
} 
surgiram novos institutos no direito administrativo, que quebraram a forma tradicional de se operacionalizar as atividades do Estado.

A reforma constitucional tratada neste trabalho introduziu na Constituição Federal, por meio do artigo $37, \S \S 8^{\circ}$ e $9^{\circ}$, a possibilidade de concessão indireta de gestão gerencial, orçamentária e financeira da administração direta e indireta, das empresas públicas e das sociedades de economia mista, e suas subsidiárias, que recebem recursos da União, dos Estados, do Distrito Federal ou dos Municípios para pagamento de despesas de pessoal ou de custeio em geral.

Destaca-se o contrato de gestão, que é a principal ferramenta utilizada para a clara definição dos indicadores de desempenho para as instituições centralizadas na administração pública gerencial ${ }^{153}$. Alexandre de Moraes assim descreve o contrato de gestão:

A característica básica do contrato de gestão é a atuação consensual entre o Estado e seus cooperados ou colaboradores na prossecução dos interesses públicos, em respeito ao recentemente consagrado princípio da eficiência, tendo, portanto, o objetivo primordial de estabelecimento de determinadas metas a serem alcançadas pelas entidades, que devem obter, em contrapartida, algum benefício outorgado pelo Poder Público. O contrato de gestão deve ser estabelecido por tempo determinado, ficando a entidade sujeita a controle de resultado para verificação do cumprimento das metas estabelecidas. ${ }^{154}$

A Constituição Federal, no artigo 241, também prevê “consórcios públicos e os convênios de cooperação entre entes federados, autorizando a gestão associada de serviços públicos, bem como a transferência total ou parcial de encargos, serviços, pessoal e bens essenciais à continuidade dos serviços transferidos".

Para Diogo de Figueiredo Moreira Neto, essa administração pública coordenativa, multilateral e radial deve preponderar sobre a administração pública subordinativa, unilateral, hierarquizada e linear, apontando diversos aspectos que a qualificam, dentre os quais destacamos o potencial criativo da sociedade e dos próprios entes estatais, a simplificação da máquina gestora do Estado, o atendimento às demandas reprimidas após o fracasso dos antigos modelos e a racionalização da distribuição de competência dentro do

\footnotetext{
${ }^{153}$ Conforme PEREIRA, Luiz Carlos Bresser. Reforma do Estado para a cidadania: a reforma gerencial brasileira na perspectiva internacional, a reforma gerencial brasileira na perspectiva internacional. São Paulo: Ed. 34; Brasília: ENAP, 1998. p. 147.

${ }^{154}$ MORAES, Alexandre de. Reforma administrativa: Emenda Constitucional no 19/98. 4. ed. São Paulo: Atlas, 2001. p. 62-63.
} 
Estado $^{155}$.

A operação/coordenação é justamente a utilização maximizada da organização (aspecto técnico, estático) e dos recursos humanos (aspecto humano, dinâmico) para o alcance do fim do Estado; significa manejar tais elementos para a persecução de determinados fins ou satisfação de necessidades específicas ${ }^{156}$.

“O administrador dá direção e rumo às suas organizações, proporciona liderança às pessoas e decide como os recursos organizacionais devem ser dispostos e utilizados para atingir os objetivos da organização" $" 157$.

O desempenho indevido da atividade de coordenação, aqui chamado operacional, pode colocar em risco a eficiência de qualquer sistema tecnicamente perfeito. Aliás, é justamente nesta atividade que podem ser encontradas, e delas podem ser emanadas, as mais importantes mazelas e patologias que acometem as instituições públicas e a gestão do Estado.

Por isso, essa atividade deveria ser realizada por profissional técnico, tal como ocorre nas empresas privadas, que não sofresse ingerências políticas e possuísse incorrompível comportamento moral, que pudesse extrair de todos os aspectos da organização, da estrutura e de seus agentes o máximo proveito para o alcance da finalidade primordial do Estado.

Nesse sentido é que práticas comuns ao serviço público, como, por exemplo, o nepotismo $^{158}$, eivam a atuação da Administração Pública na consecução de seus fins, na medida em que é desenvolvida por pessoas despreparadas para a realização da atividade. É preciso estudo específico e direcionado para tal atuação.

Segundo Fabio Medina Osório, há uma escassez de profissionais técnicos nos altos escalões, ou seja, nos escalões que ditam toda a política a ser desenvolvida no Estado, que produzem decisões de extrema importância para o Estado. Tais pessoas não são indicadas para o exercício da função por força da sua qualificação técnica, mas, muitas vezes, por

\footnotetext{
${ }^{155}$ MOREIRA NETO, Diogo de Figueiredo. Coordenação gerencial na administração pública. Revista de Direito Administrativo, Rio de Janeiro, n. 214, p. 35-53, out./dez. 1998.

${ }^{156}$ MOURA, Paulo Veiga e. Função pública: regime jurídico, direitos e deveres dos funcionários e agentes, cit., p. 11.

${ }^{157}$ CHIAVENATO, Idalberto. Administração dos novos tempos. 2. ed. 7. tir. Rio de Janeiro: Campus, 1999.

p. 5.
${ }^{15}$ Sobre nepotismo e eficiência, veja-se: STF, RE 579.951, Ministro Ricardo Lewandowisk, DJ 24/10/2008, p. 1876; ADC-MC 12/DF, Ministro Carlos Britto, DJ 1/9/2006, p. 15.
} 
conta de interesses políticos, o que acarreta irremediáveis danos para toda a sociedade ${ }^{159}$; o mesmo ocorre com as funções necessárias para o desempenho da atividade tratada neste tópico.

Para que houvesse equacionamento da questão, imprescindível fosse observado um esquema de mérito pelo qual "os incapacitados moral e intelectualmente nunca cheguem a chefiar nenhuma repartição, por menor que seja" e "confira aos capacitados possibilidades de ascensão funcional, evitando assim que os incapacitados se apeguem a 'pistolões' para serem elevados a ocupar postos que, pelo mérito, não lhes competem"160.

Para conferir harmonia, uniformidade, continuidade de desenvolvimento de tal atividade, há de haver pessoal intelectualmente, tecnicamente e comportamentalmente vocacionado para o exercício de tal atividade, ainda que esteja dentro da própria Administração Pública.

\subsubsection{Direcional}

A administração pública não se realiza sem um devido planejamento que fixe “directrices globales definidas que después permitam contemplar la acción administrativa a medio y largo plazo, como respuesta coherente a un plan preconcebido y racionalizado"161.

Seja quem for que exerça tal atividade, isto é, mesmo quando não utilizados os instrumentos normativos previstos nos artigos 37, $\S \S 8^{\circ}$ e 9 e 241 da Constituição Federal, o objetivo da operação/coordenação será sempre o mesmo, isto é, a ordenação dos elementos e instrumentos de forma apta à realização do objetivo pretendido, bem como o planejamento harmônico das funções para que propicie, justamente, essa otimização dos esforços coletivamente considerados ${ }^{162}$.

O planejamento e o controle são pontos essenciais de preocupação de qualquer

\footnotetext{
${ }^{159}$ Conforme OSÓRIO, Fábio Medina. O "novo" sistema judicial brasileiro: significados e significantes. In: OSÓRIO, Fábio Medina; SOUTO, Marcos Juruena Villela (Coords). Direito administrativo: estudos em homenagem a Diogo de Figueiredo Moreira Neto. Rio de Janeiro: Lumen Juris, 2006. p. 66.

${ }^{160}$ COSTA, José Armando da. Teoria e prática do direito disciplinar, cit., p. 21.

${ }^{161}$ MARTÍN-RETORTILLO Y BAQUER. Sebastián. El reto de una administración racionalizada. Madrid: Civitas, 1983. p. 45.

${ }^{162}$ Sobre planejamento, ver CALHAO, Antônio Ernani Pedroso. O princípio da eficiência na administração da justiça. São Paulo: RCS Ed., 2007. p. 96-98 e MARTÍN-RETORTILLO Y BAQUER. Sebastián. op. cit., p. $42-52$ e 83.
} 
administrador moderno ${ }^{163}$. "O planejamento, em sua expressão mais simples, é a disposição racional de meios para atingir objetivos.",164

Esse tipo de planejamento foi brevemente tratado no Decreto-Lei $n^{\circ}$ 200/67 e constou de forma detalhada do plano de reforma realizado nos Estados Unidos da América, implementado pelo Government Performance Results Act of 1993, que prevê a elaboração de plano estratégico de programa de atividade em cada agência, no qual devem constar os objetivos, as missões de todas as funções da agência, a forma de se alcançar tais objetivos, com descrição do processo operacional, dos instrumentos tecnológicos, das habilidades, dos recursos humanos, capital e informações necessárias para a realização de tais objetivos, fazendo-se menção, inclusive, aos fatores externos que podem afetar suas realizações $(\text { seção } 3)^{165}$.

É preciso, portanto, acabar com a improvisação, com a ideia de que não há nenhum critério assumido para condução das atividades. É preciso estabelecer objetivos concretos e conferir meios para alcançá-los ${ }^{166}$. Para conferir harmonia, uniformidade, continuidade de desenvolvimento de tal atividade, há de haver referenciais que sirvam para articular os meios e os fins que constam no ordenamento jurídico, tais como metas de desempenho, técnicas de indicadores e outros ${ }^{167}$.

\subsubsection{Subjetivo}

$\mathrm{O}$ aspecto subjetivo consiste em evidenciar o elemento humano como parte importante para o alcance da eficiência.

O agente, além de fazer parte da organização, utiliza-se de todo aparato material como instrumento de alcance de suas competências; por isso, todos esses aspectos devem estar bem integrados, pois a falta ou o mau funcionamento de um deles pode colocar a

\footnotetext{
${ }^{163}$ Conforme DIAS, José de Nazaré Teixeira. A reforma administrativa de 1967, cit., p. 55 e 75.

${ }^{164}$ MOREIRA NETO, Diogo de Figueiredo. A lei de responsabilidade fiscal e seus princípios jurídicos, cit., p. 71-93.

${ }^{165}$ GOVERNMENT Performance Results Act of 1993. Disponível em: <http://www.whitehouse.gov/omb/mgmt-gpra/gplaw2m.html\#h9>. Acesso em: 19 fev. 2009.

${ }^{166}$ MARTÍN-RETORTILLO Y BAQUER. Sebastián. op. cit., p. 48 e 83.

${ }^{167}$ MOREIRA NETO, Diogo de Figueiredo. Uma nova administração pública. Revista de Direito Administrativo, Rio de Janeiro, n. 220, p. 179-182, abr./jun. 2000.
} 
perder toda a finalidade do sistema administrativo ${ }^{168}$, sempre lembrando que "as pessoas constituem o elemento inteligente e dinâmico que manipula, opera e agiliza todos esses recursos" $" 169$.

Nesse contexto, os agentes públicos deveriam gozar de maior liberdade para o alcance dos resultados, "o que o obriga a manejar instrumentos de negociação e persuasão, muito mais do que os instrumentos meramente formais de imposição de vontade unilateral", devendo agir de forma imparcial, técnica, alheia às questões políticas partidárias ${ }^{170}$.

Focando-se no elemento humano, é imprescindível, por exemplo, haver alocação e distribuição de recursos humanos de forma eficiente, "fazendo-se uma previsão do pessoal necessário à realização das funções próprias e permanentes" ${ }^{\# 11}$ da entidade pública e efetuando recrutamento contínuo por meio de pessoas especializadas em recrutar ${ }^{172}$. Isto é, "há que determinar o número, o tipo e as qualidades das pessoas físicas que são necessárias à permanente realização das tarefas e actividades impostas pela obrigatoriedade de prosseguir e assegurar a satisfação dos específicos fins públicos", por meio de quadros de pessoal, estando nestes, também, compreendidas exigências funcionais não uniformes, devendo o administrador estar atento a essa diversidade ${ }^{173}$.

Como concluem os cientistas da Administração, a eficiência de um órgão deve conduzir a um resultado de maior produtividade do que o decorrente da soma das contribuições individuais. A questão que se põe nesse segundo plano, portanto, diz respeito ao fato de que não basta a atuação individual eficiente do agente público tomado isoladamente, mas, para que o órgão ou unidade possa ser eficiente, é necessária a otimização das performances dos componentes isolados, além da eficiente coordenação e articulação desses esforços individuais. ${ }^{174}$

Quer dizer, o instrumento subjetivo compreende a articulação interpessoal ou interorgânica que deve almejar a junção dos esforços pessoais para a busca por um objetivo comum, tendo em vista que não basta uma atuação individual eficiente se não há união de esforços e articulação prévia desta para o alcance dos objetivos visados pelo grupo.

\footnotetext{
${ }^{168}$ SILVA, José Afonso da. Comentário contextual à Constituição. 5. ed. de acordo com a Emenda Constitucional 56, de 19.12.2007. São Paulo: Malheiros Ed., 2008. p. 337.

${ }^{169}$ CHIAVENATO, Idalberto. Administração dos novos tempos, cit., p. 4 e 14.

${ }^{170}$ OSÓRIO, Fábio Medina. Novos rumos da gestão pública brasileira: dificuldades. In: WAGNER JUNIOR, Luiz Guilherme Costa (Coord.). Direito público: estudos em homenagem ao professor Adílson Abreu Dallari. Belo Horizonte: Del Rey, 2004. p. 290-291.

${ }^{171}$ MOURA, Paulo Veiga e. op. cit., p. 60 e 65-66.

${ }^{172}$ DIAS, José de Nazaré Teixeira. op. cit., p. 69-70.

${ }^{173}$ MOURA, Paulo Veiga e. op. cit., p. 60 e 65-66.

${ }^{174}$ BATISTA JÚNIOR, Onofre Alves. op. cit., p. 265.
} 
Os agentes públicos são introduzidos na estrutura administrativa como parte essencial para o desenvolvimento da atividade estatal. Não é por outro motivo que a concepção burocrática já ressaltava a importância do papel por eles desempenhados. E esse aspecto subjetivo, embora reconhecido como de relevância ímpar, é subestimado pelos governantes que preferem redirecionar o foco de atenção na busca pela eficiência em outros aspectos da estrutura administrativa.

A conseqüência disso é o que geralmente se vê na Administração Pública, na qual os servidores concursados, originariamente qualificados, que entraram através de um concurso idôneo, com o tempo se desmotivam ao verificar que não há futuro para eles naquele espaço, se não for a partir da adesão a um determinado projeto político-partidário ou às relações de dependência pessoal. Isso gera uma brutal ineficiência de gestão ${ }^{175}$.

Isso nos leva a repensar se as mudanças necessárias para que haja uma máquina administrativa eficiente se encontram mesmo na lei ou na sua organização. Verifica-se que se trata muito mais de uma forma de agir do que algo que possa ser alterado mediante reformas jurídicas. Em muitas situações, o que é preciso ser mudado é o modelo de conduta dos agentes públicos, a vontade política ou os padrões culturais vigentes, não o modelo legal.

\subsubsection{Objetivo}

Com a assunção de diversas atividades garantidoras de um mínimo de dignidade aos administrados, o Estado, para dar atendimento a essa finalidade, ramificou-se de forma a passar a conter vários órgãos que perseguem os mais diversos fins (segurança, justiça, bem-estar econômico, social e cultural), passando a formar uma Administração Pública pluralista. Esses diversos fins devem ser articulados para o atendimento do bem comum, que é a finalidade primordial do Estado.

As finalidades dispostas na norma somente existem para atender o bem comum (interesse primário). Quer dizer, toda a escolha dos interesses secundários (aqueles que constam da norma) se pauta na finalidade de melhor atender ao bem comum.

\footnotetext{
${ }^{175}$ OSÓRIO, Fàbio Medina. O “novo” sistema judicial brasileiro: significados e significantes, cit., p. 67.
} 
O alcance do bem comum, por sua vez, somente ocorre com a devida articulação e a ponderação de todos os interesses presentes em cada caso concreto; a realização do bem comum da forma e da maneira adequadas é a conclusão de uma atuação eficiente ${ }^{176}$. “Assim, quando se diz que a Administração Pública deve observar o interesse público, não significa que deve atender ao interesse comum a todos os cidadãos, porque isto seria difícil, senão impossível. Ela deve atuar, justificadamente, de modo a beneficiar uma coletividade de pessoas que tenham interesses comuns"177.

Desse modo, a atuação administrativa eficiente não se coaduna com uma atuação focada em uma visão isolada e unilateral de um interesse primário. Daí a importância deste instrumento que visa ponderar e adequar todos os interesses secundários, constantes dos plexos de competências, à realização do interesse comum primário.

Então, para o alcance da finalidade primária, há necessidade de uma plena coordenação entre interesses em pauta e, consequentemente, entre os órgãos aos quais competem suprir tais interesses. Há necessidade de se tomar em consideração não a atuação isolada de um órgão ou um único interesse, mas a combinação da atividade de uma pluralidade de entes e de diversos interesses, pois, isoladamente, nenhuma estrutura organizacional e nenhum interesse satisfazem o complexo de interesses públicos ${ }^{178}$.

Portanto, também no aspecto do objeto perseguido pela administração pública, há evidente necessidade de haver uma operação coordenada no sentido de se alcançar, no final, o interesse de toda a coletividade.

\subsubsection{Material}

Não basta haver um belo sistema organizacional definido por lei, ótimos agentes públicos, providos de todos os conhecimentos técnicos necessários para o desenvolvimento de suas atividades, e ótima coordenação entre todos esses aspectos, se a Administração Pública não é dotada do aparato material necessário ao bom desenvolvimento das funções previstas na norma.

\footnotetext{
${ }^{176}$ Conforme BATISTA JÚNIOR, Onofre Alves. op. cit., p. 91-97.

${ }^{177}$ DI PIETRO, Maria Sylvia Zanella. Discricionariedade administrativa na Constituição de 1988, cit., p. 224.

${ }^{178}$ BATISTA JÚNIOR, Onofre Alves. op. cit., p. 69, 99, 493, 499, 661, 674-676.
} 
Nesse sentido, observou Felix Nigro:

Relação muito íntima existe entre o moral e a disciplina. Se os servidores estão satisfeitos com o trabalho terão, geralmente, um comportamento disciplinar. Por outro lado, como moral abatido, podem contrair maus hábitos. (...)

Todavia, as reprimendas e as medidas formais de disciplina nada resolverão. O descontentamento existe e é o que explica a conduta dos servidores. Punir sem remover a causa do mal-estar agravará a situação. A verdadeira causa é a debilitação do moral do grupo. Uma vez removidas as fontes geradoras dessa depressão, imediatamente mudará o comportamento dos servidores, que se concentrarão no serviço, como lhes cumpre. ${ }^{179}$

Não é preciso dizer como a questão financeira influencia, no plano imediato, esta situação $^{180}$. A baixa remuneração é fator de notório desestímulo. A distorção da remuneração dentro do próprio Estado, além de acarretar violação ao artigo $39, \S 1^{\circ}$ da Constituição Federal, acarreta preconceitos direcionados a todos os agentes, afetando, inclusive, os mal remunerados. Tais situações ensejam insatisfação e desalento dos funcionários, o que, evidentemente, afeta seu desempenho.

Não é por outro motivo que, para efetivar a profissionalização do servidor público, a Constituição Federal passou a prever, no artigo 39, a instituição de um Conselho de Política de Administração e Remuneração de Pessoal, a fim de que tal questão seja tratada de forma objetiva, isenta do corporativismo e de interesses políticos que normalmente regem tal questão.

Os estudos da Ciência da Administração, entretanto, concluem que "o pagamento e a recompensa salarial - mesmo quando efetuado em bases justas ou generosas - não é o único fator decisivo na satisfação do trabalhador dentro da situação de trabalho", podendo haver outras formas de motivação por meio de recompensas sociais, simbólicas e não materiais e outras que supram as necessidades ${ }^{181}$.

A frustração e o desestímulo podem se dar em diversas outras frentes, tal como a existência de critérios subjetivos para ascensão na carreira, privilégios de alguns em detrimento de outros, punições destemperadas ou ausência de punição ao agente desidioso,

\footnotetext{
${ }^{179}$ NIGRO, Felix. Administração de pessoal no serviço público. Trad. Maria de Lourdes Lima Modiano. Rio de Janeiro: Fundação Getúlio Vargas, 1966. p. 504.

180“'Y es ésta una realidad con la que hay que contar. La 'insatisfacción' de la función pública. Y hay que valorarla en una sociedad de consumo como la nuestra, en la que lo económico constituye un condicionante de extrema importancia." (MARTÍN-RETORTILLO Y BAQUER. Sebastián. op. cit., p. 53).

${ }^{181}$ CHIAVENATO, Idalberto. Introdução à teoria geral da administração, cit., p. 163-165.
} 
falta de treinamento, etc. São situações que muito contribuem para a ineficiência individual e, somadas, impactuam na prestação do serviço estatal como um todo. Isso porque "o moral baixo é acompanhado por uma atitude de desinteresse, negação, rejeição, pessimismo e apatia com relação ao trabalho e geralmente trazendo problemas de supervisão e de disciplina. Assim, o moral é uma consequência do grau de satisfação das necessidades individuais" $" 182$.

A moral é imprescindível para a dinâmica da administração, porque estimula o constante aperfeiçoamento profissional.

O moral elevado é acompanhado de uma atitude de interesse, de identificação, aceitação fácil, entusiasmo e impulso positivo em relação ao trabalho e geralmente em paralelo a uma diminuição dos problemas de supervisão e de disciplina. O moral elevado desenvolve a colaboração, porquanto ela se apóia em uma base psicológica onde predomina o desejo de pertencer e a satisfação de trabalhar em grupo. Depende invariavelmente do clima de relações humanas que se desenvolve dentro de uma organização, principalmente quando a organização formal permite um adequado entrosamento com a organização informal, quando as comunicações são de boa qualidade e o nível de supervisão é satisfatório. ${ }^{183}$

A movimentação na carreira também é instrumento importante de estímulo e se revela uma das melhores formas de contribuir para uma atuação eficiente, já que tal atuação pode contribuir para a ascensão ou para a estagnação do agente público ${ }^{184}$.

\subsubsection{Estrutural}

A Administração Pública deve fornecer o ambiente e a estrutura adequados para o exercício da atividade administrativa, não apenas como forma de valorizar o agente público, mas também para viabilizar o exercício pleno de suas atividades ${ }^{185}$. Tal estrutura, por sua vez, deve compreender o aspecto estrutural, como um ambiente de trabalho

\footnotetext{
${ }^{182}$ CHIAVENATO, Idalberto. Introdução à teoria geral da administração, cit., p. 171.

${ }^{183}$ Id. Ibid., p. 170.

184، A movimentação na carreira pela progressão funcional objetiva estimular o servidor a se tornar mais eficiente no serviço público.” (STJ, RMS 22866/MT, Ministro Felix Fischer, DJ 29/6/2007, p. 668).

${ }^{185}$ Em voto proferido pelo Ministro Carlos Britto no REQO 413.478, DJ 4/6/2004, p. 30, ele assim se manifestou: "o direito de greve se insere nos quadros do princípio da eficiência administrativa, ou seja, os servidores entram em greve não para se desgrudarem dos quadros estatais, ao contrário, proclamando que pretendem continuar na condição de servidores, porém, em melhores condições de trabalho para que o princípio da eficiência administrativa seja melhor servido".
} 
adequado, instrumentos de trabalho necessários e adequados para o desempenho da função específica de cada agente (como computadores para aqueles cuja atividade não os dispensa, por exemplo, escreventes, advogados públicos, juízes, promotores, etc., veículos para aqueles que exercem atividades externas, como fiscais, advogados públicos, etc., equipamentos para peritos, armas para policiais, etc). $\mathrm{O}$ material deve ser de qualidade e estar em bom estado de conservação propiciando o efetivo desempenho da função.

A estrutura deve compreender, também, o aspecto humano, consistente no número suficiente de agentes em determinado órgão, bem como a distribuição equânime do serviço, pois nada importa haver número suficiente de agentes se não há distribuição adequada do trabalho entre eles, sobrecarregando-se uns em prestígio de outros.

$\mathrm{Na}$ atividade individual e cotidiana do funcionário público, todos os aspectos ora mencionados são condicionantes para uma atuação eficiente, a fim de se proporcionar condições adequadas para a produção do ato administrativo.

\subsubsection{Intelectual}

Diogo de Figueiredo Moreira Neto afirma que, na atual Era das Comunicações, na qual a busca pelo conhecimento é o recurso básico para o desenvolvimento, "o seu acesso e a capacidade de utilizá-lo faz diferença importante na produção, transformação, circulação e distribuição de riquezas na sociedade que se está construindo hoje"186.

Destaca, José Pastore, que:

Tradicionalmente, a teoria econômica dividia o tempo do homem em duas partes: trabalho e lazer. Cada vez que ele, voluntariamente, diminuía o trabalho, aumentava o lazer e vice-versa. No mundo futuro, o seu tempo será dividido em três partes: trabalho, lazer e aprendizagem. $\mathrm{O}$ constante avanço da revolução tecnológica exigirá dos seres humanos a dedicação de uma grande parcela do seu tempo para apreender e dominar as inovações. Nesse mundo só haverá lugar para quem for capaz de apreender continuamente. Não haverá lei, sindicato ou partido que possa tornar atrativa aos empresários a mão-de-obra despreparada. ${ }^{187}$

\footnotetext{
${ }^{186}$ MOREIRA NETO, Diogo de Figueiredo. O Estado e o futuro: prospectiva sobre aspectos da instituição estatal. In: SOUZA, Hamilton Dias de (Coord.). A reengenharia do estado brasileiro. Apresentação Hamilton Dias de Souza. São Paulo: Ed. Revista dos Tribunais, 1995. p. 30.

${ }^{187}$ PASTORE, José. Redefinindo o que é trabalho. In: SOUZA, Hamilton Dias de (Org.). A reengenharia do Estado brasileiro. São Paulo: Ed. Revista dos Tribunais, 1995. p. 81-82.
} 
Por meio de tais entendimentos, é possível verificar a importância do aprendizado no mundo moderno, mormente por conta da dinâmica das mudanças técnicas promovidas em todas as ciências.

Não é por outro motivo que a Constituição Federal prevê alguns instrumentos que visam o treinamento e o aperfeiçoamento do funcionário público, tal como a instituição de escolas de governo para a formação e o aperfeiçoamento dos servidores públicos, a participação nos cursos como requisito para promoção na carreira e a aplicação de recursos no desenvolvimento de programas de qualidade e produtividade, treinamento $\mathrm{e}$ desenvolvimento, modernização, reaparelhamento e racionalização do serviço público, inclusive sob a forma de adicional ou prêmio de produtividade (artigo 39, §§ $2^{\circ}$ e $7^{\circ}$ ). A participação em tais cursos deve ser considerada na análise da promoção do funcionário ${ }^{188}$.

Tais escolas devem ampliar

o horizonte sistêmico de atuação (visão de conjunto do universo em que exercem ou exercerão funções, com suas interfaces definidas e exploradas), bem assim a compreensão do sentido político-administrativo do cargo e de suas funções (no âmbito do Poder em que inseridos e nas relações com os demais Poderes e com a Sociedade), de modo a torná-los aptos para encaminhar ou decidir, com adequação e presteza, legitimidade e economicidade, as questões atinentes às respectivas competências ${ }^{189}$.

A capacitação técnica dos funcionários é fator fundamental para que a atividade se desenvolva de forma eficiente. "Es necessario que os empleados posean las habilidades y el conocimiento requerido para desempeñar aquel puesto de trabajo que les ha sido asignado", ou seja, há a necessidade de se planejar a formação dos recursos humanos de forma pertinente às características das funções a serem exercidas por cada agente ${ }^{190}$.

Vê-se, portanto, que a atuação da Administração Pública direcionada ao funcionário público, como já falamos anteriormente, deve ser realizada de forma conjunta e integrada. Todos esses instrumentos previstos no texto constitucional, juntos, se afiguram, em tese, eficazes ao alcance da eficiência.

Um efetivo e eficaz investimento no aperfeiçoamento e treinamento do funcionário torna-o mais capacitado, reflete em uma maior segurança na sua atuação, bem como na

\footnotetext{
${ }^{188}$ Nesse sentido: STF, ADI 2879/ES, Ministro Cezar Peluso, DJ 4.6.2004, p. 28 e RE 27.246/DF, Ministro Afranio Costa, DJ 9/9/1955, p. 540.

${ }^{189}$ PEREIRA JUNIOR, Jessé Torres. Da reforma administrativa constitucional. Rio de Janeiro: Renovar, 1999. p. 208-209.

${ }^{190}$ SANCHO ROYO, David. Gestión de servicios públicos: estrategias de marketing y calidad, cit., p. 159.
} 
qualidade e na produtividade do serviço apresentado. Por outro lado, nada adiantam previsões legais que, apesar de se mostrarem aptas a uma efetiva mudança na dinâmica da Administração Pública, nunca foram efetivamente implantadas ou testadas, nem iniciativas isoladas, sem qualquer integração com um contexto do sistema inteiro.

\subsubsection{Moral}

A imoralidade também contribui para o desempenho e o resultado ineficientes da atuação administrativa, além dos evidentes prejuízos de ordem moral e material que acarreta. É que em um ambiente no qual predomina a moralidade, não há espaço para a ineficiência, porque o comportamento profissional dos agentes é direcionado tão somente para o atendimento das finalidades públicas, inexistindo desvio de objetivos. O contrário também se aplica.

Tanto é assim que o Decreto $\mathrm{n}^{\circ} 4.410$, de 7 de outubro de 2002, que promulga a Convenção Interamericana contra a Corrupção, estabelece como medida preventiva contra a corrupção, entre outras, a criação, o fortalecimento e a manutenção de "normas de conduta para o desempenho correto, honrado e adequado das funções públicas.”

Veja-se que a normatização aparece como forma de coibir condutas indevidas pelos funcionários públicos, visando suprir-lhes as dúvidas, as inseguranças e o completo desconhecimento das técnicas administrativas, que, inclusive, segundo Antonio Carlos Flores de Moraes, são os principais motivos da lentidão dos processos e da gestão incorreta e ineficaz do orçamento ${ }^{191}$.

Não é por outro motivo que a mencionada Convenção propõe, ainda, o estabelecimento de mecanismos para tornar efetivo o cumprimento dessas normas de conduta, bem como o estabelecimento de instruções ao pessoal dos órgãos públicos a fim de garantir o adequado entendimento de suas responsabilidades. Destaca, ainda, a importância dos sistemas de recrutamento de funcionários públicos e de aquisição de bens e serviços por parte do Estado, de forma a assegurar sua transparência, equidade e eficiência, bem como do desenvolvimento de estudo de novas medidas de prevenção, que

\footnotetext{
${ }^{191}$ MORAES, Antonio Carlos Flores de. Legalidade, eficiência e controle da administração pública. Belo Horizonte: Fórum, 2007. p. 207.
} 
levem em conta a relação entre uma remuneração equitativa e a probidade no serviço público.

Isso quer dizer que algumas medidas adotadas na Convenção Interamericana contra a Corrupção muito se aproximam daquelas defendidas para o alcance da eficiência, aproximando os institutos a ponto de se tornarem, de certa forma, interdependentes: com um sistema eficiente, coíbe-se a prática da corrupção, ao mesmo tempo em que a ausência de corrupção torna a Administração Pública mais eficiente. É que tanto a ineficiência como a corrupção enfraquecem as instituições, tornando o Estado vulnerável aos vícios morais e técnicos que ocorrem em um sistema viciado. Por isso é que a eficiência seria um novo domínio comportamental não intencional, porém violador dos cuidados objetivos e diligentes, que vem merecendo destaque na doutrina a ponto de sua relevância ser equiparada à corrupção ${ }^{192}$.

\subsubsection{Cultural}

Observa-se que a eficiência na Administração Pública possui diversas facetas, possuindo, também, uma vertente cultural. Na verdade, depende muito mais de uma mudança cultural de toda a sociedade e da atitude dos agentes públicos de todos os escalões para que ocorra sua efetivação no campo concreto, do que propriamente uma mudança em toda a normatização, a estrutura e sistemática utilizada atualmente pelo Estado ${ }^{193}$.

Por parte dos funcionários, há uma necessidade de haver uma mudança que provocasse a sensação de que são servidores do interesse geral, isto é, que sua razão de existência está em atender a coletividade ${ }^{194}$. Com relação aos administrados, é necessário que desenvolvam a consciência e o interesse no serviço público, participando do assunto e exercendo influência na busca pela eficiência na atividade administrativa ${ }^{195}$.

Talvez por tudo isso é que as reformas até hoje empreendidas não surtiram significativos efeitos concretos, apesar de, muitas vezes, direcionadas ao agente público. São as práticas invisíveis, a tentativa de se manter, na prática, o antigo regime, o

\footnotetext{
${ }^{192}$ Conforme OSÓRIO, Fábio Medina. Teoria da improbidade administrativa: má gestão pública, corrupção e ineficiência, cit., p. 36-37 e 71.

${ }^{193}$ Conforme RAMOS, Elival da Silva. A proteção aos direitos adquiridos no direito constitucional brasileiro. São Paulo: Saraiva, 2003. p. 250.

${ }^{194}$ Conforme MARTÍN-RETORTILLO Y BAQUER. Sebastián. op. cit., p. 301.

${ }^{195}$ Conforme DIAS, José de Nazaré Teixeira. A reforma administrativa de 1967, cit., p. 54-55.
} 
descompromisso com a sociedade ${ }^{196}$ e com os agentes públicos que acabam por impedir qualquer tentativa de mudança. Percebe-se que o alcance da eficiência está muito mais em alguns acertos pontuais, que se revelam evidentes e reconhecíveis por todos, do que na reforma jurídica da Administração Pública.

\subsection{Dever de eficiência do funcionário público}

Diante de tudo o que se expôs, percebe-se que a eficiência não é dever exclusivo e incondicionado do funcionário. Deve o empregador, isto é, o Estado, fornecer os meios materiais e psicológicos adequados para uma atuação eficiente, isto é, o dever de eficiência do funcionário público depende da eficiência da Administração Pública como um todo, principalmente em sua estrutura, na organização e coordenação.

Diante de tudo isso, conclui-se que a eficiência, como dever do agente público, deve ser sempre analisada de forma ampla e global, considerando-se todos os fatores que podem influenciar na atuação individual do agente.

Essa atuação individual, entretanto, apesar de ter que ser analisada de forma ampla, como acima proposto, não deixa de ser a principal questão a ser enfocada, quando se trata de ineficiência, porque são os funcionários públicos, individualmente considerados, que se relacionam com os administrados na representação do Estado, e porque, ao final, podem ser responsabilizados administrativamente por eventual ineficiência no exercício da administração pública.

$\mathrm{Na}$ verdade, não obstante todos os demais aspectos, é nessa atuação singularizada dos componentes da organização administrativa que a ineficiência se revela, se exterioriza; nessa atuação contínua daqueles que exercem o mister público em suas mais diversas ramificações, no trabalho singularizado de cada um, é que se forma um todo caminhante em direção ao sucesso ou fracasso da atividade.

Possui a eficiência, portanto, no que se refere à máquina administrativa, dois enfoques; o primeiro é aquele global, que consiste na eficiência como objetivo a ser alcançado mediante a integração de vários fatores e técnicas, como pessoal, organização, estrutura material, etc.; outro de aspecto individual, ou seja, da técnica a ser aplicada

\footnotetext{
${ }^{196}$ MORAES, Antonio Carlos Flores de. op. cit., p. 132.
} 
individualmente para a obtenção de melhor resultado no conjunto da atividade desenvolvida.

Sendo assim, o princípio da eficiência pode ser visto sob a ótica do modo de agir do agente público, esperando-se deste o melhor desempenho possível de suas atribuições, com a finalidade de alcançar os melhores resultados, e sob a ótica do modo de organizar, estruturar, disciplinar a Administração Pública, também com o mesmo fim de alcançar os melhores resultados na prestação do serviço público. ${ }^{197}$

$\mathrm{O}$ aspecto individual manifesta-se, primordialmente, pelas escolhas diárias que os agentes públicos fazem para o atendimento da finalidade da norma. No entanto, poderá se revelar, também, nas situações que não admitem escolhas. Merece, assim, a seguinte classificação: 1) eficiência na atuação que demanda escolha, ou seja, na atuação discricionária e 2) eficiência na atuação que não demanda escolhas, ou seja, na atuação vinculada.

\subsubsection{Atividade discricionária}

Advindo dos ideais libertários das revoluções do final do século XVIII, o princípio da legalidade, junto com o da Separação de Poderes, ingressou no ordenamento jurídico como forma de limitar os poderes do Estado, preservando-se as liberdades individuais tão almejadas à época. Por esse princípio, a atividade estatal haveria de estar subordinada às leis. A interferência do Estado na vida dos particulares ocorria apenas de forma excepcional, de forma negativa, quer dizer, voltada primordialmente para evitar perturbação da ordem pública, da liberdade, da propriedade e da segurança individual.

A submissão da Administração Pública ao império das leis representa a observância da vontade do povo e de um sistema normativo estático, genérico e abstrato, que preserva determinados direitos individuais tidos como absolutos contra os desmandos do Estado.

O princípio da legalidade, no que se refere à Administração Pública, se exprime de maneira muito mais restrita que o regime existente para os particulares, no qual vigora a autonomia da vontade. Estes podem fazer tudo o que não for proibido por lei, enquanto a Administração Pública somente pode fazer aquilo que está contido na lei. O sentido de

\footnotetext{
${ }^{197}$ SANTOS, Alvacir Correa dos. op. cit., p. 255.
} 
legalidade é positivo, sendo a atuação da Administração Pública realizada sempre em nível infralegal.

Cumpre, no Estado de Direito, que os administrados estejam, de antemão, assegurados de que o proceder administrativo não lhes causará surpresas. E não as causará tanto porque outros fins, que não os estabelecidos em lei, estão vedados ao administrador, quanto porque estes mesmos fins só podem ser alcançados pelas vias previstas na regra de Direito como as adequadas ao caso. ${ }^{198}$

Já naquela época, procurava-se compatibilizar a legalidade com a ideia de discricionariedade, advinda do Estado de Polícia, pois, "como resquício do período anterior, das monarquias absolutas, continuou-se a reconhecer à Administração Pública uma esfera de atuação livre de vinculação à lei e livre de qualquer controle judicial"199 .

A complexização das ordens social, econômica e jurídica fez com que outros valores, coletivamente considerados, passassem a merecer a proteção do ordenamento jurídico, a fim de garantir o perfeito desenvolvimento da coletividade. Assim, ampliou-se o conceito de legalidade, incluindo-se, nele, os princípios que integram o ordenamento jurídico e compõem-se como seu alicerce.

O sistema piramidal de hierarquia de normas, apresentado por Hans Kelsen, demonstra como se relacionam as normas existentes no atual ordenamento jurídico. As normas que se localizam em faixas inferiores devem respeitar aquelas que se localizam em faixas superiores, aumentando-se a quantidade de normas a serem observadas quanto mais baixa for a localização da norma na estrutura piramidal ${ }^{200}$, inclusive as decisões individuais. No topo da pirâmide se encontra a Constituição e, por conseguinte, seus princípios.

O princípio da legalidade, entretanto, embora presente de forma ostensiva na atuação administrativa, não subordina toda a atividade do Estado à mera execução das leis, pois isso seria inviável; primeiro, porque é impossível ao legislador prever e regular todas as situações passíveis de atuação do Estado, depois, porque levaria a Administração Pública ao automatismo. Nesse sentido, a própria lei possui aberturas que permitem a atuação da Administração Pública sem vinculação expressa.

Assim, no desempenho da atividade executiva que, inicialmente, guarda o sentido

\footnotetext{
${ }^{198}$ MELLO, Celso Antônio Bandeira de. Discricionariedade e controle jurisdicional. 2. ed., 7. tir., São Paulo: Malheiros Ed., 2006. p. 60.

${ }^{199}$ DI PIETRO, Maria Sylvia Zanella. Discricionariedade administrativa na Constituição de 1988, cit., p. 26.

${ }^{200}$ KELSEN, Hans. Teoria pura do direito, cit., p. 285-289 e 309-319.
} 
de execução do conteúdo da lei, é preciso, justamente para cumprir tal mister, fazer escolhas que a própria lei autoriza, ainda que implicitamente, contendo-se, entretanto, nos limites por ela mesma traçados. Desta forma, pode-se afirmar: “A Administração é uma função essencialmente executiva: encontra na lei o fundamento e o limite da sua actividade"201.

Com o aumento da atividade estatal decorrente da instituição do Estado-Providência pela Constituição Federal de 1988, que previu inúmeros direitos sociais para os cidadãos, maior se fez a necessidade de se deixar à Administração Pública as decisões administrativas que visassem otimizar a realização dos mesmos. Somente a flexibilização e a agilidade próprias do conhecimento específico do Poder Executivo quanto à máquina administrativa, dos recursos existentes e das necessidades prementes é que atenderiam, da melhor forma, as infinitas, complexas, crescentes e cambiantes necessidades coletivas.

Portanto, a existência deste sistema de discricionariedade visa, sobretudo, o atingimento do resultado eficiente e de forma eficiente. Ou seja, o próprio sistema contém em si a previsão implícita da eficiência ${ }^{202}$, na medida em que a omissão da lei apenas se justifica para que sejam adotadas as providências que possam oferecer a verdadeira satisfação à finalidade legal; “decisões eficientes pressupõem sempre serem opções livres" ${ }^{203}$; é nisso que consiste a discricionariedade.

A discricionariedade, portanto, relaciona-se intimamente com o ideal de eficiência, tendo em vista que ambos objetivam a opção pela melhor solução para que a atividade administrativa seja exercida da melhor forma possível; ambos visam o alcance do interesse público mediante a aplicação da boa administração ${ }^{204}$.

A discricionariedade, como poder instrumental, consiste no poder-dever da Administração Pública de escolher, quando a lei permite, dentre várias opções possíveis, todas igualmente válidas para o ordenamento jurídico, aquela que melhor atenda à finalidade da lei e, consequentemente, o interesse público. Portanto, ela "só se justifica

\footnotetext{
${ }^{201}$ RIVERO, Jean. op. cit., p. 20.

${ }^{202} \mathrm{O}$ dever de boa administração está implícito na discricionariedade. (MOREIRA NETO, Diogo de Figueiredo. Legitimidade e discricionariedade: novas reflexões sobre os limites e controle da discricionariedade. Obra premiada em $1^{\circ}$ lugar pela Ordem dos Advogados do Brasil - RJ - Prêmio "José Ribeiro de Castro Filho". 2. ed. Rio de Janeiro: Forense, 1991. p. 26).

${ }^{203}$ MOREIRA NETO, Diogo de Figueiredo. Reinstitucionalização da ordem econômica. 4. painel (Apresentado no XVII Congresso Brasileiro de Direito Constitucional). Cadernos de Direito Constitucional e Ciência Política, São Paulo, v. 5, n. 18, p. 87-95, jan./mar. 1997.

${ }^{204}$ Conforme MARTINS JUNIOR, Wallace Paiva. A discricionariedade administrativa à luz do princípio da eficiência. Revista dos Tribunais, São Paulo, ano 90, v. 789, p. 62-89, jul. 2001.
} 
como garantia de concretização das finalidades assinaladas pelo ordenamento jurídico",205 da melhor forma possível.

O princípio da eficiência atua visando encontrar "a forma mais eficiente de cumprir a lei, e deve buscar, entre as soluções teoricamente possíveis, aquela que, diante das circunstâncias do caso concreto, permita atingir os resultados necessários à melhor satisfação do interesse público",206.

Assim, a discricionariedade e a eficiência agem da mesma forma, sendo certo que o conceito de uma se liga ao de outra ${ }^{207}$.

E, nesse sentido, "será eficiente a Administração quando cumprir a lei, sobretudo na competência discricionária. A opção terá que ser a melhor possível, em face do atendimento da finalidade da lei." 208

Sob este aspecto, o princípio da eficiência pode ser visto como um predicado do princípio da legalidade ${ }^{209}$, isto é, o princípio da eficiência visa "embeber a legalidade de uma nova lógica, determinando a insurgência de uma legalidade finalística e material - dos resultados práticos alcançados -, e não mais uma legalidade meramente formal e abstrata" 210 .

Portanto, o próprio exercício regular da discricionariedade acaba por acarretar o cumprimento da eficiência, a ponto de Heraldo Garcia Vitta afirmar:

A bem da verdade, tudo se resolve no cumprimento da lei. Mais uma vez o referido princípio, com o qual nos ocupamos, não serve para dar alicerce jurídico às normas, constitucionais ou legais - mas acabou confirmando a exigência constitucional de uma administração voltada para o dever (jurídico) de bem servir a todos (dever jurídico de boa administração), com o qual o exercício da competência discricionária tem especial relevo. A melhor opção, no caso concreto, deverá nortear a conduta do administrador. ${ }^{211}$

\footnotetext{
${ }^{205}$ FIGUEIREDO, Lúcia Valle. Curso de direito administrativo. 8. ed. rev., ampl. e atual. São Paulo: Malheiros Ed., 2006. p. 232.

${ }^{206}$ DALLARI, Adilson Abreu. Privatização, eficiência e responsabilidade, cit., p. 220.

${ }^{207}$ FALZONE, Guido. op. cit., p. 65, 70-72, 86, 110-111 e 114-115 e FREITAS, Juarez. Discricionariedade administrativa e o direito fundamental à boa administração pública, cit., p. 22.

${ }^{208}$ VITTA, Heraldo Garcia. O princípio da eficiência e a discrição administrativa. Revista do Instituto de Pesquisas e Estudos, Bauru, n. 36, p. 405-407, dez./abr. 2002-2003.

${ }^{209}$ MODESTO, Paulo. Notas para um debate sobre o princípio constitucional da eficiência, cit.

${ }^{210}$ ARAGÃO, Alexandre Santos. O princípio da eficiência, cit., p. 1-6.

${ }^{211}$ VITTA, Heraldo Garcia. O princípio da eficiência e a discrição administrativa, cit., p. 405-407.
} 


\subsubsection{Conceito jurídico indeterminado}

Associado com a questão da discricionariedade encontra-se o ponto referente aos conceitos jurídicos indeterminados.

Conceito jurídico indeterminado é aquele estabelecido por meio de expressões abertas sem precisão de conotação, que torna impreciso o enquadramento de determinadas situações fáticas ao conteúdo da norma. "Nesse caso, não há dúvida sobre o sentido da palavra, mas sobre seu alcance."212

No direito administrativo, muito se discute se o enquadramento de determinado fato a uma determinada norma, constituída por conceito jurídico indeterminado, seria um exercício de discricionariedade ou de interpretação. No primeiro caso, não poderia o Poder Judiciário intervir, podendo, no último, pois a interpretação admitiria apenas uma solução possível. Isso porque o que distinguiria a discricionariedade e a interpretação seria "a relevância da vontade do agente aplicador da norma naquela e a ausência de apreciação subjetiva nesta",213.

Gustavo Bineboun afirma que a discricionariedade e os conceitos jurídicos indeterminados, embora ambos traduzam abertura das normas, se diferenciam porque na primeira é conferido um poder de escolha ao administrador, e nos segundos não há uma opção do administrador; se há uma eleição, esta é do próprio legislador, sendo que sua aplicação resolve-se com a interpretação de seu sentido. Reconhece, entretanto, a existência de um núcleo preciso de significado e um halo periférico de penumbra, no qual há uma certa margem de apreciação na interpretação por parte do Poder Público ${ }^{214}$.

O Supremo Tribunal Federal já se manifestou no sentido de que os conceitos jurídicos indeterminados não representam autorização para o exercício da discricionariedade pela Administração Pública, sendo certo "que a autoridade administrativa está autorizada a atuar discricionariamente apenas, única e exclusivamente, quando norma jurídica válida expressamente a ela atribuir essa livre atuação". Por outro

\footnotetext{
${ }^{212}$ DAL BOSCO, Maria Goretti Dal. Responsabilidade do agente público por ato de improbidade. Rio de Janeiro: Lumen Juris, 2004. p. 66.

${ }^{213}$ COSTA, Regina Helena. Conceitos jurídicos indeterminados e discricionariedade administrativa. Revista de Direito Público, São Paulo, ano 23, n. 95, jul./set. 1990.

${ }^{214}$ BINENBOUN, Gustavo. Uma teoria do direito administrativo. Rio de Janeiro: Renovar, 2006. p. $216-219$.
} 
lado, também afastou a existência de simples interpretação com uma única solução, isto é, reconheceu que inexiste uma interpretação verdadeira (única correta) nestes $\operatorname{casos}^{215}$.

Analisando-se a questão, pode-se concluir, portanto, que tanto o ato de volição como o de intelecção, isto é, tanto a discricionariedade quanto a interpretação, possuem a mesma ressonância jurídica, ou seja, ambas chegam a um conteúdo mínimo e unânime do conceito e ambas excluem as soluções inviáveis ${ }^{216}$, principalmente quando em confronto com a realidade e os fatos concretos, de forma que se torna desnecessário estabelecer a diferença entre eles.

Celso Antônio Bandeira de Mello explica essa conclusão: diante de um conceito indeterminado sempre haverá uma zona de certeza positiva de circunstâncias às quais o conceito se aplica e uma zona de certeza negativa de circunstâncias que certamente não são englobadas pelo conceito, de forma que a discricionariedade fica restrita apenas às circunstâncias que não se enquadram em nenhuma destas zonas, nas quais existe dúvida (zona circundante) $)^{217}$. Nesse sentido, a liberdade de atuação do administrador, somente quando não contida na zona de incerteza, pode sofrer controle pelo Poder Judiciário ${ }^{218}$.

Nesse sentido: "a função e o sentido da estipulação legal de conceitos jurídicos indeterminados são absolutamente idênticos aos da atribuição de discricionariedade", pois a finalidade de ambos é que o administrador adote a solução ótima para o caso concreto ${ }^{219}$.

Tais ensinamentos também se aplicam ao próprio conceito de eficiência que, inequivocadamente, é um conceito jurídico indeterminado, no qual se reconhece uma margem de livre apreciação e outra de conteúdo definido.

Assim, de tudo que se expôs, conclui-se que não há solução rígida para a questão, isto é, o conceito jurídico indeterminado pode induzir à discricionariedade ou à vinculação, dependendo do caso concreto e do tipo de conceito utilizado na norma ${ }^{220}$, sendo certo, entretanto, que, independentemente de se agir de forma interpretativa ou discricionária, o resultado é que sempre haverá um conteúdo mínimo certo e uma zona de incerteza remanescente, zona esta na qual a Administração Pública pode agir com liberdade.

\footnotetext{
${ }^{215}$ RMS 24699/DF, Ministro Eros Grau, DJ 1/7/2005, p. 56.

${ }^{216}$ MELLO, Celso Antônio Bandeira de. Discricionariedade e controle jurisdicional, cit., p. 25.

${ }^{217}$ Id. Ibid., p. 29.

${ }^{218}$ STF, RE 167.137/TO, Ministro Paulo Brossard, 25/11/1994, p. 840.

${ }^{219}$ PEREIRA, Cesar A. Guimarães. Discricionariedade e apreciações técnicas da administração. Revista de Direito Administrativo, Rio de Janeiro, n. 231, p. 217-267, jan./mar. 2003.

${ }^{220}$ BASTOS, Aline Maria Dias. Conceitos jurídicos indeterminados: discricionariedade ou vinculação? 2002. Dissertação (Mestrado) - Faculdade de Direito, Universidade de São Paulo, São Paulo, 2002. p. 201.
} 


\subsubsection{Discricionariedade técnica}

Ao Poder Executivo foi atribuída a função residual "à qual estão atribuídos todos os misteres de organização concreta da sociedade, tudo afinal que se relacione com a atividade de gestão dos interesses da coletividade", sendo que, em tal função, alojam-se "atividades de perfil eminentemente técnico - aquelas que dependem de conhecimentos especiais para seu desempenho e de profissionais com real aptidão para desenvolvê-las"221.

Discricionariedade técnica se relaciona à análise do caso concreto, que encontra solução mediante a aplicação de conhecimento técnico científico, decorrente de regras médicas, de engenharia, biológicas, isto é, a solução apropriada, em função de conceito formulado pela lei, requer uma valoração técnica com base em alguma ciência ${ }^{222}$.

Para a maioria da doutrina, o conceito técnico não seria conceito jurídico indeterminado e nem comportaria exercício de discricionariedade, na medida em que a solução a ser adotada seria aquela escolhida de acordo com os parâmetros técnicos, isto é, de acordo com a respectiva ciência.

Nesse sentido, Hely Lopes Meirelles entende que "a técnica é, hoje, inseparável da Administração e se impõe como fator vinculante em todos os serviços públicos especializados, sem admitir discricionarismos ou opções burocráticas nos setores em que a segurança, a funcionalidade e o rendimento dependam de normas e métodos científicos de comprovada eficiência". É nisso, inclusive, que consiste a eficiência para ele: aplicação do critério técnico destinado à solução de um assunto específico ou opção por uma alternativa técnica, quando várias lhe são apresentadas ${ }^{223}$.

Lembra, entretanto, Marçal Justen Filho, que, ainda que a opção do administrador tenha que se basear em uma concepção técnica, não há ciência que gere aplicações práticas absolutamente precisas, uniformes e destituídas de alternativas e dúvidas. O conhecimento técnico apenas delimita as alternativas e o juízo de oportunidade e conveniência é utilizado dentro da margem de escolha remanescente ${ }^{224}$.

Utilizando-se deste raciocínio, tem-se que as apreciações técnicas da Administração

\footnotetext{
${ }^{221}$ CARVALHO FILHO, José dos Santos. A discricionariedade: análise de seu delineamento jurídico. In: GARCIA, Emerson (Coord.). Discricionariedade administrativa. Rio de Janeiro: Lumen Juris, 2005. p. 33.

${ }^{222}$ BASTOS, Aline Maria Dias. op. cit., p. 92-93.

${ }^{223}$ MEIRELLES, Hely Lopes. Direito administrativo brasileiro, cit., p. 109.

${ }^{224}$ JUSTEN FILHO, Marçal. Curso de direito administrativo, cit., p. 158-159.
} 
não se diferenciam de outras manifestações por ela emanadas. Quer dizer, "podem ou não envolver discricionariedade, segundo critérios idênticos aos aplicáveis a qualquer outro caso de desempenho de função administrativa" e, quando envolvem, a forma de solução não é diferente daquela utilizada na discricionariedade. "O mecanismo de atuação da discrição é o mesmo em todas as situações", isto é, haverá discricionariedade quando houver incerteza científica ${ }^{225}$.

Desse modo, com relação aos atos administrativos, o tema não envolve maior dificuldade: se o conceito indeterminado contido na lei puder tornar-se determinado pela manifestação de órgão técnico, com base em conhecimentos científicos, não se pode falar em discricionariedade propriamente dita, sendo dado ao Poder Judiciário rever a decisão da Administração Pública. ${ }^{226}$

Assim, a solução parece se conduzir, mais uma vez, para o critério das zonas de certezas e incertezas, que colabora para a realização de uma atuação administrativa ótima, pelo qual estabelece-se um núcleo certo que delimita a atuação do Estado, quando não o conduz para uma única solução ${ }^{227}$, e uma zona de incerteza, na qual o Estado age com liberdade.

\subsubsection{Procedimento administrativo}

O nascimento do procedimento administrativo se deu juntamente com a submissão do Estado ao princípio da legalidade, como exigência social de se impor formas préestabelecidas que garantissem a liberdade do indivíduo. Sofreu, entretanto, desprestígio com a crise liberal e com a fuga para o regime privado.

A fuga do sistema burocrático teve como consequência lógica a ideia de afastamento dos procedimentos, buscando-se uma administração pautada nos resultados; os meios foram relegados a segundo plano.

No entanto, como forma de realização das finalidades do Estado Social e Democrático, o procedimento, no âmbito administrativo e na atualidade, se reergueu a um

\footnotetext{
${ }^{225}$ PEREIRA, Cesar A. Guimarães. op. cit., p. 217-267.

${ }^{226}$ DI PIETRO, Maria Sylvia Zanella. Discricionariedade técnica e discricionariedade administrativa. Revista Brasileira de Direito Público - RBDP, Belo Horizonte, ano 5, n. 17, p. 75-96, abr./jun. 2007.

${ }^{227}$ Conforme FRANÇA, Vladimir da Rocha. Eficiência administrativa na Constituição Federal. Revista de Direito Administrativo, Rio de Janeiro, n. 220, p. 165-177, abr./jun. 2000.
} 
nível de relevância ímpar por ultrapassar a função de administrar interesses contrapostos e se revelando como meio apto e adequado à formação do ato administrativo, que hoje merece indiscutível atenção em face do alargamento da interferência estatal no âmbito social e econômico, decorrente da ampliação das funções por ele assumidas ${ }^{228}$.

Assim, atualmente, o processo administrativo serve tanto para atender aos interesses dos particulares e da boa gestão, por meio do formalismo que lhe é característico, bem como atender com celeridade às exigências impostas pelas necessidades da sociedade ${ }^{229}$.

Sob este novo prisma, o processo se revela como um meio de garantir um melhor conteúdo das decisões adotadas pela Administração Pública, concatenando de forma adequada os elementos que culminam com a decisão. Afigura-se, portanto, como garantia dos administrados, na medida em que cada etapa é qualificada por uma motivação, cuja soma culmina com o ato final. Dessa forma, é possível se assegurar os limites materiais da atuação da Administração Pública, na medida em que esse método permite a construção gradual da motivação, obrigando que cada opção seja paulatinamente indicada no processo, tornando-a explícita e facilitando o controle. Isso porque as fases e o seu conteúdo devem guardar coerência com o resultado escolhido pela Administração Pública, o que facilita o controle da Administração Pública ${ }^{230}$.

A atuação estatal se exprimirá, no processo, por meio de fases, das quais o particular participa, contribuindo para a determinação do fato ou da situação objeto do processo e ampliando os pressupostos objetivos da decisão administrativa. Esse processo exprime paridade e imparcialidade e propicia o sopesamento dos vários interesses envolvidos em uma situação.

E, nesse contexto, se mostra irrefutável que a participação social no procedimento é um dos mais importantes mecanismos de cumprimento da eficiência na atuação discricionária da Administração Pública $^{231}$, na medida em que permite o fluxo de

\footnotetext{
228“No quadro da hipercomplexidade das sociedades hodiernas, o procedimento parece ser a resposta adequada para alargar a capacidade de decisão do sistema." (LOUREIRO, João Carlos Simões Gonçalves. O procedimento administrativo entre a eficiência e a garantia dos particulares: algumas considerações. Boletim da Faculdade de Direito Universidade de Coimbra, Coimbra, p. 70, 1995).

${ }^{229}$ HARGER, Marcelo. Princípios constitucionais do processo administrativo. 2. ed. rev. e atual. Rio de Janeiro: Forense; Gen, 2008. p. 128.

${ }^{230}$ MEDAUAR, Odete. Direito administrativo moderno, cit., p. 163.

${ }^{231}$ VALLE, Vanice Lírio do. Direito fundamental à boa administração, políticas públicas eficientes e prevenção do desgoverno, cit., p. 87-109.
} 
informações, isto é, expõe o administrador a elementos não considerados inicialmente ${ }^{232}$, atribuindo qualidade às decisões e atos administrativos.

Assim, o procedimento de formação do ato administrativo passa a ser visto como uma forma de proteção dos administrados, além de propiciar uma atuação administrativa mais eficiente e transparente. Trata-se, neste sentido, de uma forma de contrabalançar a garantia e a eficiência, a proteção do cidadão e a modernização administrativa, a celeridade e a economicidade e o cumprimento de metas e a justiça social ${ }^{233}$.

É por isso que o procedimento é reconhecido como "meio para o fomento da aplicação do princípio da eficiência”, na medida em que não apenas garante a observância dos direitos dos administrados, como, também, eleva "a qualidade da decisão tomada, pela simples consideração da existência de alternativas, além de aproximar o resultado das intenções do legislador ao determinar a competência do agente" ${ }^{\text {234 }}$.

$\mathrm{Na}$ linha de se alcançar o equilíbrio acima propugnado, tem-se a legislação específica (Lei federal n 9.784, de 29 de janeiro de 1999 e Lei estadual no 10.177, de 30 de dezembro de 1998 e algumas disposições esparsas como, por exemplo, o artigo 12, IV e 13, da Lei $n^{\circ} 11.079$, de 30 de dezembro de 2004), que dinamiza, democratiza e aperfeiçoa a atuação estatal, tornando o instrumento da atuação administrativa mais eficiente.

Como se vê, apesar de a eficiência ter sido incorporada à realidade constitucional tendo como mote a melhoria da prestação do serviço público, acabou ganhando no tema "processo administrativo" interessantes locubrações teóricas. Talvez isto ocorra justamente porque o cerne da atividade administrativa do Estado Moderno contemporâneo se manifeste através do procedimento e seja neste que a averiguação da eficiência se torne mais recorrente. ${ }^{235}$

\subsubsection{Atividade vinculada}

Vimos que há uma verdadeira intersecção de conteúdo, ou coincidência, até mesmo, entre a discricionariedade e a eficiência, já que o exercício da primeira e a aplicação da

\footnotetext{
${ }^{232}$ ADAMI, Mateus Piva. A discricionariedade administrativa em face do princípio da eficiência, cit., p. 93.

${ }^{233}$ Conforme MONTEIRO, Vera. As leis de procedimento administrativo: uma leitura operacional do princípio constitucional da eficiência. In: SUNDFELD, Carlos Ari; MUÑOZ, Guilhermo Andrés (Coords.). As leis de processo administrativo (Lei federal 9.784/99 e Lei paulista 10.177/98). 1. ed. 2.tir. São Paulo: Malheiros Ed., 2006. p. 342-363, p. 363 e BACELLAR FILHO, Romeu Felipe. Princípios constitucionais do processo administrativo disciplinar. São Paulo: Max Limonad, 1998. p. 168.

${ }^{234}$ ADAMI, Mateus Piva. op. cit., p. 10 e 93.

${ }^{235}$ GABARDO, Emerson. op. cit., p. 119.
} 
segunda acabam por acarretar a mesma consequência: a busca pela melhor solução, de forma que a introdução do princípio da eficiência apenas teria confirmado (embora desnecessariamente) que o agente público, na competência discricionária, deve fazer a escolha que melhor atenda ao interesse público $^{236}$. Assim, uma atividade é inerente à outra; quando uma não existe, a outra também não existirá.

Isso nos faz pensar se a introdução do princípio da eficiência no ordenamento jurídico teria sido, de fato, destinada à atuação discricionária da Administração Pública. Verifica-se, em razão da coincidência de finalidades, que a discricionariedade e a eficiência se equivalem, de forma que se conclui que, talvez, a introdução do princípio da eficiência tenha visado, na verdade, muito mais as atividades vinculadas da Administração Pública do que a atividade discricionária, muito embora essa abordagem seja difícil de ser encontrada na doutrina.

O poder vinculado é o contraposto ao poder discricionário. Todas as etapas e elementos do ato administrativo vinculado são previstos objetivamente em lei, não podendo o agente público agir de forma diferente, ou seja, não há qualquer liberdade de escolha. Em havendo determinado fato previsto em lei, deve a Administração Pública aplicar a consequência jurídica indicada para tal fato. Neste caso, a busca pela melhor solução no caso concreto não parte e nem mesmo incumbe à Administração Pública, pois é matéria já superada na elaboração da lei, isto é, é o legislador que considera o comportamento vinculado o mais eficiente, ainda que não o seja efetivamente.

Mesmo quando a lei for ineficiente, o servidor não pode deixar de aplicá-la, porque está adstrito ao princípio da legalidade, cabendo somente ao Poder Judiciário a competência para declaração de inconstitucionalidade da lei, pois o exercício vinculado da atividade administrativa, como já vimos, não oferece margem de escolhas ao administrador.

Tal vinculação não garante, entretanto, condutas e resultados eficientes. É, aliás, muito outra a avaliação que os administrados fazem da atuação rotineira dos agentes públicos que se encontram na linha de frente, na execução vinculada da lei.

Muitas vezes, a ineficiência se encontra justamente no exercício de funções cujo plexo de competência não inclui atividade discricionária. Falamos da maioria dos funcionários do Estado que atuam somente como executores, em atividades completamente ligadas à lei, sem qualquer permissivo de escolha, o que comprova que não é apenas a

\footnotetext{
${ }^{236}$ Conforme VITTA, Heraldo Garcia. O princípio da eficiência e a discrição administrativa, cit., p. 405-407.
} 
atividade discricionária que deve se pautar pela eficiência.

$\mathrm{Na}$ atividade vinculada o legislador pode fixar os meios (instrumentos) e os fins (interesses) da competência, sendo, entretanto, que o manuseio destas determinações, a atuação, a execução podem não se revelar satisfatórios, exsurgindo, daí, a ineficiência.

Nesse sentido, na atividade vinculada, a eficiência seria o dever de melhor adimplemento da finalidade pública através do uso idôneo e correto dos meios fornecidos pela lei. A deficiência no meio de atuação vinculada do agente público pode ser constatada pela utilização errada dos instrumentos dispostos na lei, que acaba por prejudicar os aspectos qualitativo, quantitativo e temporal do ato. Na atividade vinculada, a eficiência se expressaria, portanto, pelo meio de atuação dos agentes, quer dizer, na articulação dos meios disponíveis, na utilização dos instrumentos e no grau de atuação dos agentes públicos $^{237}$.

Tal entendimento coincide com o conceito de Hely Lopes Meirelles sobre a eficiência, para quem seria o dever imposto a todo agente público consistente em realizar suas funções com presteza, perfeição e rendimento funcional ${ }^{238}$.

O Código de Ética Profissional do Servidor Público Civil do Poder Executivo Federal, Decreto n ${ }^{\circ} 1.171$, de 22 de junho de 1994, por sua vez, prevê como dever funcional do servidor público “exercer suas atribuições com rapidez, perfeição e rendimento, pondo fim ou procurando prioritariamente resolver situações procrastinatórias, principalmente diante de filas ou de qualquer outra espécie de atraso na prestação dos serviços pelo setor em que exerça suas atribuições, com o fim de evitar dano moral ao usuário” (seção II, XIV, “b”).

Podemos, portanto, dividir a eficiência da atividade vinculada em três aspectos: celeridade, quantidade e qualidade. Vejamos.

\subsubsection{Celeridade}

O Superior Tribunal de Justiça em diversos acórdãos reconhece a relação existente entre a eficiência e a celeridade ${ }^{239}$.

\footnotetext{
${ }^{237}$ BATISTA JÚNIOR, Onofre Alves. Princípio constitucional da eficiência administrativa, cit., p. 224,478 e 682.

${ }^{238}$ MEIRELLES, Hely Lopes. op. cit., p. 108-109.

${ }^{239}$ STJ, Resp. 687.947-MS, Ministro Castro Meira, Ministra Eliana Calmon e o Ministro João Otávio de Noronha, DJ 16.2.2006; Resp. 983077/SC, Ministra Eliana Calmon, DJ 27/11/2008; MS 13545/DF, Ministra Maria Thereza de Assis Moura, DJ 07/11/2008; MS 13322/DF, Ministro José Delgado, DJ
} 
"A celeridade impõe que os atos processuais sejam praticados no mais curto espaço de tempo possível, de forma contínua e coordenada"; não devem, ainda, se revestir de formalidades extravagantes, detalhes secundários ou repetições desnecessárias para o alcance de seu objetivo $^{240}$.

A celeridade é um dos aspectos que mais se relaciona com as discussões acerca de um processo administrativo eficiente, na medida em que a solução intempestiva de determinada situação, muitas vezes, pode não surtir os efeitos desejados que surtiria se realizada em tempo menor ou adequado. Esse aspecto ressalta o perfil qualitativo do ato. No entanto, se se partir do pressuposto de que a atividade mais célere acarreta a produção de um maior número de atos, a celeridade acaba por acarretar consequências no aspecto quantitativo.

Não é por outro motivo que a Emenda Constitucional no 45/2004 dispôs que "a todos, no âmbito judicial e administrativo, são assegurados a razoável duração do processo e os meios que garantem a celeridade de sua tramitação", por meio da introdução do inciso LXXVIII do artigo $5^{\circ}$ da Constituição Federal.

Qualifica-se este viés da eficiência pelo alcance rápido de resultados de uma determinada ação, mensurando-se tal rapidez em razão da finalidade e dos meios empregados. Assim, a prestação célere do serviço pelo agente é aquela que se realiza como se não tivesse havido obstáculo algum a sua consecuçãa ${ }^{241}$.

A duração razoável do processo significa que deve ser suficiente para sua conclusão adequada, podendo ser considerados oscritérios utilizados pela Corte Europeia de Direitos Humanos, tais como a complexidade das questões envolvidas, o comportamento das partes

16/06/2008; Resp. 1044158/MS, Ministro Castro Meira, DJ 06/06/2008; Resp. 1031533/MS, Ministro Castro Meira, DJ 16/05/2008; MS 12847/DF, Ministro Hamilton Carvalhido, DJ 05/08/2008; MS 7765/DF, Ministro Paulo Medina, DJ 14/10/2002, p. 183; MS 10792/DF, Ministro Hamilton Carvalhido, DJ 21/8/2006, p. 228; Resp. 579020/AL, Ministro José Delgado, DJ 5/11/2008; Resp. 690811/RS, Ministro José Delgado, DJ 19/12/2005, p. 234; Resp. 690819/RS, Ministro José Delgado, DJ 19/12/1995, p. 234; Resp. 983.659/MS, Ministro José Delgado, DJ 6/3/2008; Resp. 980.271/SC, Ministro José Delgado, DJ 3/3/2008; MS 12376/Df, Ministro Herman Benjamin, DJ 1/9/2008; MS 9420/DF, Ministra Laurita Vaz, DJ 6/9/2004, p. 163; Resp. 529304/RS, Ministro José Delgado, DJ 9/8/2004, p. 174; Resp. 531349/RS, Ministro José Delgado, DJ 9/8/2004, p. 174; Resp. 608918, Ministro José Delgado, DJ 21/6/2004, p. 176; MS 9190/DF, Minsitro Luiz Fux, DJ 15/12/2003, p. 175; Resp. 549253/RS, Ministro Eliana Calmon, DJ 15/12/2003, p. 283; MS 9061/DF, Ministro Teori Albino Zavascki, DJ 24/11/2003, p. 212.

${ }^{240}$ MOREIRA, Egon Bockmann. Processo administrativo: princípios constitucionais e a Lei 9.784/1999, cit., p. 197, 200 e 203.

${ }^{24}$ MARTINS, Alzemeri; SOUZA, Marisa Idalência de. O princípio constitucional da eficiência, aplicação à função do Procurador do Estado no exercício da consultoria jurídica, cit., p. 59-98. 
e a conduta dos julgadores ${ }^{242}$.

Cumpre lembrar, por fim, que a Lei Estadual do Estado de São Paulo nº 10.177, de 30 de dezembro de 1998, prevê a responsabilidade disciplinar aos agentes públicos que não cumprirem os prazos de referida lei.

\subsubsection{Quantidade}

O aspecto quantitativo é o mais fácil de ser mensurado e verificado, na medida em que comporta aferição objetiva, mediante a análise da quantidade daquilo que se produziu.

A produtividade, tida como a quantificação daquilo que se produz, é reconhecida como um dos aspectos da eficiência ${ }^{243}$. É evidente que, assim como todos os demais aspectos da eficiência, a produtividade não pode ser considerada de forma isolada, pois seu alcance pode ocorrer com evidentes prejuízos de outros aspectos da eficiência. Quer dizer, o produto final pode ter baixa qualidade, justamente por visar a quantidade.

\subsubsection{Qualidade}

A qualidade da atividade e do resultado final implica na observância de todos os princípios administrativos, na observância de todos os outros aspectos acima tratados, bem como de outros comportamentos que trataremos adiante.

Veja-se que em acórdão do Supremo Tribunal Federal identificou-se a estreita relação entre eficiência e outros princípios como o da impessoalidade, moralidade e igualdade, porque constituem "condição ou requisito indispensável da eficiência operacional da administração pública" ${ }^{244}$.

\footnotetext{
${ }^{242}$ Rocha, tratando do processo civil em raciocínio que também aplica se ao processo administrativo, trata da questão. (ROCHA, Silvio Luís Ferreira da. Duração razoável dos processos judiciais e administrativos. Interesse Público, v. 8, n. 39, p. 73-80, 2006).

${ }^{243}$ STJ, Resp. 581.073-MG, Relator Ministro Arnaldo Esteves Lima, DJ 11.12.2006, p. 409.

${ }^{244}$ ADC-MC 12/DF, voto do Ministro Cezar Peluso, no qual afirma, entretanto, entender que a eficiência não chega a ser princípio, DJ 1/9/2006, p. 15.
} 
Beatriz Tomás Mallén menciona que, na comunidade Europeia, um dos aspectos da "boa administração" é o direito a um trato administrativo imparcial e equitativo, significando o mais amplo princípio de objetividade a serviço dos interesses gerais ${ }^{245}$.

Nesse sentido, a Administração Pública deve estabelecer regras do jogo justas com isenção na valoração de interesses em conflito ${ }^{246}$, levando em conta apenas as exigências do interesse geral, sem favoritismo, como exemplo, estabelecer ordem de atendimento e tratamento dos administrados baseados na igualdade.

Outro aspecto inerente à qualidade é o dever de perfeição, que significa precisão, isto é, o "máximo de excelência que uma coisa pode chegar; primor; correção"247.

Segundo Diogenes Gasparini: “As atribuições devem ser executadas com perfeição, valendo-se das técnicas e conhecimentos necessários a tornar a execução a melhor possível, evitando sua repetição e reclamos por parte dos administrados"248.

Ercson Meister Scorsim fala em regularidade, continuidade e segurança dos serviços públicos, características que também não podem faltar na atividade típica e essencial do Estado ${ }^{249}$.

A ausência de continuidade é outro aspecto que leva à ineficiência da atividade administrativa. “A atuação da Administração Pública não pode ser intermitente, incerta, instável. Por força de sua essencialidade, ela deve ser constante, permanente, sempre funcionando, sempre disponível para seus destinatários." ${ }^{, 250}$. Nesse sentido, entre outras coisas, a Administração deve levar a cabo as ações já iniciadas ${ }^{251}$.

E, ligado ao conceito de continuidade, podemos acrescentar o da capacidade de mudança permanente para se adaptar às progressivas e aceleradas alterações das necessidades sociais, consubstanciada na adoção de meios que permitam seguir e

\footnotetext{
${ }^{245}$ TOMÁS MALLÉN, Beatriz. El derecho fundamental a una buena administración. 1. ed. Madrid: Instituto Nacional de Administração Pública, 2004. (Estudios). p. 184 e 266-270.

${ }^{246}$ BARBOSA, Sandra Pires. Impacto da globalização sobre o princípio da eficiência. Revista de Direito Administrativo, Rio de Janeiro, n. 224, p. 197-210, abr./jun. 2001.

${ }^{247}$ Conforme Dicionário Aurélio.

${ }^{248}$ GASPARINI, Diógenes. Direito administrativo. 9. ed. São Paulo: Saraiva, 2004. p. 20-21.

${ }^{249}$ SCORSIM, Ericson Meister. Os serviços públicos e o princípio da eficiência. $B D A$ : boletim de direito administrativo, São Paulo, v. 18, n. 3, p. 193-200, mar. 2002.

${ }^{250}$ DALLARI, Adilson Abreu. Administração pública no estado de direito, cit., p. 33-41.

${ }^{251}$ MARTÍN-RETORTILLO Y BAQUER. Sebastián. op. cit., p. 68.
} 
administrar a mudança e estimular a capacidade de aprender e inovar dos servidores ${ }^{252}$, mantendo a continuidade do serviço em seu sentido amplo.

Nesse sentido, o que deve ser enfatizado "é a melhoria permanente, ou seja, no dia seguinte, a qualidade será ainda melhor" ${ }^{253}$. "Para ser eficiente, portanto, é forçoso estar em ininterrupto processo de aperfeiçoamento, renovando-se e atuando com agilidade."

Há, ainda, a cortesia, prevista nos artigos $6^{\circ}, \S 1^{\circ}$ da Lei $n^{\circ} 8.987$, de 13 de fevereiro de 1995, 17 da Lei paulista $n^{\circ} 7.835$, de 8 de maio de 1992 e $7^{\circ}$, I da Lei paulista $\mathrm{n}^{\circ} 10.294$, de 20 de abril de 1999.

Dinorá Adelaide Musetti Grotti assim define a cortesia:

O princípio da cortesia traduz-se em bom acolhimento ao público. Impõem-se a quem presta um serviço público um tratamento urbano, civilizado, sem o menosprezo daquele que se considera dono da coisa pública, prevalecendo-se do poder que lhe foi atribuído, tal como se estivesse prestando um favor aos usuários. ${ }^{255}$

Tem-se, ainda, diversas outras característica do aspecto da qualidade, como a boa vontade, a educação, objetividade, clareza, profissionalização, informatização, transparência, etc.

Enfim, são inúmeras as características que ensejam uma atuação de qualidade, sendo importante, porém não obrigatório, que elas sejam legalmente estabelecidas de forma objetiva a fim de pautar a atuação estatal, como dito anteriormente.

A Portaria $\mathrm{n}^{\mathrm{o}}$ 705, de 14 de novembro de 1991, do Presidente do Comitê Nacional da Qualidade e Produtividade, Secretário Geral do Presidente da República, menciona que, pela qualidade "busca-se a otimização dos resultados pela aplicação de certa quantidade de recursos e esforços, incluída no resultado otimizado, primordialmente, a satisfação proporcionada ao consumidor, cliente ou usuário".

\footnotetext{
${ }^{252}$ SANTAMARIA PASTOR, Juan Alfonso. Estado social de derecho y control jurídico de eficacia de la administración pública, cit., p. 165-179.

${ }^{253}$ Apud MALKUT, Rozeli Aparecida da Silva. O princípio da eficiência na Administração Pública brasileira. Revista Jurídica do UNIARAXÁ, v. 8, n. 7, 2004.

${ }^{254}$ NIEBUHR, Joel de Menezes. Princípio da eficiência. Revista Trimestral de Direito Público, São Paulo, n. 30, p. 134-140, 2000.

${ }^{255}$ GROTTI, Dinorá Adelaide Musetti. O serviço público e a Constituição brasileira de 1988. São Paulo: Malheiros Ed., 2003. p. 299.
} 
Se o dever de boa administração, traduzido como eficiência, se realiza com satisfação plena do interesse público ${ }^{256}$, é possível concluir que a qualidade da atividade pública estará presente sempre que o administrado se sentir satisfeito. Assim, haverá respeito à eficiência sempre que "o administrado se sente amparado e satisfeito na resolução dos problemas que ininterruptamente leva à Administração" ${ }^{257}$.

${ }^{256}$ Conforme MOREIRA NETO, Diogo de Figueiredo. Legitimidade e discricionariedade: novas reflexões sobre os limites e controle da discricionariedade, cit., p. 30.

${ }^{257}$ FRANÇA, Vladimir da Rocha. Eficiência administrativa na Constituição Federal, cit., p. 165-177. 


\section{CAPÍTULO 3. RESPONSABILIDADE ADMINISTRATIVA DO FUNCIONÁRIO PÚBLICO POR INEFICIÊNCIA}

\subsection{Finalidade da pena disciplinar}

Vimos, na introdução, que a sanção é a consequência juridicamente estabelecida em virtude da não observância de alguma regra legal que é obrigatória ou da realização de algum comportamento previsto como infração em lei. Essas regras obrigatórias ou proibitivas, que possuem previsão de sanção, são inseridas no ordenamento jurídico com o fito de se preservar determinados valores e se manter determinadas ordens.

Em todos os grupos humanos formados natural ou voluntàriamente para a realização de certos fins se torna necessária a observância pelos respectivos participantes das normas de conduta imprescindíveis à coesão e à eficiência do grupo. (...)

Quanto mais preciso e próximo é o objetivo a atingir por um grupo de homens, mais concretas e rigorosas têm de ser as normas que os unem e os guiam. Essas normas formam a disciplina do grupo e a sua inobservância origina a indisciplina. ${ }^{258}$

Para haver disciplina, deve haver sanção. Todas as sanções são retributivas porque, se não fossem, não surtiriam qualquer resultado; portanto, este seria o efeito da sanção, e não sua finalidade. A finalidade é o objetivo que pretendem alcançar com a aplicação da sanção ${ }^{259}$.

A finalidade da pena não pode ser analisada sem qualquer associação com a finalidade da própria atividade que se pretende preservar com a sua prescrição. "Isso porque a causa final de qualquer ser especifica sua razão de existir, e nas ciências morais ou práticas, que têm por objeto o ser humano e seu comportamento - isto é, princípios que ordenam a conduta humana -, o fim dessas relações cumpre ser considerado", isto é, "a causa final está ínsita no próprio ser"260.

\footnotetext{
${ }^{258}$ CAETANO, Marcello. Manual de direito administrativo, cit., v. 2, p. 799.

${ }^{259}$ VITTA, Heraldo Garcia. A sanção no direito administrativo, cit., p. 63 e MELLO, Rafael Munhoz de. Princípios constitucionais de direito administrativo sancionar: as sanções administrativas à luz da Constituição Federal de 1988, cit., p. 76 e 255.

${ }^{260}$ MELLO, Oswaldo Aranha Bandeira de. Princípios gerais de direito administrativo. Rio de Janeiro: Forense, 1969. v. 2, p. 214.
} 
Assim, antes de verificarmos a finalidade da pena disciplinar, discorreremos, brevemente, sobre a finalidade da pena nas áreas que com ela se relacionam de alguma forma.

\subsubsection{Finalidade da pena no campo criminal}

No âmbito penal, onde se encontra a essência de todas as sanções, a Exposição de Motivos do Código Penal fundamenta a aplicação da pena, imprimindo-lhe um caráter social-intimidativo e corretivo, visando a prevenção de delitos e o reajustamento social do delinqüente. Assim, a pena criminal tem a função de prevenção geral e prevenção especial.

A prevenção geral visa "a intimidação aos demais indivíduos para que, mediante a ameaça da aplicação da pena, não transgridam as regras que lhes impõe Estado" e a prevenção especial evita "que o próprio homem que delinqüiu volte a cometer novas condutas reprováveis do ponto de vista penal, tendo assim o objetivo de livrar a sociedade do convívio maléfico daquele que pode oferecer riscos à sua segurança" ${ }^{\text {261 }}$. Há ainda a função ressocializadora, pela qual se busca reeducar o indivíduo, oferecendo-lhe a oportunidade de reabilitar-se ao convívio social ${ }^{262}$.

A prevenção geral se divide em negativa e positiva. A primeira seria a própria previsão do crime e de sua respectiva pena, que possuem força intimidatória pela potencial possibilidade de ser aplicada. A prevenção geral positiva é a confiança da sociedade de que a pena será aplicada quando a ordem normativa for violada, ou seja, é a confiança no sistema ${ }^{263}$.

A prevenção especial, que "é a ação do Estado voltada a impedir que alguém já condenado por um crime volte a delinqüir", também se manifesta de forma negativa e positiva.

Prevenção especial negativa é o uso da força do Estado e de seu poder de intimidação. Como forma de impedir que o condenado volte a delinqüir, o Estado, por um certo período de tempo, priva-o de sua liberdade ou the impede o acesso a cargos públicos, por exemplo. Ao mesmo tempo, o Estado aumenta a carga negativa de sua intimidação para este indivíduo

\footnotetext{
${ }^{261}$ FREITAS, Izaías Dantas. A finalidade da pena no processo administrativo disciplinar. Boletim de Direito Administrativo, São Paulo, ano 17, n. 8, p. 618-625, ago. 2001.

${ }^{262}$ Id. Ibid., p. 618-625.

${ }^{263}$ CINTRA, Adjair de Andrade. Prescrição penal e finalidades da pena. 2007. Dissertação (Mestrado) Faculdade de Direito, Universidade de São Paulo, São Paulo, 2007. p. 34-35 e 42.
} 
em especial, ao prescrever que a reincidência tornará a pena aplicada ainda mais severa.

Já a prevenção especial positiva é a ação do Estado no sentido de integrar à sociedade aquele que descumpriu suas regras de convivência. Isso é feito de várias formas, como a progressividade no regime de cumprimento da pena, de forma a fazer com que o condenado volte gradativamente ao convívio social, e a possibilidade de o condenado, apenas teoricamente nos dias de hoje, continuar seus estudos, se profissionalizar, passar por um acompanhamento psicológico no período que esteve privado de sua liberdade, dentre outras medidas possíveis que o tempo de privação de liberdade em algo positivo para o condenado. ${ }^{264}$

\subsubsection{Finalidade da pena no campo administrativo}

Em relação à pena administrativa, segmento da qual a pena disciplinar faz parte, Marcelo Madureira Prates afirma que a sanção administrativa tem duas finalidades: deixar claro para todos os administrados quais os comportamentos que não são admitidos (o que ele chama de prevenção negativa geral e especial) e reforçar a importância da norma violada e obter a colaboração dos administrados no alcance do interesse público (o que chama de prevenção geral positiva) ${ }^{265}$.

\subsubsection{Finalidade da pena no campo laboral}

Reitere-se que o poder disciplinar não é fenômeno exclusivo da Administração Pública, já que "ele é encontrado em todos os agrupamentos humanos, sejam naturais ou voluntários", que queiram "manter coesão e eficiência", como a família, as associações em

geral, as empresas privadas, as ordens religiosas, enfim, em todo o grupo humano ${ }^{266}$. No caso, é pela existência do aspecto profissional que a sanção disciplinar-administrativa se relaciona com a do campo laboral.

No âmbito laboral, ressalta-se a existência do caráter pedagógico da sanção disciplinar:

\footnotetext{
${ }^{264}$ CINTRA, Adjair de Andrade. op. cit., p. 37-38.

${ }^{265}$ PRATES, Marcelo Madureira. Sanção administrativa geral: anatomia e autonomia, cit., p. 128-130.

${ }^{266}$ LAZZARINI, Álvaro. Estudos de direito administrativo. São Paulo: Ed. Revista dos Tribunais, 1999. p. 398.
} 
A doutrina e a jurisprudência elegem, ainda, o caráter pedagógico do exercício do poder disciplinar como importante critério informador da aplicação de penas no contexto empregatício. Considera-se fundamental que o poder punitivo seja exercido com a finalidade de ajustar o obreiro à sadia convivência laborativa, em um contexto de regras lícitas adotadas pela empresa. O objetivo central de tal poder não seria sancionar, apenar, mas principalmente criar condições para a ressocialização obreira no universo empresarial. A punição deve ser encarada apenas como instrumento subordinado a esse objetivo maior, do mesmo modo que a exclusão do trabalhador do emprego deve ser tida como solução cabível somente em casos efetivamente justificáveis. ${ }^{267}$

Evidentemente este caráter pedagógico não é exclusivo, tendo em vista que a finalidade da pena se apoia, ainda, na repressão do próprio autor da infração, para evitar que repita a falta, e na prevenção com relação aos demais empregados, instituindo-se exemplo para que outros não cometam a falta, a exemplo do que ocorre no direito penal ${ }^{268}$.

\subsubsection{Finalidade da pena no campo administrativo-disciplinar}

Percebe-se, pelo que se expôs, que as penas em todos os âmbitos sancionatórios demonstrados têm as mesmas finalidades, na medida em que a manutenção da ordem é da essência de qualquer sanção.

Assim, a pena disciplinar, no plano geral, atua da seguinte forma: desestímulo do infrator à repetição da infração; desestímulo à prática das condutas censuradas pelas demais pessoas, mediante o exemplo da punição; afastamento do infrator da ordem que se pretende manter, evitando-se, assim que ele cause mais prejuízos e para que a ordem se mantenha sem vícios; e correção do infrator, mediante o reajuste de sua conduta, de forma a permitir seu o retorno e a sua manutenção na ordem da qual foi excluído em igualdade de condições das demais pessoas (ressocialização).

Vimos que o poder disciplinar decorre da necessidade de ordem e equilíbrio nas relações humanas, da necessidade de alcance de uma ordem justa na vida em comunidade; é uma necessidade social, de direito natural, própria do agregado humano ${ }^{269}$.

\footnotetext{
${ }^{267}$ DELGADO, Mauricio Godinho. Curso de direito do trabalho. 6. ed. São Paulo: LTr, 2007. p. 678.

${ }^{268}$ KRAUSPENHAR, Rogério. Os limites do poder disciplinar do empregador. São Paulo: LTr, 2001. p. 26.

${ }^{269}$ BARROS JÚNIOR, Carlos S. de. Do poder disciplinar na administração pública. 1969. Tese (Cátedra de Direito Administrativo) - Faculdade de Direito da Universidade de São Paulo, São Paulo, 1969. p. 6 e 62.
} 
No âmbito de uma organização pública, se destina à perfeição do fím que a atividade persegue, regendo todos os atos dos agentes. "O poder disciplinar tem, portanto, sua origem e razão de ser no interêsse e na necessidade de aperfeiçoamento progressivo do serviço público., ${ }^{, 270}$

Nesse sentido, exemplifica Marcello Caetano que, se uma peça não funciona, o maquinário se ressente, retardando seus movimentos e diminuindo seu rendimento. Assim, o maquinário deve ser reparado por meio da tentativa de reintegrar o agente na pluralidade da função, por meio de sanções medicinais que corrigem e estimulem, na esperança da emenda. Se não for possível a emenda por incapacidade ou inadaptabilidade de força, aí sim deve-se expulsá-lo ${ }^{271}$.

Se o poder disciplinar e, por consequência, a sanção disciplinar visam a regularidade e o contínuo aperfeiçoamento da atividade administrativa, é considerado um importante instrumento para o alcance da eficiência, devendo ser priorizado sempre o caráter educativo da pena.

\subsection{Poder disciplinar como instrumento de cumprimento do dever de eficiência}

É consenso doutrinário que o objetivo do poder disciplinar dirigido aos funcionários públicos é o aperfeiçoamento progressivo e o bom andamento da atividade pública, é a boa administração, a disciplina interna da administração $0^{272}$.

Portanto, logo se vê que a finalidade do poder disciplinar se liga estreitamente com a eficiência na atuação administrativa, já que, por meio dele, se pretende evitar comportamentos individuais que comprometam o desenvolvimento eficiente da atividade pública, isto é, que comprometam a "coesão do grupo",273. "Desta forma, através da acção imediata sobre os agentes, a aplicação das penas disciplinares tem por fim defender o serviço da indisciplina e melhorar o seu funcionamento e eficiência, mantendo-o fiel aos

\footnotetext{
${ }^{270}$ CAETANO, Marcelo. Do poder disciplinar no direito administrativo português. Coimbra: Imprensa da Universidade, 1932. p. 25.

${ }^{271}$ Id. Ibid., p. 23 e 35.

${ }^{272}$ GARCIA, Mônica Nicida. Responsabilidade do agente público. Belo Horizonte: Fórum, 2007. p. 237.

${ }^{273}$ BRANDÃO, Cláudio. Poder disciplinar: um direito penal administrativo? Revista da Esmape- Escola Superior da Magistratura do Estado de Pernambuco, v. 3, n. 7, p. 83-102, jan./jun. 1998.
} 
seus fins",274.

É evidente que a eficiência, como já vimos, se realiza de diversas maneiras, de forma que a aplicação da pena não pode desestimular atitudes inovadoras e criativas que, em um ambiente saudável, se desenvolvem como incremento da qualidade e produtividade da atividade.

Sabe-se que as amarras inerentes à estrutura estatal e a deficiência na organização e na coordenação, já demonstradas, contêm certos impedimentos que desencorajam a apresentação de novidades que contribuam para um melhor desempenho administrativo ou que solucionem determinados problemas. O exercício do poder disciplinar não pode agir da mesma forma. Onofre Alves Batista Batista Júnior resume tal entendimento da seguinte maneira:

\begin{abstract}
Verificamos também que o comportamento que, em nome da eficiência, buscar superar as barreiras referenciais hierárquicas e das normas internas no caso concreto, pode esbarrar em dificuldades de todas as ordens. A busca da eficiência, muitas vezes, pode mesmo ser um convite para repercussões negativas para o agente, e o resultado pode ser a generalização de um comportamento mediano, resignado, de baixo perfil, no qual o mais prudente talvez seja não ousar, esconder-se por trás das normas internas e diretrizes, ou até não fazer nada. Enfim, o modelo de AP conspira mesmo contra o PE, em detrimento da sociedade. ${ }^{275}$
\end{abstract}

Não há dúvidas de que "a disciplina é uma das colunas mestras em que repousa a eficiência da Pública Administração" ${ }^{\text {276 }}$, mas a aplicação da pena não deve ser mais um fator de inibição das condutas praticadas com intuito positivo, pois, assim, estaria atuando justamente contra o objetivo que visa alcançar e os valores que visa proteger.

Deve-se sempre reforçar a ideia de que deve haver uma visão ampla de todo o sistema e a integração dos mais variados institutos, a fim de se alcançar com eficiência a finalidade pública buscada pelo Estado. Por isso, não se pode deixar de destacar a relevância do papel do poder punitivo nesse processo de integração de esforços e medidas em prol do desenvolvimento de uma atividade eficiente.

\footnotetext{
${ }^{274}$ CAETANO, Marcello. Manual de direito administrativo, cit., v. 2, p. 819.

${ }^{275}$ BATISTA JÚNIOR, Onofre Alves. op. cit., p. 579.

${ }^{276}$ LAZZARINI, Álvaro. op. cit., p. 387.
} 


\subsubsection{Poder disciplinar como fator de desestímulo dos funcionários públicos}

O fator de desestímulo do poder disciplinar pode ser visto por meio de dois planos: o primeiro se revela na ausência de aplicação de penas quando necessário, o que implica na consequente inobservância dos deveres e proibições pelos funcionários e acarreta uma verdadeira anarquia institucional.

Como observou Lúcia Valle Figueiredo, a não apenação afeta a respeitabilidade, a governabilidade e a credibilidade da Administração Pública ${ }^{277}$.

O segundo aspecto é justamente o contrário, qual seja, o da penalização desponderada, que acaba por engessar a atividade administrativa, impedindo processos criativos, criando insatisfação nos funcionário e acarretando desestrutura no ambiente de trabalho. Um ambiente de fiscalização ostensiva e punição excessiva deixa de ser saudável e o desempenho dos funcionários é evidentemente atingido por esta situação. "A vítima direta de tais desatinos é o funcionário injustiçado, mas a coletividade, embora reflexamente, é a grande prejudicada. O Serviço Público sofre o desgaste e o descrédito, saindo vitorioso apenas o mau administrador, que fica impune e, às vezes, glorificado ou temido, embora falsamente admirado., 278

Portanto, a ausência de punição adequada e a punição inadequada acabam por acarretar um desestímulo no exercício da atividade desenvolvida pelos agentes públicos, já que alimentam a sensação de que não há controle efetivo ou justo.

É por isso que o poder disciplinar, que, como vimos, é um braço do poder punitivo do Estado, dever ser exercido de forma eficiente, com propósito de equilíbrio e boa realização, sob pena de desvirtuar a sua finalidade.

Para tanto, o poder sancionador do Estado não deve ser entendido como uma faculdade da Administração Pública, senão mesmo como um dever. Por isso que o primeiro pressuposto para que o sistema funcione de forma eficiente é o cumprimento estrito deste dever, pois somente assim o administrado encontrará justiça, igualdade e segurança, já que o funcionamento correto do sistema lhe conferirá parâmetros nos quais deve pautar sua

\footnotetext{
${ }^{277}$ FIGUEIREDO, Lucia Valle. Responsabilidade dos agentes políticos e dos servidores. Revista de Direito Administrativo, Rio de Janeiro, n. 196, p. 36-42, abr./jun. 1994.

${ }^{278}$ COSTA, José Armando da. Teoria e prática do direito disciplinar, cit., p. 10.
} 
conduta $^{279}$ e lhe dará a certeza de que todos serão tratados da mesma forma. É por isso que se diz que a Administração Pública tem o "dever-poder" 280 de apurar os ilícitos administrativos praticados por aqueles que se subordinam a sua disciplina interna e aplicar as respectivas penalidades.

Há quem entenda que a Administração Pública detém discricionariedade no sentido de iniciar, continuar ou não a apuração de uma determinada infração ou aplicar ou não a respectiva pena, quando houver outros interesses públicos preponderantes sobre o interesse sancionador ou quando presente a inconveniência de se movimentar o aparelho administrativo em função da baixa reprovação que merecerá o ilícito concretamente praticado. Nesse sentido, Oswaldo Aranha Bandeira de Mello, Carlos S. de Barros Júnior e Marcello Caetano, referem-se ao poder disciplinar, sendo que o primeiro acredita que, ao invés de ser punido, o agente pode exonerar-se a pedido, ressarcindo os prejuízos, ou, ainda, pode deixar de ser aplicada a pena conforme interesses superiores, como, por exemplo, quando a aplicação da sanção gerar descrédito para a Administração Pública, e, o último, acrescenta que a repressão disciplinar somente deve ser aplicada quando a vantagem da punição for maior para a boa ordem do serviço do que o esquecimento da falta $^{281}$.

Tal ideia, entretanto, contrasta com a opinião de Cesare Bonesana Beccaria, dirigida para os delitos criminais ao tratar do perdão, mas que perfeitamente se encaixa na discussão ora proposta. Para ele, tal ideia contraria o interesse público, na medida em que destrói a necessidade do exemplo. $\mathrm{O}$ direito de castigar não pertenceria a qualquer um em particular; é das leis, pertence à vontade geral, e, por isso, há de ser exercido ${ }^{282}$.

Sem dúvida, em um sistema perfeito, a proposta inicial se afiguraria a mais eficiente, em seu conteúdo moderno e econômico, na medida em que considera o custo e benefício da aplicação da pena em todos os seus aspectos. Por outro lado, no presente grau de evolução da prática punitiva do Estado, tendo em conta todas as mazelas do sistema apontadas no presente trabalho e diante da realidade proposta no atual momento histórico, a

\footnotetext{
${ }^{279}$ Conforme BECCARIA, Cesare Bonesana. Dos delitos e das penas. Trad. Deocleciano Torrieri Guimarães. São Paulo: Rideel, 2003. p. 24 e 78.

${ }^{280}$ Segundo Mello, os poderes dos quais é investido o Estado têm caráter meramente instrumental, ou seja, servem apenas para que seja cumprido o dever de se efetivar o interesse público, que nada mais é do que a razão pela qual o Estado foi investido nos poderes atribuídos. (MELLO, Celso Antônio Bandeira de. Curso de direito administrativo, cit., p. 46 e 143).

${ }^{281}$ MELLO, Oswaldo Aranha Bandeira de. Princípios gerais de direito administrativo: introdução, cit., v. 2 , p. 141; BARROS JÚNIOR, Carlos S. de. op. cit., p. 25-27. e CAETANO, Marcello. Do poder disciplinar no direito administrativo português, cit., p. 44.

${ }^{282}$ BECCARIA, Cesare Bonesana. op. cit., p. 79.
} 
segunda solução se apresenta mais viável, pois, se, até mesmo sem a autorização da lei, o que se vê com recorrência é a ausência de punição de funcionários que cometem infrações, por diversos motivos, inclusive culturais, a situação se complicaria se houvesse autorização para que a autoridade agisse com discricionariedade neste sentido. Ademais, na ponderação de valores, é certo que, ao final, deve prevalecer o da indisponibilidade do interesse público, que pugna pela penalização daquele que violar as regras destinadas ao alcance do interesse público ${ }^{283}$.

Ademais, deve-se considerar para a análise da questão a observação feita por JesúsMaria Silva Sánchez, no sentido de que outro fator que contribui para que o sistema seja eficiente é a "probabilidade de que a pena se faça efetiva". Segundo ela, "se há algo que desmotiva o delinquiente potencial é a elevada probabilidade de ser descoberto e punido, mais do que a pena em si”,284.

Acrescentaa Cesare Bonesana Beccaria que o infrator deve ser prontamente castigado pelo delito cometido, para que desperte em todos a ideia de um castigo inevitável, já que a punição retardada faz afastar as ideias de crime e punição do sentimento humano. Além disso, o castigo deve guardar conformidade com a natureza do crime, para que o temor de uma punição especial afaste a possibilidade de um crime vantajoso ${ }^{285}$.

Certamente, a questão da agilidade da aplicação da punição é muito importante no sistema de aplicação da pena pelo motivo apontado pelo autor, mas também para não se dilargar o castigo no tempo. Não apenas a pena em si representa punição, o processo de sua aplicação e a perda das vantagens decorrentes dele também implicam sofrimento ao infrator $^{286}$. Se o sofrimento puder ser concentrado apenas na pena, e não na duração do processo, diminui-se a desproporcionalidade do castigo. No âmbito da relação profissional, além do abalo psicológico, a demora na instauração ou na conclusão do processo administrativo pode ensejar situação de pressão ou acarretar, ainda, o cometimento de outros ilícitos ou favores.

Portanto, nem mesmo um sistema normativo elaborado de forma perfeita logrará atingir a eficiência do poder punitivo sem que esteja integrado com um excelente sistema institucional de aplicação de pena.

\footnotetext{
${ }^{283}$ Nesse sentido: ARAÚJO, Edmir Netto de. O ilícito administrativo e o seu processo, cit., p. 152.

${ }^{284}$ SILVA SÁNCHES, Jesús-María. Eficiência e direito penal. Trad. Maurício Antonio Lopes. Barueri: Manole, 2004. p. 40. (Estudos de direito penal; v. 11).

${ }^{285}$ BECCARIA, Cesare Bonesana. op. cit., p. 77.

${ }^{286}$ MACEDO, Pedro de Sousa. Poder disciplinar patronal. Coimbra: Livr. Almedina, 1990. p. 169.
} 
O lamentável é que, como lembra Fabio Medina Osório no curso de toda a sua obra, as causas da crise de qualidade e eficiência do sistema punitivo, tanto penal quanto administrativo, se relacionam com a precária gestão das instituições controladoras, entre elas, as práticas patrimonialistas e clientelistas na provisão dos postos de confiança em todos os escalões da Administração Pública e a ausência de profissionais técnicos em cargos de coordenação ou de decisão, que impedem o desenvolvimento de um boa gestão e da eficiência funcional em toda a máquina administrativa e que também acabam contaminando o sistema punitivo ${ }^{287}$.

Vê-se, portanto, que o poder disciplinar é mais um dos aspectos a ser considerado para o perfeito funcionamento da administração pública, pois sua existência colabora para o alcance de uma atividade administrativa eficiente. Para que sua contribuição seja efetiva, concretizada, materializada, deve atuar, por si só, de forma eficiente, tanto em termos normativos, como em termos de aplicação. Sua aplicação não pode sofrer deformação, devendo ocorrer de acordo com os legítimos interesses, de forma consciente e desapaixonada para que não atue no sentido oposto, isto é, para que não degrade o ambiente funcional $^{288}$.

\subsubsection{Poder disciplinar como fator de estímulo aos funcionários públicos}

O afastamento da pessoa de comportamento viciado é a finalidade das penas de demissão, que são aplicadas a comportamentos graves na intensidade e na profundidade, comportamentos incompatíveis e inconvenientes ao serviço público e que demonstram vícios de personalidade que não admitem correção ou tolerância.

Diz-se que, neste caso, a pena visa não o castigo, mas a limpeza da organização, que é meio de contribuir ao seu bom funcionamento ${ }^{289}$. Protege-se a Administração Pública, recompondo sua ordem, impedindo, ainda, eventual desprestígio de sua imagem, caso nenhuma providência fosse tomada com relação ao infrator.

Mesmo nesse caso, concordamos com aqueles que entendem que o afastamento da pessoa do exercício do cargo público não pode ser definitivo, diante da impossibilidade de

\footnotetext{
${ }^{287}$ OSÓRIO, Fábio Medina. Direito administrativo sancionador, cit., p.45-6, 53 e 376.

${ }^{288}$ Nesse sentido: COSTA, José Armando da. op. cit., p. 28 e 48.

${ }^{289}$ Conforme HUERGO LORA, Alejandro. Las sanciones administrativas. Madrid: Iustel, 2007. p. 181.
} 
penas de caráter perpétuo (artigo $5^{\circ}$, XLVII, $b$, da Constituição Federal) ${ }^{290}$. Izaías Dantas Freitas escreve:

As penalidades repressivas deverão ser destinadas apenas para aqueles servidores totalmente desqualificados para atuar em alguma função pública, sendo importante, contudo, que haja uma reavaliação daquelas penas que vedam em definitivo o reingresso de servidores no funcionalismo público, no sentido de lhes permitir o acesso a cargos de natureza inferior, mantida a impossibilidade de acesso para cargos de direção. $^{291}$

Assim, neste caso de possibilidade de retorno do funcionário aos quadros administrativos pode-se considerar que a anterior pena de demissão pode ter atuado de forma reeducativa ${ }^{292}$, isto é, pode ter agido como fator de estímulo tanto dos funcionários públicos que viram que houve punição do infrator, quanto do próprio infrator que foi retirado dos quadros, tendo se recuperado e novamente ingressado no serviço público, mediante um novo processo de seleção.

Por meio da finalidade reeducativa, também denominada pedagógica e corretiva, o funcionário aperfeiçoa seu comportamento e melhora, evitando-se, inclusive, perda de tempo e energia com futuros processos administrativos.

As penas pedagógicas "corrigem fazendo sentir ao autor do facto punido a incorrecção do seu procedimento e a necessidade de melhorar a sua conduta", chamam a atenção do agente para o cumprimento dos deveres, advertindo-o da incidência em falta disciplinar ${ }^{293}$, e visam estimulá-lo a cumprir melhor os seus deveres ou a ter mais cuidado no cumprimento deles ${ }^{294}$.

Nesse sentido, ao que parece, são esses tipos de penas que melhor atendem ao dever de eficiência da Administração Pública, pois proporcionam melhoria na atuação estatal, devendo ser incentivadas mediante algumas diretrizes a serem tomadas pela Administração Pública.

\footnotetext{
${ }^{290}$ Nobre Junior defende que há impossibilidade de se aplicar ao ímprobo a impossibilidade de retornar ao serviço público após a perda do cargo, diante da impossibilidade de penas de caráter perpétuo (artigo $5^{\circ}$, XLVII, $b$, da Constituição Federal). Menciona, nesse sentido, acórdão proferido no STF, RE 154.134/SP, DJ 28/10/1999, p. 17. (NOBRE JUNIOR, Edilson Pereira. Improbidade administrativa: alguns aspectos controvertidos. Revista de Direito Administrativo, Rio de Janeiro, n. 235, p. 61-91, jan./mar. 2004).

${ }^{291}$ FREITAS, Izaías Dantas. op. cit., p. 618-625.

${ }^{292}$ Conforme FREITAS, Izaías Dantas. op. cit., p. 618-625.

${ }^{293}$ BARROS JÚNIOR, Carlos S. de. op. cit., p. 119.

${ }^{294}$ CAETANO, Marcello. Princípios fundamentais do direito administrativo. Reimpressão da edição Brasileira de 1977, 2. reimpr. Portuguesa. Lisboa: Livr. Almedina, 2003. p. 316-317.
} 
O sentido amplo de poder disciplinar não é dotado de conteúdo somente sancionatório, reprimindo os comportamentos contrários aos interesses do grupo, apesar de este ser seu conteúdo nuclear, mas abrange também um enfoque ordenador e preventivo, definindo regras e orientando o grupo à sua submissão ${ }^{295}$.

Desnecessário fundamentar que o ideal para a ordem disciplinar é que a sanção funcione predominantemente no seu sentido preventivo, pois esta é a forma mais eficiente e conveniente de se preservar a normalidade do Serviço Público. No seu atuar repressivo, a sanção, por mais criteriosa e judiciosa que seja a sua imposição, sempre deixa resquícios negativos em detrimento da repartição. O prevenir sempre esteve, sob todos os ângulos, em nível bem superior ao reprimir, remediar. ${ }^{296}$

Assim, seria interessante despojar as inspeções e correições do seu usual caráter sancionatório e convertê-las transmissoras das diretrizes adotadas pelas instâncias decisórias e orientar em relação às deficiências e desajustes que observem; isso motivaria a busca pela melhora no desempenho das atividades pelo funcionário ${ }^{297}$. Assim, ao invés de detectar a falta e impor sanções, o ideal seria detectar a falta para propor soluções ${ }^{298}$. Afinal, "a existência de mecanismos de controle tem uma eficácia profilática, evitando transgressões" 299 , lembrando-se, ainda, que o conhecimento prévio das regras e dos comportamentos esperados pela Administração Pública tranquiliza o agente que passa a ter maior segurança na realização de suas atividades.

Fábio Medina Osório observa que a educação e as medidas preventivas são o melhor caminho para se evitar ilícitos, embora não se possa olvidar o importante sentido pedagógico que possuem as sanções impostas, tanto para a pessoa do agente como a título de um interessante exemplo à comunidade. No entanto, a sanção deveria ser reservada como última ratio do Estado, quer dizer, deveria ser respeitado, também na punição administrativa, o princípio da subsidiariedade do direito sancionador, a fim de se evitar a banalização das sanções e do próprio direito administrativo sancionador, já que existem

\footnotetext{
${ }^{295}$ RAMALHO, Maria do Rosário Palma. Do fundamento do poder disciplinar laboral. Coimbra: Livr. Almedina, 1993. p. 117.

${ }^{296}$ COSTA, José Armando da. op. cit., p. 242.

${ }^{297}$ MARTÍN-RETORTILLO Y BAQUER. Sebastián. El reto de una administración racionalizada, cit., p. 90.

${ }^{298}$ FERRAZ, tratando do Tribunal de Contas, mas utilizando pensamento que se aplica ao caso em questão. (FERRAZ, Luciano. Tribunal de Contas - controle de serviço concedido. III seminário de direito administrativo controle das políticas públicas proteção do usuário. Controle pelos Tribunais de Contas da eficiência e eficácia dos serviços concedidos. Revista de Direito Administrativo, Rio de Janeiro, n. 239, p. 439-455. jan./mar. 2005).

${ }^{299}$ DALLARI, Adilson Abreu. Administração pública no estado de direito, cit., p. 33-41. 1994.
} 
outros meios mais eficazes e menos drásticos para fazer valer os comandos legais ${ }^{300}$.

Pertinente é a observação feita por Maria José Falcón y Tella a respeito do tema; embora se referindo ao direito penal, a observação também se aplica ao campo ora estudado:

\begin{abstract}
Alguns poderiam dizer, e em determinadas situações é certo, que a dor faz o homem crescer, que lhe aproxima ao transcendente, que lhe faz mais maduro, que lhe faz nascer de novo e ter uma percepção mais profunda da realidade. Alguns de nós talvez já experimentamos estes benefícios. Mas também experimentamos o contrário: a dor que paralisa, a dor que cria amargura, que atrasa o crescimento interior, que deteriora.

Uma das regras seria então: na dúvida, não se deve impor a dor ou, pelo menos, há que impor o mínimo de dor possível. Isso é aplicável ao castigo. Busquemos opções aos castigos, não somente castigos opcionais. A aflição é inevitável, mas não é o inferno criado pelos homens. ${ }^{301}$
\end{abstract}

A ação disciplinar pode ocorrer de forma positiva, isto é, com encorajamento, recompensas, elogios, treinamentos ou orientações, estando elas, inclusive, abrangidas pelo regime disciplinar ${ }^{302}$. Não é à toa que é prevista constitucionalmente a instituição de adicional ou prêmio de produtividade (artigo 39, $\S 7^{\circ}$ da Constituição Federal).

Nesse sentido, caberia à Administração Pública dar efetividade ao contido no artigo 39 caput da Constituição Federal e desenvolver políticas administrativas que visem incentivar posturas construtivas, não apenas condenando as condutas proibidas, mas principalmente premiando aquelas que se mostrem positivas ${ }^{303}$, ainda que o resultado final não tenha logrado alcançar o intento almejado.

A finalidade corretiva da pena muito bem contribui para o alcance da eficiência de todo o sistema, já que se adequa às sutilezas das relações de trabalho e visa, sobretudo, redirecionar a atividade do funcionário infrator para que melhor se adapte aos objetivos institucionais. Mantém-se tal funcionário no sistema, que já está inserido em seu campo de atuação e possui conhecimento e experiência naquilo que desenvolve, aprimorando a sua atuação, ao invés de dispensá-lo, surgindo a necessidade de nova contratação, reiniciandose todo o processo de adaptação do novo funcionário.

\footnotetext{
${ }^{300}$ OSÓRIO, Fábio Medina. Direito administrativo sancionador, cit., p. 547.

${ }^{301}$ FALCÓN Y TELLA, María José; FALCÓN Y TELLA, Fernando. Fundamento e finalidade da sanção: existe um direito de castigar?, cit., p. 54.

${ }^{302}$ COSTA, José Armando da. op. cit., p. 12.

${ }^{303}$ São as denominadas sanções premiais, as quais visam o encorajamento de um ato e não o desencorajamento de outro (sanção-castigo). (FERRAZ JUNIOR, Tercio Sampaio. Introdução ao estudo do direito: técnica, decisão dominação. São Paulo: Atlas, 1988. p. 116).
} 
A finalidade corretiva não exclui a presença das demais, mas quando ressaltada, em determinados casos, faz a sanção escolhida surtir efeitos mais positivos na esfera individual do agente público do que os demais tipos de sanção.

Não é difícil perceber que o atual sistema punitivo brasileiro, como um todo, é carente de políticas destinadas à correção e ressocialização do infrator. É o que se depreende dos estudos doutrinários a respeito do tema, no âmbito criminal, que também se aplicam ao poder disciplinar, e a ausência de estudos no campo do direito administrativo disciplinar.

Isso não impede, entretanto, que tal finalidade seja valorada pelo administrador ao impor uma pena que melhor atenda ao objetivo final do poder disciplinar, que é a eficiência na atuação administrativa como um todo, inclusive do próprio sistema disciplinar.

O objetivo do poder disciplinar deve ser orientar, estimular, corrigir e, apenas após esgotadas essas etapas, punir os incorrigíveis. Deve-se diminuir o foco na responsabilidade e aumentar o foco no controle. Assim, é possível estabelecer uma forma de disciplina positiva, pela qual a punição imediata é substituída por sessões de aconselhamentos ${ }^{304}$, por exemplo, ou aplicada de forma progressiva, como a que sugere Idalberto Chiavenato, pela qual seriam feitas "intervenções progressivas e paulatinas que dão ao funcionário a oportunidade de corrigir seu comportamento antes que seja desligado da organização"305.

A eficiência, portanto, se obtém de forma global, decorre da organização, da estrutura, da coordenação e da aplicação do sistema disciplinar com a priorização de outras soluções que não a sanção. Nunca será conseguida de forma individualizada ou com a utilização de apenas um instituto. Assim, o poder disciplinar pode e deve ser utilizado na contínua busca pelo ideal de eficiência.

\footnotetext{
${ }^{304}$ CHIAVENATO, Idalberto. Gestão de pessoas: e o novo papel dos recursos humanos nas organizações. 2. ed. totalmente rev. e atual. 5. reimpr. Rio de Janeiro: Elsevier, 2004. p. 412.

${ }^{305}$ Id. Ibid., p. 410.
} 


\subsection{Responsabilidade administrativa por ineficiência no ordenamento jurídico pátrio}

\subsubsection{Na Constituição Federal}

\subsubsection{Estágio probatório}

A estabilidade é o regime aplicável àqueles que se sujeitam ao regime estatutário e que possuem cargos efetivos. Por força do contido no artigo 19 das Disposições Transitórias, se aplica também aos servidores civis da Administração Direta, autarquia e fundações públicas da União, Estados, Distrito Federal e Municípios que, embora não tivessem sido nomeados por concurso, estavam em exercício há, pelo menos, cinco anos na data da promulgação da Constituição Federal, excluindo-se, entretanto, os professores universitários, os ocupantes de cargos, funções e empregos de confiança ou em comissão, além dos que a lei declara de livre exoneração.

Trata-se de garantia destinada às pessoas que exercem cargos de atribuições relevantes ou exclusivas de Estado, das quais avultam interesses públicos básicos, que necessitam de uma atuação imparcial por parte do agente público, como mencionado na introdução.

Para se conquistar tal estabilidade, entretanto, é necessário que o funcionário público passe pelo estágio probatório, período de tempo previsto na Constituição Federal, no qual deve haver avaliação especial de desempenho por comissão instituída para essa finalidade (artigo 41, § $4^{\circ}$ ).

Embora se saiba que em referido instituto o que prevalece é a preocupação institucional, e não o interesse profissional ${ }^{306}$, não se pode negar que a exoneração no estágio probatório tem repercussão na vida e na ficha do indivíduo, podendo inviabilizar, por exemplo, seu ingresso em outro concurso, podendo ter as mesmas consequências reais que uma verdadeira punição. Lembramos que sanção disciplinar deve atingir o indivíduo

\footnotetext{
${ }^{306}$ Conforme VERZOLA, Maysa Abrahão Tavares. A sanção no direito administrativo brasileiro. 2008. Dissertação (Mestrado) - Faculdade de Direito, Universidade de São Paulo, São Paulo, 2008. p. 29.
} 
não na sua qualidade de homem ou cidadão, mas somente na sua especial qualidade de sujeito da relação especial entre as partes ${ }^{307}$.

Assim, imputar ao agente uma conduta ou postura que o desqualifique a ponto de ser excluído do serviço público reflete em sua esfera individual, implicando em uma evidente desvalia. Por tal motivo, é imprescindível que seja observado o procedimento que prestigie o contido no artigo $5^{\circ}, \mathrm{LV}$ da Constituição Federal $^{308}$ e respeitado os princípios da legalidade ${ }^{309}$, do devido processo legal ${ }^{310}$ entre outros.

Trata, a jurisprudência, da seguinte forma sobre a não aprovação do funcionário no estágio probatório:

Deve basear-se em motivos e fatos reais que revelem inaptidão ou desídia do funcionário em observação, defeitos esses apuráveis e comprováveis pelos meios administrativos consentâneos (ficha de ponto, anotações na folha de serviço, investigações regulares sobre a conduta do trabalho etc.), (...) $\mathrm{O}$ necessário é que a Administração justifique, com base em fatos reais, a exoneração. ${ }^{311}$

Analisando-se os acórdãos sobre o assunto, percebe-se que, embora o próprio Superior Tribunal de Justiça tenha afirmado que a exoneração no estágio probatório pressupõe "sempre a inexistência de infração, pois se baseia exclusivamente na conveniência da dispensa", sem qualquer caráter punitivo ${ }^{312}$, os motivos que ensejaram a exoneração, em cada um dos casos julgados, basearam-se em fatos objetivos que ensejariam, inclusive, a demissão do funcionário, isto é, todos se baseiam em alguma infração. São casos de homicídio, embriaguez no exercício das funções, fatos que atentam contra a moral e os bons costumes, apropriação de dinheiro público, conduta reiterada e incompatível com o exercício das funções e outros fatos graves que depõem contra a permanência do funcionário nos quadros públicos, ainda que já fosse estável ${ }^{313}$.

\footnotetext{
${ }^{307}$ ALESSI, Renato. Sistema istituzionale del diritto amministrativo italiano, cit., p. 211.

${ }^{308}$ Marques Neto ressalta que a proteção conferia pelo artigo $5^{\circ}$, LV da Constituição Federal, se dirige aos acusados em geral, se referindo a "qualquer um a quem seja imputada uma conduta potencialmente passível de acarretar punição, sanção, responsabilização. (...) A partir do momento em que há uma atribuição subjetiva, potencial até, de eventual falta, surge a contraposição de interesse uma vez que o imputado (acusado) certamente não haverá de concordar com que se lhe inculque culpa". (MARQUES NETO, Floriano de Azevedo. Processo administrativo inquisitorial: eficiência investigativa e garantias constitucionais. Revista de Informação Legislativa, Brasília, v. 42, n. 167, p. 191-211, jul./set. 2005).

${ }^{309}$ RE 43.363/RS. Ministro Hahnemann Guimarães, DJ 2.8.1962, p. 2039.

${ }^{310}$ RE 5.1238/SC, Ministro Victor Nunes, DJ 8.8.1963.

${ }^{311}$ RMS 859/RJ, Ministro José Jesus Filho, DJ 17/2/1992, p. 1364.

${ }^{312}$ RMS 859/RJ, Ministro José Jesus Filho, DJ 17/2/1992, p. 1364.

${ }^{313}$ RMS 18205/SP, Ministro Felix Fischer, DJ 20/3/2006, p. 306; RMS 859/RJ, Ministro José Jesus Filho, DJ 17/2/1992, p. 1364; RMS 10993/SP, MinistroVicente Leal, DJ 15/5/2000, p. 204; RMS 6675/MG, Ministro
} 
Vê-se, portanto, pelas decisões judiciais, que, ao que parece, há uma subutilização do instituto do estágio probatório, já que a exoneração ocorre somente em hipóteses em que caberia a demissão.

Sua previsão, entretanto, permitiria afastar do exercício da função aquele que, evidentemente, não se adequou a ela, avaliando-se aptidão, disciplina, retidão moral, assiduidade, responsabilidade, dedicação e eficiência ${ }^{314}$. Assim, seria possível, por exemplo, não se confirmar na carreira o motorista que tem medo de dirigir ou uma pessoa grosseira ou temperamental, cuja função essencial é o atendimento público, ou um funcionário que simplesmente não se revela capaz de executar a função que lhe fora atribuída.

Regra com finalidade semelhante existe no direito do trabalho com relação ao menor aprendiz, que, segundo o artigo 433, I da Consolidação das Leis do Trabalho, pode ter seu contrato extinto em razão de seu desempenho insuficiente ou por sua inaptidão. Trata-se de perda do vínculo no qual não é necessária a existência de culpa para se caracterizar.

Tal instituto não é novidade no ordenamento, estando previsto desde o Decreto-Lei $\mathrm{n}^{\circ} 1.713$, de 28 de outubro de 1939, e a Lei $\mathrm{n}^{\circ} 1.711$ de 28 de outubro de 1952, antigos Estatutos dos Funcionários Públicos Civis da União. Tais normas já previam um período de avaliação, no qual se analisaria, entre outros requisitos, a eficiência.

A avaliação final por comissão instituída é bastante importante, na medida em que evita a apreciação pelo superior hierárquico imediato que, em razão da relação cotidiana, pode desenvolver os mais diversos sentimentos com relação ao avaliado, prejudicando a avaliação imparcial.

É preciso mencionar a importância de tal avaliação periódica ser disponibilizada ao servidor avaliado, assim que efetuada, que, apesar de estar sendo observado em todos os aspectos de sua personalidade, deve ter a oportunidade de adequá-los à exigência da Administração Pública ou, até mesmo, questionar a parcialidade ou algum outro vício de caráter objetivo ou subjetivo durante sua avaliação.

Vicente Leal, DJ 1/9/1997, p. 40888; RMS 5306/ES, Ministro Vicente Leal, DJ 4/11/1996, p. 42526; RMS 15324/MS, Ministro Paulo Gallotti, DJ 17/9/2007, p. 356; RMS 1.912-3/MG, Ministro Jesus Costa Lima, DJ 14/11/1994, p. 30.962.

${ }^{314}$ MODESTO, Paulo. Estágio probatório: questões controversas. Revista Eletrônica de Direito do Estado (REDE), Salvador, n. 10, abr./jun. 2007. Disponível em: <www.direitodoestado.com.br/rede/asp>. Acesso em: 13 nov. 2009. 
Deve haver, ainda, concomitantemente com a avaliação e durante o período do estágio, cursos de adaptação, treinamento e aperfeiçoamento daquele que está ingressando no serviço, para que, desde cedo, conduza seu comportamento no caminho esperado pela Administração Pública. Marçal Justen Filho sugere uma avaliação permanente e continuada da aptidão e da capacidade do sujeito, a ser acompanhada de forma permanente por servidores especificamente encarregados dessa atribuição e, ainda, com procedimento composto por etapas nas quais as responsabilidades seriam atribuídas de forma crescente ${ }^{315}$.

Ressalte-se, também, que alguns atos incorretamente praticados nesse período haverão de ser analisados de acordo com o contexto do momento e com a inexperiência da pessoa $^{316}$.

Esse é o verdadeiro sentido do estágio probatório, importante instrumento para o alcance da eficiência dos agentes públicos.

\subsubsection{Avaliação periódica de desempenho}

A fim de que o direito à estabilidade não exceda em seus resultados e cumpra o propósito a que foi criado, o artigo 41 da Constituição Federal, a partir da Emenda Constitucional $n^{\circ} 19 / 98$, embora com algumas críticas ${ }^{317}$, passou a prever que os servidores estáveis poderão perder seus cargos, entre outros, mediante procedimento administrativo de avaliação periódica de desempenho, na forma da lei complementar, assegurada a ampla defesa.

Segundo Elival da Silva Ramos:

O que se quis foi evitar a acomodação que a aquisição da estabilidade por vezes enseja, com a perda de interesse no aperfeiçoamento funcional, o que, em uma quadra de veloz transformação das técnicas laborais, pode redundar em inaptidão do funcionário para realização das tarefas inerentes ao seu cargo, sob o signo do princípio da eficiência, agora expressamente arrolado no caput do art. 37 da Lei Maior. ${ }^{318}$

\footnotetext{
${ }^{315}$ JUSTEN FILHO, Marçal. Curso de direito administrativo, cit., p. 771-772.

${ }^{316} \mathrm{Em}$ acórdão, o STJ considerou que, entre outros, o fato de a servidora se encontrar em estágio probatório à época em que praticou determinado ato considerado ineficiente, conduziria à necessidade de aplicação de penalidade menos gravosa do que aquela aplicada pela Administração Pública. (STJ, MS n ${ }^{\circ}$ 10.220/DF, Ministro Arnaldo Lima, DJU 13.8.2007).

${ }^{317}$ Conforme LIMA, Ruy Cirne. Princípios de direito administrativo. 7. ed. rev. e reelaborada por Paulo Alberto Pasqualini. São Paulo: Malheiros Ed., 2007.p. 173 e 456.

${ }^{318}$ RAMOS, Elival da Silva. A proteção aos direitos adquiridos no direito constitucional brasileiro, cit., p. 255-256.
} 
Tal hipótese não se confunde com a infração de ineficiência, pois não implica a prática de ilícito disciplinar, "pois seu objetivo é avaliar periodicamente, por critérios técnicos e teoricamente objetivos, as condições de aptidão e o desempenho do servidor público em relação ao cargo para o qual foi admitido"319.

A perda do cargo, neste caso, deve ser a última alternativa, justificando-se apenas nos casos em que há causa para tanto, conforme o disposto no artigo $4^{\circ}$ da Convenção $\mathrm{n}^{\circ}$ 158, de 1982, da Organização Internacional do Trabalho: "Não se porá fim à relação de trabalho, a menos que exista uma causa justificada relacionada com a capacidade ou conduta do trabalhador ou baseada nas necessidades de funcionamento da empresa" ${ }^{\text {}} 20$.

A incapacidade profissional é deduzida, em regra, por meio de fatos sucessivos, podendo ser apurado somente por meio de contínuas e variadas formas ${ }^{321}$, que demonstrem que o agente que não é hábil a exercer as funções para as quais foi contratado. Para se realizar tal apreciação, é necessário analisar a atuação e o comportamento da pessoa em confronto com os de seus colegas que exercem as mesmas funções. Se houver constatação de atuação deficiente por parte dele, deverá haver exoneração.

Quando houver constatação da ineficiência contumaz, será possível se estender a responsabilidade, alcançando-se o superior ou o agente que inseriu, escolheu ou manteve o agente ineficiente em função incompatível com as suas limitações ou que deixou de observar a reiteração no comportamento indevido.

Concordamos com Alejandro Uergo Lora que, analisando instituto semelhante na Espanha, afirma que, por não se tratar de hipótese de sanção, não se deve aplicar o princípio da culpabilidade, entre outras coisas porque se chegaria ao absurdo de que os funcionários mais inúteis seriam os mais difíceis de se remover, porque se são ineficientes não é por culpa deles, mas porque não podem atuar de outra forma. Ademais, o princípio da culpabilidade se fundaria no fato de que a sanção persegue o castigo do infrator, sua retribuição, sem que dela dependa diretamente a tutela de um determinado interesse público ou de terceiros. Assim, quando é o interesse público ou de terceiros o que se tutela diretamente, o princípio da culpabilidade poderia ser afastado ${ }^{322}$. No caso, o que se visa

\footnotetext{
${ }^{319}$ ARAÚJO, Edmir Netto. Curso de direito administrativo, cit., p. 306.

${ }^{320}$ Ver NASCIMENTO, Amauri Mascaro. Curso de direito do trabalho: história e teoria geral do direito do trabalho: relações individuais e coletivas do trabalho. São Paulo: Saraiva, 2007. p. 790.

${ }^{321}$ Nesse sentido: CAETANO, Marcelo. Do poder disciplinar no direito administrativo português, cit., p. 67.

${ }^{322}$ HUERGO LORA, Alejandro. op. cit., p. 318 e 380.
} 
proteger diretamente é o bom funcionamento do serviço ${ }^{323}$ e, sendo assim, o elemento culpa pode, de fato, ser afastado, para que haja punição.

A desnecessidade de culpa também se comprova ao se observar que, no projeto da reforma tratada neste trabalho, havia sido previsto o direito à indenização (meio salário por ano trabalhado), na hipótese de demissão por insuficiência de desempenho ${ }^{324}$. Se fosse cogitada a necessidade de culpa do agente, a indenização jamais teria sido sugerida.

Vale lembrar que tal hipótese de afastamento do funcionário público está condicionada à existência de lei complementar que ainda não existe e que, na hipótese de o servidor ser considerado insatisfatório, ele se sujeitará à exoneração, e não demissão, pois não tem natureza punitiva ${ }^{325}$.

Lembre-se, ainda, que o vínculo profissional que existe entre o servidor e o Estado é característica que integra a personalidade da pessoa, sendo certo que a sua extinção apenas pode ocorrer nas situações e na forma minuciosamente delineadas no ordenamento jurídico, conforme já mencionado. No caso, é obvio que há um prejuízo para o agente, ainda que não haja propriamente uma sanção, de forma que tal exoneração não pode ser arbitrária nem imotivada.

Neste sentido, a concepção reducionista do legislador e do aplicador nessa matéria, sobretudo na disciplinar, no sentido de dar a suas consequências importância reduzida, implica em doença enquadrável como vulnerações da segurança ou da certeza do direito ${ }^{326}$.

Sabe-se que o princípio do devido processo legal, que compreende o contraditório e a ampla defesa ${ }^{327}$, possui sentido material e é aplicado em todas as relações jurídicas, inclusive as de direito privado $^{328}$, de forma que nunca poderá ser afastado, mormente

\footnotetext{
${ }^{323}$ Conforme OLIVEIRA, Régis Fernandes de. Servidores públicos. 2. ed. São Paulo: Malheiros Ed., 2008. p. 40.

${ }^{324}$ PEREIRA, Luiz Carlos Bresser. Crise econômica e reforma do Estado no Brasil: para uma nova interpretação da América Latina, cit., p. 288.

${ }^{325}$ Nesse sentido: MELLO, Celso Antônio Bandeira de. Curso de direito administrativo, cit., p. 303 e Id. Apontamentos sobre os agentes e órgãos públicos, cit., p. 39.

${ }^{326}$ Conforme MARTINS, Eliezer Pereira. Segurança jurídica e certeza do direito em matéria disciplinar aspectos atuais. Revista de Direito Administrativo, Rio de Janeiro, n. 230, p. 141-152, out./dez. 2002.

${ }^{327}$ STF, Recurso Extraordinário no ${ }^{\circ}$ 170.463/DF, Ministro Marco Aurélio; STJ, Recurso em Habeas Corpus $\mathrm{n}^{\circ}$ 7.418/MS, Ministro Vicente Leal; STJ, Recurso Especial $\mathrm{n}^{\circ}$ 159.148/RJ, Ministro Luiz Vicente Cernicchiaro; TRF4, AMS 94.04.51732-1/RS, DJU 21.10.1998, p. 814, Desembargador Joel Ilan Paciornik; TJSP, AC 163.888-1/5, Desembargador Fonseca Tavares.

${ }^{328}$ TJPR, AC 39.811-8, Desembargador Ulysses Lopes.
} 
quando se discute relações que podem culminar com sanções ${ }^{329}$ ou qualquer outro prejuízo ao interessado.

Não há como se afastar, portanto, a observância do devido processo legal com todas as suas implicações, principalmente relacionadas ao direito de defesa quando há contrariedade de interesses, pois as garantias individuais estão sempre acima da eficácia da aplicação das sanções administrativas em geral $^{330}$.

Assim é que entendemos que, independentemente do nome que se dê ao procedimento adotado para a apuração da conduta ineficiente do servidor e da função que ele exerça, não pode haver a perda do cargo sem o devido respeito aos princípios procedimentais do ordenamento jurídico, o que acaba por igualar, na prática, o procedimento avaliatório e o processo administrativo mencionados nos artigos 247, parágrafo único e $41, \S 1^{\circ}$, III da Constituição Federal.

Não é possível, portanto, estabelecer distinção entre os procedimentos aludidos em tais normas, mas sim notar o intuito da Constituição Federal de deixar claro a necessidade do processo administrativo com todas as suas garantias tanto na hipótese de perda do cargo por insuficiência de desempenho pelos funcionários públicos em geral, como também e principalmente por aqueles que exercem atividades exclusivas de Estado, e não apenas para estes últimos.

Veja-se que o projeto de Lei-Complementar $n^{\circ} 248-\mathrm{D}$, de 1998, que disciplina a perda de cargo por insuficiência de desempenho do servidor público estável, dispõe que o respectivo processo administrativo deve observar o contraditório e a ampla defesa (artigo 11). Em relação aos que desenvolvem atividades exclusivas de Estado, verifica-se que o processo administrativo é o mesmo. A única diferença é que, para eles, é previsto recurso hierárquico especial com efeito suspensivo para a autoridade máxima do órgão ou entidade a que estiver vinculado, desde que a competência originária para o ato de demissão for atribuída à autoridade hierarquicamente inferior àquela para a qual o recurso for destinado (artigo 16), o que confirma nossa conclusão de que, na essência, os procedimentos não são e nem devem ser diferentes.

\footnotetext{
${ }^{329}$ STJ, MS 645/DF, DJ 1.7.1991, Ministro Vicente Cernicchiaro; STJ, Recurso Ordinário em Mandado de Segurança n ${ }^{\circ}$ 9.501/PB, Ministro Edson Vidigal; TRF1, AMS 00873-9/DF, DJ 29.6.1990, Desembargador Eustáquio Silveira.

${ }^{330}$ MARQUES NETO, Floriano de Azevedo. op. cit., p. 191-211.
} 
A avaliação de desempenho é um importante instituto a ser utilizado para analisar qual a contribuição do profissional para o perfeito funcionamento da organização, resolver problemas de desempenho, melhorar a qualidade do trabalho e a qualidade de vida dentro das organizações ${ }^{331}$. Atente-se ao fato de que todo profissional espera um retorno sobre seu desempenho, sem o qual o mesmo caminha às cegas, sem correções ou reconhecimentos, e sem, ainda, o exercício de suas potencialidades, podendo a avaliação de desempenho ser utilizada também nesse sentido, quer dizer, como forma de reconhecer e motivar o funcionário ${ }^{332}$.

\subsubsection{Na legislação federal}

O Estatuto vigente para os servidores civis da União, Lei $\mathrm{n}^{\circ} 8.112$, de 11 de dezembro de 1990, a exemplo do que ocorre naqueles que pertencem aos demais entes federativos, disciplina deveres e proibições funcionais, que constituem o regime disciplinar do funcionário público.

Todos os deveres e proibições possuem a finalidade de disciplinar a conduta e a atuação do funcionário que culminem com o bom desempenho da atividade pública e a sua consequente entrega final para a população de forma satisfatória. Por isso é que se ligam, de certa forma, com a eficiência administrativa, pois é essa a finalidade buscada na prescrição das infrações. Afinal, não se pode ser um bom administrador desrespeitando qualquer dever imposto pelo ordenamento ${ }^{333}$.

Não é preciso analisar de forma individualizada os deveres e as infrações constantes da legislação; basta verificar que são condutas esperadas em qualquer ambiente profissional para não desestabilizar a atuação individual ou do grupo que desempenha determinada

\footnotetext{
${ }^{331}$ CHIAVENATO, Idalberto. Gestão de pessoas: e o novo papel dos recursos humanos nas organizações, cit., p. 223.

${ }^{332}$ Conforme REALE JÚNIOR, Miguel. Reforma administrativa e governabilidade. Colab. Paulo Rabello de Castro, Cláudia Maria Costin, Pedro Luiz Barros Silva. Extraído da mesa redonda sobre o tema "reforma administrativa e governabilidade", organizada pela Fundação Konrad-Adenauer-Stiftung na sede do Parlamento Latino-Americano, no dia 24 de abril de 1995. São Paulo: Fundação Konrad-AdenauerStiftung, 1995. p. 39.

${ }^{333}$ FALZONE, Guido. Il dovere di buona amministrazione: parte I, cit., p. 86 e 113, rodapé 12.
} 
função, bem como coordenar a união de esforços para a consecução da finalidade pública $^{334}$.

Apesar de todos os deveres e proibições estabelecidos em tal lei terem como finalidades mediata ou imediata a garantia do bom andamento do serviço, ao contrário do que previa o antigo Estatuto dos Funcionários Civis da União, Decreto-Lei no 1.713, de 28 de outubro de 1939, e o Decreto-Lei $\mathrm{n}^{\circ}$ 200, de 25 de fevereiro de 1967, o atual Estatuto Federal não prevê de forma explícita a demissão do servidor efetivo ou estável comprovadamente ineficiente.

No texto atual, a desídia (artigo 117, XV) é o comportamento que mais se aproxima da ineficiência. No entanto, não é punível diretamente com demissão ${ }^{335}$. A desídia seria o contraposto da previsão contida no artigo 116, I, que prevê como dever "exercer com zelo e dedicação as atribuições do cargo".

O dever de zelo, segundo José Cretella Junior, nada mais é que o dever de diligência ou o dever de aplicação que coincidem com o "escrúpulo no cumprimento dos deveres, atenção no exercício das funções, cuidado especial ao resolver inúmeros problemas”, tratar do exercício de suas funções como se tratasse de seus próprios negócios, com a atenção do clássico bonus paterfamilias ${ }^{336}$.

O significado da desídia é preguiça, má vontade e indolência ${ }^{337}$, compreende uma falta de diligência no cumprimento das atribuições, sendo necessário o elemento culpa.

Nas palavras de Edmir Netto de Araújo, a desídia assume "um sem-número de formas, sempre durante o serviço, violando aquele dever de lealdade, diligência e interesse que o empregado deve ter em relação ao seu serviço e ao seu empregador”. Para ele, a desídia é a negligência, desleixo, descaso, relaxo, incúria do empregado no exercício das funções e no desempenho dos encargos que lhe competem ${ }^{338}$, que nada mais é que um dos aspectos da ineficiência.

Mauricio Godinho Delgado resume o instituto da seguinte forma, a qual aderimos:

\footnotetext{
${ }^{334}$ Para Falzone, os todos os deveres dos funcionários estão englobados no dever de diligência. (FALZONE, Guido. op. cit., p. 112-113, rodapé 12).

${ }^{335}$ STF, RMS 24699/DF, Ministro Carlos Ayres Britto, DJ 1/7/2005, p. 56.

${ }^{336}$ CRETELLA JÚNIOR, José. Curso de direito administrativo. 17. ed. rev. e atual. Rio de Janeiro: Forense, 2000. p. 511.

${ }^{337}$ COSTIN, Cláudia Maria. Reforma administrativa e governabilidade. Colab. Paulo Rabello de Castro, Pedro Luiz Barros Silva, Miguel Reale Júnior, cit., p. 69.

${ }^{338}$ ARAÚJO, Edmir Netto. Curso de direito administrativo, cit., p. 420 e 958.
} 
Trata-se de tipo jurídico que remete à idéia de trabalhador negligente, relapso, culposamente improdutivo. A desídia é a desatenção reiterada, desinteresse contínuo, o desleixo contumaz com as obrigações contratuais. Para autorizar a resolução culposa do contrato, exige, assim, regra geral, a evidenciação de um comportamento repetido e habitual do trabalhador, uma vez que as manifestações da negligência tendem a não ser tão graves, caso isoladamente consideradas. Neste quadro, a conduta desidiosa deve merecer exercício pedagógico do poder disciplinar pelo empregador com gradação de penalidade, em busca da adequada ressocialização do obreiro. Mostrando-se ineficaz essa tentativa de recuperação, a última falta implicará na resolução culposa do contrato de trabalho.

É claro que pode existir conduta desidiosa que se concentre em um único ato, excepcionalmente grave. Embora não se trate da regra geral, se isso ocorrer, não há que se falar em gradação de penalidades. 339

\subsubsection{Na legislação estadual}

O Estatuto dos Funcionários Públicos Civis do Estado, Lei ${ }^{\circ} 10.261$, de 28 de outubro de 1968, além da maioria das figuras também encontradas no estatuto federal, conta com a previsão específica e expressa de penalização por ineficiência, à qual é cominada a pena de demissão (artigo 256, III).

O primeiro aspecto a se notar no caso é que a lei em questão não faz menção à desídia e que o $\S 2^{\circ}$ dispõe que a pena de demissão somente será aplicada no caso em que for impossível a readaptação do funcionário.

Ocorre que a mesma lei define readaptação como a investidura em cargo mais compatível com a capacidade do funcionário, que dependerá sempre de inspeção médica (artigo 41). O Decreto $\mathrm{n}^{\mathrm{o}}$ 52.968, de 7 de julho de 1972, que regula tal procedimento, complementa tal ideia ao estabelecer que "a readaptação verificar-se-á sempre que ocorra modificação do estado físico ou mental do funcionário que venha a alterar sua capacidade para o trabalho" (artigo $\left.1^{\circ}\right)$.

Vê-se, portanto, que a readaptação no âmbito estadual, assim como no âmbito federal (artigo 24), é instituto destinado àqueles que se tornam limitados para o exercício da função até então exercida, por incapacidade física e mental adquirida, aferida mediante conhecimento médico, diferentemente, por exemplo, do que previa o antigo Estatuto dos Funcionários Públicos da União, Decreto-Lei n ${ }^{\circ} 1.713$, de 28 de outubro de 1939, que não

\footnotetext{
${ }^{339}$ DELGADO, Mauricio Godinho. op. cit., p. 1196-1197.
} 
previa a readaptação como sanção e a conceituava como "o aproveitamento do funcionário em função mais compatível com sua capacidade física ou intelectual e vocação" (artigo $68)^{340}$. Por este último dispositivo, a readaptação era destinada justamente para aquelas situações em que a função atribuída ao funcionário não correspondia a sua capacidade mental, sua vocação ou sua habilitação profissional (artigo 69). A mesma lei previa a pena de demissão àquele que agisse com ineficiência ou falta de aptidão para o serviço, quando fosse impossível a sua readaptação (artigo 238 , IV e $\S 3^{\circ}$ ).

Comparando-se os dois textos normativos, verifica-se que a hipótese de readaptação tratada na atual lei estadual se destina tão somente para os casos médicos. Assim, a readaptação, uma vez relacionada com tal circunstância médica, estaria fora de contexto ao ser colocada como pena ao lado da demissão no estatuto estadual. Sabe-se que, tratando-se de incapacidade física ou mental, a impossibilidade de readaptação deverá acarretar, assim como previsto no atual estatuto federal (artigo 24, $\S 1^{\circ}$ ), a aposentadoria por invalidez (artigo 222, I), e não a demissão, que se trata de penalidade administrativa por infração cometida.

Uma vez excluída a readaptação como pena e destinando-a apenas àqueles que gozam de limitação médica e considerando que as pessoas acometidas dessas incapacidades não podem se sujeitar à demissão, mas apenas à readaptação ou aposentadoria, resta analisar o conteúdo remanescente da ineficiência colocada ao lado de outras infrações.

Para tanto, veremos como tal instituto é tratado nas decisões administrativas do estado de São Paulo para daí extraírmos sentido da ineficiência na lei estadual.

Digitada a palavra ineficiência no banco de dados da Assessoria Jurídica do Governo do Estado de São Paulo ${ }^{341}$, que possui pareceres elaborados a partir de 1995 , apareceram 110 resultados, dos quais a maioria das infrações tratadas envolvia outros incisos do Estatuto ou ilícitos penais. Nessa pesquisa, constatou-se que poucos tratavam efetivamente de infração decorrente de ineficiência pura, sem acréscimo de nenhum outro inciso ou configuração de outra infração, e que a maioria se referia ao disposto no artigo 74, III da Lei Orgânica da Polícia Civil, Lei Complementar nº 207, de 5 de janeiro de 1997,

\footnotetext{
${ }^{340}$ CAVALCANTI, Themístocles Brandrão. O funcionário público e seu estatuto. Rio de Janeiro: Freitas Bastos, 1940. p. 440.

${ }^{341}$ Pesquisa realizada dia 21.9.2009.
} 
que prescreve o tipo "ineficiência intencional e reiterada no serviço". Todos estão mencionados a seguir.

Foi demitido por ter sido considerado como incurso na infração do artigo 74, III da Lei Complementar $n^{\circ} 207 / 97$, isto é, ineficiência intencional e reiterada no serviço, o fato de um Perito Criminal ter deixado de confeccionar 528 laudos em um período de dois anos, apesar de ter sido instado para tanto. Nesse caso, ficou constatado que, apesar das adversidades estruturais que o setor passava, o desempenho do servidor se mostrou inferior ao de seus colegas, que enfrentavam as mesmas dificuldades ${ }^{342}$. Também foi capitulado nesse artigo a conduta de determinado Delegado de Polícia que atrasou inúmeros inquéritos policiais e deixou vários boletins de ocorrência engavetados ${ }^{343}$. No mesmo sentido, foi capitulado no mesmo artigo o atraso na elaboração de laudos de forma reiterada, sendo que, neste caso, a penalidade foi suspensão ${ }^{344}$.

Em outra situação, a capitulação neste mesmo tipo infracional se deu por consequência lógica da capitulação nos artigos 62, I e II e 63, IX da lei já referida, isto é, por inassiduidade ${ }^{345}$. Um pouco diferente foi a situação na qual a inassiduidade, somada a diversas condenações anteriores pelo mesmo motivo, ensejou a capitulação no artigo 74, III da lei, em razão de o funcionário não ter avisado com antecedência que faltaria em determinado dia, em que houve fuga de $\operatorname{presos}^{346}$.

Cumpre destacar que, nas hipóteses acima mencionadas, a lei aplicável aos casos expressamente atribui o elemento intencional e de repetição à conduta, de sorte que, para que haja a condenação do servidor, é imprescindível a existência do dolo. Por isso, conduta parecida com as acima mencionadas foi reclassificada para o artigo 74, II, (procedimento

\footnotetext{
${ }^{342}$ Parecer no $1119 / 2008$, DGP-10.935/2005-SSP, vols. I a III, Despacho do Governador, de 11.9.2008 - DOE. de 12.9.2008 - Seção II - pág. 01.

${ }^{343}$ Parecer no ${ }^{\circ}$ 1201/1999, DGP-13.910/97-SSP, Vols. I a III, Despacho do Governador, de 15.12.99 - DOE. de 16.12 .99 - Seção II - pág. 02.

${ }^{344}$ Parecer n ${ }^{\text {o }}$ 1298/2005, DGP-4.459/04-SSP, vols. I ao III, Despacho do Governador, de 13.10.2005 - DOE. de 14.10.2005 - Seção II - pág. 01; Parecer no 1796/2004, DGP-7.022/2002-SSP, Vols. I ao III, Despacho do Governador, de 11.1.2005 - DOE. de 12.1.2005 - Seção II - pág. 01.

${ }^{345}$ Parecer no 1133/1998, DGP-4.522/94-SSP - Vols. I e II. Houve discordância, entretanto, de tal conclusão, pela Chefia da Assessoria Jurídica, pelo entendimento de que a inassiduidade não remeteria por si só à ineficiência, pois, ao comparecer, o servidor pode desempenhar sua atividade com eficiência. (Parecer $\mathrm{n}^{\circ}$ 0986/1999, DGP-6.322/97-SSP, Vols. I e II, DESP. DO GOV. DE 25/10/1999 - DOE. DE 26/10/1999 SEÇÃO II - PÁG. 01. No mesmo sentido: Parecer no 0844/1999, $3^{\text {a }}$ CPP-39/93-SE - c/aps. SE-2.844/93 + 9 PASTAS, Desp. do Gov. de 28/09/1999 - DOE de 29/09/1999 - Seção II - pág. 1 e 2.

${ }^{346}$ Parecer n ${ }^{\circ} 1159 / 1997$, DGP-10.547/94-SSP.
} 
irregular de natureza grave), pois constatou-se a existência de negligência, sem a presença de dolo, tendo sido mantida, entretanto, a pena de demissão ${ }^{347}$.

A negligência de servidores não foi enquadrada como ineficiência intencional e reiterada, porque somente poderiam ser assim demitidos se fosse dada prévia oportunidade de encaixá-los em serviço no qual se adaptassem, nos termos do artigo 256, $\S 2^{\circ}$ do Estatuto dos Funcionários Públicos ${ }^{348}$. Nesses casos, o instituto da readaptação foi utilizado sem que houvesse problema médico dos funcionários.

Com relação ao Estatuto dos Funcionários Públicos Civis do Estado de São Paulo, pouquísimas decisões foram encontradas a respeito do tema. Há parecer no qual se deixou de enquadrar determinada conduta no artigo 256, III, do Estatuto (ineficiência no serviço), para enquadrá-la no inciso II (procedimento irregular de natureza grave), porque teria faltado a continuidade nas irregularidades praticadas pelo funcionário ${ }^{349}$. Em outro caso, porque a irregularidade, pela sua gravidade, não se enquadrava nas pequenas e contínuas ilicitudes a que aludiria a ineficiência, a falta também foi desqualificada ${ }^{350}$.

Em um determinado parecer, houve o enquadramento no artigo 256, III, porque, mesmo tendo sido punido anteriormente com pena de suspensão, o agente público não demonstrou ter se recuperado, o que demonstraria a possibilidade de nova reincidência. $\mathrm{O}$ fato que ensejou a punição foi a responsabilidade in vigilando e in eligendo do superior em relação a funcionário de cartório que deveria ter sido substituído após a apuração, pela corregedoria, de inúmeras irregularidades ${ }^{351}$. Há outras decisões no mesmo sentido de ser

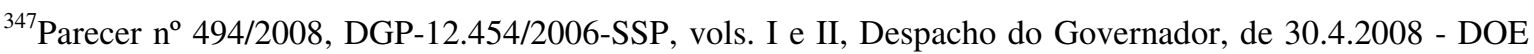
de $1^{\circ} .5 .2008$, Seção II, p. 01. No mesmo sentido: Parecer n ${ }^{\circ}$ 1052/2001, DGP-9.552/99-SSP, Vols. I e II Despacho do Governador, de 30.8.2001 - DOE. de 31.8.2001 - Seção II - pág. 01; Parecer nº 0683/2001, DGP-12.714/96-SSP, Vols. I a III, Despacho do Governador, de 22.6.2001 - DOE. de 23.6.2001 - Seção II - pág. 01.

${ }^{348}$ Parecer no 0567/2002, DGP-7.138/98-SSP, Vols. I e II, Despacho do Governador, de 29.5.2002 - DOE. de 30.5.2002 - Seção II - pág. 03. No mesmo sentido: Parecer no 1086/2001, DGP-15.259/99-SSP, Vols. I a V Despacho do Governador de 11/09/2001 - publicado DOE de 12/09/2001 - Seção II - pág. 1; Parecer $n^{\circ}$ 0244/2001, SJDC-256.469/97, Vols. I ao IV c/ aps. SJDC-256.469/97, I, II e III - INSTAURAÇÃO DE TOMADA DE CONTAS, REF. AOS ADIANTAMENTOS GS e DA (Cópia) + OF. PJ-1.568/2001 Despacho do Governador, de 14.3.2001 - DOE. de 15.3.2001 - Seção II - pág. 01; Parecer no 0209/2001, GS-1.120/95-SAP, Vols. I a III; 0186/2001, $2^{\text {a }}$ CPP-34/96-SE c/ aps. SE-1.584/96 + OF. 38/96-SE.

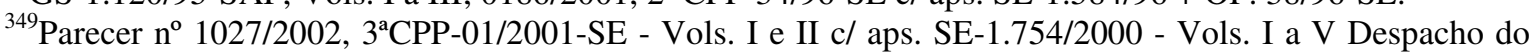
Governador, de 24.9.2002 - DOE. de 25.9.2002 - Seção II - pág. 02.

${ }^{350}$ Parecer n ${ }^{\circ}$ 0284/2001, $2^{\text {a }}$ CPP-39/98-SE, Vols. I a XII, c/ aps. 1.050/819/97 + 1.790/819/97+ $1.837 / 819 / 97+1.905 / 97+1.649 / 819 / 97+1.855 / 819 / 97+2.101 / 819 / 87+2.007 / 819 / 97+2.006 / 819 / 97+$ $2.005 / 819 / 97+1.980 / 819 / 97$ - Todos SE + SE-1.249/98, Vols. I a III Cópia do SE-1.438/819/96, Vols. I a III + Cópia do OF. MP nº 6.599/98, de 11.09.98 + 17 Cadernos+ Despacho do Governador, de 26.3.2001 DOE. de 27.3.2001 - Seção II - pág. 01.

${ }^{351}$ Parecer no 0285/2000, SJDC-260.265/99, Vols. I a III, Despacho do Governador, de 29.3.2000 - DOE. de 30.3.2000 - Seção I - pág. 02.
} 
tipificada a ineficiência por haver inúmeras outras punições anteriores do funcionário sem a demonstração de sua efetiva recuperação ${ }^{352}$. Em outro parecer, entretanto, constou que as penalidades anteriores devem servir apenas para fim de agravante, e não para tipificação na infração de ineficiência ${ }^{353}$.

Veja-se, portanto, que o dispositivo de lei é pouco utilizado, principalmente aquele do Estatuto dos Funcionários Públicos Civis do Estado, e quando o é, há sempre a necessidade de repetição da conduta considerada ineficiente. Tais características se assemelham à desídia da lei federal.

Como vimos, o estatuto federal não faz menção expressa à eficiência ou ineficiência nos deveres e proibições a que estão submetidos os funcionários, mas refere-se à proibição de atuação desidiosa, bem como faz previsão do dever de zelo e dedicação. No estatuto estadual, por sua vez, não há menção à desídia, mas tão somente à ineficiência e ao dever de zelo e presteza.

Pois bem, pelo que se demonstrou até agora, constata-se que a ineficiência possui as mesmas características da desídia prevista na lei federal. A ausência de prescrição relativa à desídia na lei estadual e, da ineficiência na lei federal, enaltece o fato de que os institutos se equivalem, havendo, apenas, uma forma diferente de se nomear o mesmo comportamento.

Assim como na desídia, é imprescindível a presença do elemento culpa na infração do artigo 256, III do Estatuto Estadual, pois sem ele não há infração. O princípio da culpabilidade integra o ius puniendi, sendo uma exigência para a aplicação da sanção ${ }^{354}$, pois "a intenção é o que move o homem durante a ação"355.

Celso Antônio Bandeira de Mello ensina que não se pode considerar a ocorrência de infração se inexistia, pelo menos, a possibilidade, pelo sujeito, de prévia eleição, in concreto, do comportamento que o livraria da incidência da infração, sendo, portanto, necessário, ao menos, o ânimo ${ }^{356}$. Isto é, a pessoa se move pelo livre arbítrio, não podendo lhe ser imposta qualquer penalidade, se não pôde ter controle sobre a evitabilidade ou não dos resultados.

\footnotetext{
${ }^{352}$ Parecer $n^{\circ}$ 0081/2000, DGP-9.754/97-SSP, Vols. I e II c/ ap. Pte. 01 do GS-4.515/98, Despacho do Governador, de 11.2.2000 - DOE. de 12.2.2000 - Seção II - pág. 01.

${ }^{353}$ Parecer no $1095 / 1996$, DGP-10.051/92-SSP - Vols. I e II.

${ }^{354}$ HUERGO LORA, Alejandro. Las sanciones administrativas, cit., p. 362 e 378.

${ }^{355}$ OSÓRIO, Fábio Medina. Teoria da improbidade administrativa: má gestão pública, corrupção e ineficiência, cit., p. 65.

${ }^{356}$ MELLO, Celso Antônio Bandeira de. Curso de direito administrativo, cit., p. 848.
} 
O ânimo, no sentido de liberdade na realização da conduta, o elo psicológico do comportamento, é incontestável que deve haver, senão a punição perderia a razão de ser ${ }^{357}$. No que se refere ao dolo e à culpa, entretanto, o entendimento é controvertido.

O dolo e a culpa são aspectos que integram a culpabilidade do agente. A culpabilidade seria a consciência e a vontade na prática do ato. No dolo, o agente quer realizar o resultado ou assume o risco de produzi-lo. A culpa no direito penal, ao contrário da culpa do direito civil, é admitida excepcionalmente e consiste na "prática voluntária de uma conduta, sem a devida atenção ou cuidado, da qual deflui um resultado previsto na lei como crime, não desejado nem previsto, mas previsível"358. Seria constituída por imprudência, imperícia e negligência.

Observa Paulo José da Costa Júnior: "No crime culposo, não se censura o agente por ter feito aquilo que não desejava. A reprovação advém do emprego de meios inadequados e perigosos, que produziram o fim não desejado"359.

A necessidade de presença da culpabilidade na infração administrativa, de acordo com a doutrina, possui os mais diversos fundamentos. Um deles é o princípio da individuação da pena, pelo qual, na mensuração da pena ao caso concreto, deve ser considerado, além de diversos outros fatores de ordem objetiva e subjetiva, os princípios humanitários, como o da culpabilidade, que não podem sofrer restrições pelo legislador ${ }^{360}$.

A exigência de culpabilidade para a imposição de sanções é garantida constitucionalmente, diante da consagração do conjunto de garantias individuais contra um poder sancionador arbitrário do Estado, que despreze a subjetividade da conduta. Além disso, a culpabilidade está prevista constitucionalmente na responsabilidade civil do agente público (artigo 37, $\S 6^{\circ}$ ), sendo mais do que coerente tal exigência se estender ao campo punitivo disciplinar, que atinge maior gama e direitos fundamentais mais relevantes ${ }^{361}$.

No entanto, no direito disciplinar a culpa é configurada no seu mais leve grau.

Com relação ao assunto, Álvaro Lazzarini assim se manifesta:

Basta que o agente tenha procedido consciente e livremente ao praticar a ação ou ao cometer a omissão: é suficiente a mera culpa, sem

\footnotetext{
${ }^{357}$ OLIVEIRA, Regis Fernandes de. Infrações e sanções administrativas, cit., p. 66.

${ }^{358}$ COSTA JÚNIOR, Paulo José da. Direito penal objetivo: comentários atualizados. 4 ed. Rio de Janeiro: Forense Universitária, 2006. p. 39-42.

${ }^{359}$ Id. Ibid., p. 42.

${ }^{360}$ NOBRE JUNIOR, Edilson Pereira. Sanções administrativas e princípios de direito penal. Revista de Direito Administrativo, Rio de Janeiro, n. 219, p. 142, jan./mar. 2000.

${ }^{361}$ OSÓRIO, Fábio Medina. Direito administrativo sancionador, cit., p. 430-435.
} 
necessidade de intenção. Assim, quanto ao elemento moral, a falta não precisa exteriorizar maldade, desejo de causar dano, intenção de violar leis e regulamentos. Pode tratar-se de improficiência, torpor, lentidão, inoportunidade, negligência ou omissão prejudicial ao funcionamento do serviço, conforme o magistério de Gaston Jeze. ${ }^{362}$

Se o objetivo do poder disciplinar é a prestação adequada do serviço público, não há outra conclusão a ser tomada. É que, se fosse necessária a intenção dolosa, isto é, desejar que os resultados ocorram, muitas condutas, ainda que reiteradas, praticadas por relapso, desatenção, negligência, imperícia e imprudência não iriam receber a punição merecida. Sem esses elementos, entretanto, não deve haver punição ${ }^{363}$.

Decorre da função pública a exigência de diligência.

A culpa se relaciona com a ausência de adoção de precauções necessárias a evitar o dano. Objetiva-se, desse modo, a culpabilidade, no sentido de que a concretização de evento incompatível com o dever de diligência induz a ocorrência de uma vontade defeituosa. A ocorrência do evento danoso é uma demonstração de culpa, porque não teria ele ocorrido se o sujeito tivesse adotado as providências impostas pelo dever de diligência que o onerava. ${ }^{364}$.

A valoração da culpa sempre estará sujeita a juízo de intuição, sem que seja possível uma apreciação objetiva, de forma que para se substituir a apreciação subjetiva criou-se a figura abstrata do homem médio ou do bonus pater familia, pela qual analisa-se a situação de acordo com a postura que teria o homem da sociedade com grau de inteligência, habilidade, energia, cultural e de instrução médio ${ }^{365}$.

Marçal Justen Filho observa, entretanto, que não se aplica ao exercício da função pública o modelo de atuação do bonus pater familia, pois o agente está obrigado a cumprir não apenas os padrões médios de diligência, mas sim atender às exigências mais rigorosas, com a observação da mais alta especialização ${ }^{366}$.

Também para Guido Falzone, no campo público, não se aplica o conceito de homem médio que vigora nas relações civis, pois os interesses de importância coletiva não se

\footnotetext{
${ }^{362}$ LAZZARINI, Álvaro. Estudos de direito administrativo, cit., p. 400.

${ }^{363} \mathrm{~A}$ intenção não precisa ser no sentido de se prejudicar ou boicotar o bom andamento do serviço público, mas tão somente a consciência da ilicitude e da conduta desidiosa, conforme Parecer PA n ${ }^{\circ} 2172005$, SSP/DGP n ${ }^{\circ} 4.459 / 2004$ - I ao III volumes (GDOC 14192-56313/2004).

${ }^{364}$ JUSTEN FILHO, Marçal. op. cit., p. 853.

${ }^{365}$ COSTA JÚNIOR, Paulo José da. op. cit., p. 43.

${ }^{366}$ JUSTEN FILHO, Marçal. op. cit., p. 789.
} 
contentam com uma ação normal, um comportamento médio, que esteja entre a má e a ótima administração; há de se encontrar, no direito administrativo, parâmetro similar àquele que configure o "bom administrador", que represente aquele que, no desenvolvimento da atividade administrativa inerente ao exercício da função, qualifique a atividade administrativa mediana, observadas as particularidades deste campo público. A média no campo público não é a mesma das relações privadas ${ }^{367}$.

É certo que, com base na realidade das situações jurídicas, algumas circunstâncias exigem maior cuidado que outras ${ }^{368}$. No entanto, concordamos com Onofre Alves Batista Júnior, que entende que não se pode esperar que os agentes públicos sejam super-homens, mas sim que sejam eficazes, que superem a atuação mediana mediante o desempenho acurado e escrupuloso das funções, que sejam selecionados mediante critérios calcados no mérito e na capacitação pessoal ${ }^{369}$.

Assim, deve-se estabelecer o comportamento médio entre os funcionários públicos, isto é, deve-se aplicar uma solução que leve em consideração o comportamento a ser adotado por outros funcionários no exercício da mesma função, diante da mesma situação e que possuam as habilitações e conhecimentos técnicos exigidos, pelo Estado, para o exercício do cargo. Não se pode exigir o comportamento de uma pessoa normal da sociedade e tampouco algo que supere a falibilidade natural do ser humano ${ }^{370}$.

Assim é que, para se aferir o comportamento médio esperado de determinado agente, deve haver, sobretudo, comparação com o comportamento médio de seus pares, que trabalham nas mesmas condições e exercem exatamente o mesmo tipo de atividade que o infrator, sempre seguindo a seguinte lição: "Uma das fundamentais virtudes do homem público é a prudência, o bom julgamento, a preparação adequada para o exercício das funções, a cautela e o respeito para com as obrigações de não causar danos a terceiros em nome do Estado",371.

\footnotetext{
${ }^{367}$ FALZONE, Guido. Il dovere di buona amministrazione: parte I, cit., p. 62.

${ }^{368}$ BEVILAQUA, Clovis. Theoria geral do direito civil. 6. ed. actualizada por Achilles Bevilaqua. Rio de Janeiro: Ed. Paulo de Azevedo, 1953. p. 353.

${ }^{369}$ BATISTA JÚNIOR, Onofre Alves. Princípio constitucional da eficiência administrativa, cit., p. 339.

${ }^{370}$ Ferraz, ao tratar do Tribunal de Contas em raciocínio que também se aplica ao presente estudo. (FERRAZ, Luciano. Tribunal de Contas - controle de serviço concedido, cit., p. 439-455. jan./mar. 2005).

${ }^{371}$ OSÓRIO, Fábio Medina. Teoria da improbidade administrativa: má gestão pública, corrupção e ineficiência, cit., p. 112.
} 


\subsection{Controle judicial sobre a aplicação da pena por ineficiência}

\subsubsection{Controle judicial sobre a ineficiência administrativa}

O controle judicial sobre a atividade administrativa era tradicionalmente circunscrito à legalidade do ato, consubstanciada na competência, forma e licitude do objeto, sob pena de, extrapolado tal limite, haver violação da Separação de Poderes consagrada nas diversas Constituições.

Não tardou, entretanto, para se perceber que tal controle era insuficiente para conter os abusos do Estado e se reconhecer que a análise de outros aspectos, além de essencial para a preservação do ordenamento jurídico como um todo, nada mais fazia do que contribuir para a preservação e consolidação do próprio princípio da Separação de Poderes.

Há, entretanto, no ato administrativo discricionário, uma margem de escolha afeta exclusivamente à Administração Pública, na qual incide a discricionariedade, que é denominada mérito. A doutrina o caracteriza como a oportunidade e a conveniência do ato. É a "parte" do ato na qual apenas o administrador, em contato com o caso concreto e com a realidade, possui o discernimento necessário para avaliar qual a melhor solução para a situação apresentada. Tradicionalmente, no mérito do ato administrativo não caberia ingerência do Poder Judiciário, ou seja, estaria afastado o controle judicial, porque sobre ele há plena discricionariedade.

Atualmente, entende-se que a possibilidade de análise do mérito do ato administrativo pelo Poder Judiciário continua se restringindo aos limites da legalidade. Ocorre, entretanto, que a legalidade, hoje, possui conteúdo muito mais amplo, abrangendo todo o ordenamento jurídico, no qual se inserem, inclusive, todos os princípios constitucionais, entre eles o da eficiência ${ }^{372}$. Essa dimensão principiológica, conferida pelo ordenamento jurídico, autoriza um exame qualificado da decisão administrativa.

Germana de Oliveira Moraes explica que a introdução de diversos princípios no

\footnotetext{
${ }^{372}$ Anteriormente, o entendimento era outro na jurisprudência: STJ, RMS no 628-0/RS, Ministro Milton Luiz Pereira, DJ 18.10.1993; STJ, ROMS 628-RS, Ministro Milton Luiz Pereira, DJ 18.10.1993, p. 21835; STJ ROMS 1.288-SP, DJ 2.5.1994, p. 09964, Ministro César Asfor Rocha; TRF, AC 90.01.08984-4-DF, DJ 3.6.1993, p. 21.133; STJ, ROMS 9.319-MS, DJ 12.4.1999, p. 00099, Ministro Garcia Vieira. Há, hoje, entretanto, decisões que mencionam o princípio da eficiência e a possibilidade de ingerência: STJ, Resp 144.750-SP, DJ 25.9.2000, p. 68, Ministro Franciso Galvão; STJ, Resp. 169.876-SP, DJ 21.9.1998, p. 00070, Ministro José Delgado.
} 
texto constitucional acabou por fornecer novos parâmetros para a atuação administrativa, sujeitando o ato administrativo ao controle de legalidade e controle de juridicidade stricto sensu; este seria o exame da compatibilidade dos elementos discricionários com os princípios. Integrariam o exercício da discricionariedade, ainda, os parâmetros não positivados, que é o que sobraria após a observância de todos os parâmetros legais e principiológicos. Tais parâmetros não positivados, para ela, formam o mérito do ato administrativo e são insuscetíveis de controle judicial, pois consistem em considerações de ordem extrajurídica, critérios não positivados alheios à lei e aos princípios ${ }^{373}$.

Assim, para ela, o controle judicial se exerce em duas frentes, o de legalidade, que analisa a conformidade do ato com a norma, e o de juridicidade, que começa quando cessa o controle de legalidade e que analisa a compatibilidade do ato com os princípios. Esgotados esses dois, não há mais que se falar em interferência judicial no ato administrativo, restando uma margem insuscetível de controle, porque não parametrizada. Nesse sentido: “A densidade da sindicância pelo Poder Judiciário dos atos não vinculados depende diretamente do preenchimento semântico do conteúdo dos princípios constitucionais da Administração Pública"374.

Pois bem, tal autora considera que as regras da boa administração formam parâmetros não positivados. Tendo-se a eficiência como equivalente da boa administração, tem-se que, muito embora o princípio da eficiência, como expressão, integre os princípios constantes do texto constitucional, o fato é que, como visto, seu conteúdo não foi positivado, quer dizer, seu conteúdo não foi parametrizado por normas, exigindo valoração e complementação no caso concreto.

Portanto, utilizando-se do raciocínio da autora, é fácil notar que o princípio da eficiência possui dois aspectos: sua fixação como princípio e ausência de conteúdo definido. É certo que, como já observamos, o segundo aspecto não inviabiliza o primeiro, pois de todo conceito se extrai um conteúdo mínimo, e não é diferente com a eficiência.

A eficiência, como vimos, apesar de ser conceito jurídico aberto que contempla uma infinidade de significados, compreende um sentido mínimo, o qual é compreensível diante da situação concreta ou por meio de parâmetros extraíveis do ordenamento jurídico ou da

\footnotetext{
373“'Daí decorre a distinção entre discricionariedade e mérito, adstrito este último à valoração administrativa mediante parâmetros não positivados - oportunidade e conveniência, que refogem aos vetores fixados nas normas constitucionais e infraconstitucionais." (MORAES, Germana de Oliveira. Controle jurisdicional da administração pública. 2. ed. São Paulo: Dialética, 2004. p. 199).

${ }^{374}$ MORAES, Germana de Oliveira. Controle jurisdicional da administração pública, cit., p. 160.
} 
realidade.

O segundo aspecto, entretanto, é o que remanesce, o que será preenchido após o esgotamento da aplicação das regras e do conteúdo mínimo do princípio, é o que forma o mérito e é insuscetível de controle judicial, justamente porque não integra o conteúdo mínimo do conceito.

Percebe-se, portanto, que o critério a ser utilizado no controle judicial dos atos discricionários é o das zonas de certeza, mencionado no capítulo anterior.

Nesse sentido, é vedado o controle pelo Poder Judiciário, isto é, é vedada a anulação da opção feita pelo administrador, quando ela se encontrar na zona de dúvida, isto é, nas hipóteses em que perante a situação concreta, seja impossível reconhecer de maneira pacífica e incontroversa qual é a conduta eficiente e qual é a ineficiente. E quando isso se der, incabível o controle judiciário sobre o ato.

Já nos casos em que, dentro dos padrões normais, for possível se identificar qual providência é indiscutivelmente eficiente ou que seguramente não o é, abre-se espaço para o controle judicial, porque o controle estaria situado nos limites da legalidade, isto é, no conteúdo definível do princípio da eficiência.

Segundo Celso Antônio Bandeira de Mello:

Deveras: à perquirição judicial nunca assistirá ir além dos limites de significação objetivamente desentranháveis da norma legal, conquanto valendo-se desassombradamente das vias mencionadas.

O campo de apreciação meramente subjetiva - seja por conter-se no interior das significações efetivamente possíveis de um conceito legal fluido e impreciso, seja por dizer com a simples conveniência ou oportunidade de um ato - permanece exclusivo do administrador e indevassável pelo juiz, sem o quê haveria substituição de um pelo outro, a dizer, invasão de funções que se poria às testilhas com o próprio princípio da independência dos Poderes, consagrado no art. 2 da Lei Maior. $^{375}$

Em inúmeros casos será impossível conhecer com exatidão a providência ideal cabível, isto é, eficiente, e é exatamente nesta esfera que reside a real discricionariedade, a qual é insindicável pelo Poder Judiciário.

Sendo assim, o Poder Judiciário apenas poderia invalidar um ato, se ele fosse objetiva e inquestionavelmente inadequado para a produção dos efeitos visados no

\footnotetext{
${ }^{375}$ MELLO, Celso Antônio Bandeira de. Curso de direito administrativo, cit., p. 982.
} 
momento em que realizado o ato. Não poderá, entretanto, invalidá-lo, sob o argumento de que, entre todas as opções válidas, aquela adotada não era a melhor.

O Poder Judiciário somente pode exercer o controle negativo sobre o ato, não pode substituir o ato administrativo (sobrepor sua avaliação subjetiva à avaliação do administrador público $)^{376}$, mas apenas dizer que a melhor solução, incontroversamente, notoriamente, patentemente, objetivamente (com base em critérios substanciais, referenciais objetivados) não foi adotada, e deve emitir um juízo objetivo de como o administrador não deve agir, porque "não se poder admitir que o juiz substitua os seus critérios subjetivos pelos do administrador" ${ }^{\prime 377}$.

É claro que no âmbito judicial essa análise da eficiência ou ineficiência do ato encontra barreiras maiores que as existentes no âmbito administrativo. É que, dentro do contexto conhecido e cotidiano, muitas vezes, o administrador se vê em dificuldades em eleger a melhor alternativa para determinada situação, e o Poder Judiciário faz tal análise sob o completo desconhecimento da gigantesca realidade que se impõe na escolha. São inúmeros os interesses que devem ser balizados na atuação administrativa. Alguns que se manifestam de forma explícita, outros, de forma implícita, e há, ainda, aqueles que se sobrepõem a outros e outros que, embora relevantes, às vezes, ficam escondidos.

As necessidades da sociedade são enormes e constantes, sendo que, muitas, vezes, há dificuldade de se atender plenamente a todas elas. É nisso em que consiste a difícil tarefa de administrar, a realização de escolhas que exaltam determinados interesses em detrimento de outros, mas em prol de uma equalização global. Por isso, fequentemente as escolhas não são objetivas e adentram no âmbito da política ${ }^{378}$.

Muitas vezes, aquilo que se demonstra óbvio para quem analisa a situação de fora, nem sempre se revela óbvio para aquele que tem o conhecimento da realidade. É por isso que a atividade de controle dos atos administrativos não deve ocorrer quando não for possível se ater com o máximo de fidelidade à complexa realidade, a fim de se evitar o desvirtuamento de sua finalidade.

\footnotetext{
${ }^{376}$ ARAÚJO, Edmir Netto de. Controle interno e externo da Administração. Revista da Procuradoria Geral do Estado de São Paulo São Paulo, n. 63/64, p. 51-84, jan./dez. 2006.

${ }^{377}$ BATISTA JÚNIOR, Onofre Alves. op. cit., p. 512 e 514.

${ }^{378}$ Nesse sentido, o Superior Tribunal de Justiça já deixou de interferir em decisão administrativa referente ao prolongamento de linha de transporte coletivo, porque considerou que tal decisão discricionária afetava o mérito administrativo, baseada em critério de eficiência. (STJ, Resp. 422.674/DF, Ministro Castro Meira, $1 / 4 / 2008)$
} 
Quando a situação compreender conceitos e avaliações técnicas, haverá de ser reproduzido o processo lógico feito pela Administração Pública, dentro do contexto vivenciado no momento da decisão administrativa, para se analisar os resultados obtidos, com base no critério das zonas de certeza, sendo necessário, para tanto, o recurso a peritos e assistentes técnicos ${ }^{379}$.

Porém, como dito anteriormente, nem sempre o conhecimento técnico conduzirá à certeza quanto à eficiência da solução adotada, eis que muitas ciências, até as exatas, podem conter parâmetros dotados de relatividade ou que não exprimem um consenso. Nesse sentido, o auxílio a peritos e demais profissionais técnicos visa justamente encontrar a zona de certeza que autoriza a interferência judicial, quer dizer, a função primordial do perito, nesses casos, será analisar se a solução adotada pela Administração Pública é manifestamente ineficiente, isto é, se dentro da objetividade e dos conhecimentos técnicos adequados, a solução pode ser considerada, por todos os profissionais da área, péssima ou ineficiente ${ }^{380}$. Se restar mínima dúvida, não deve haver interferência.

Para a consolidação de todos esses processos, é imprescindível haja análise dos fatos (aspectos objetivos e subjetivos), dos objetivos visados e dos objetivos de fato alcançados pelo ato administrativo ${ }^{381}$. São as circunstâncias do caso concreto que guiam a função jurisdicional, de forma que tal questão converte-se inevitavelmente em uma questão de prova. "Fica a cargo de quem impugna o ato demonstrar que a providência tomada não realiza, in concreto, a perfeita satisfação do interesse tutelado em abstrato pela regra de direito. Se o fizer, o ato terá que ser fulminado pelo Judiciário porque revelada estará sua desconformidade com o direito" ${ }^{, 382}$.

Outra circunstância que deve ser considerada no controle judicial dos atos administrativos, sobretudo da eficiência, é que não se pode tomar como base para a análise dos resultados as informações e as consequências fáticas produzidas já conhecidas. Isto é, não se poderá reprovar a escolha que se revelar inadequada posteriormente, após o conhecimento de suas consequências. Muito cômoda seria a possibilidade de crítica e repugnância depois à realização do ato, quer dizer, após a ciência dos resultados obtidos

\footnotetext{
${ }^{379}$ BATISTA JÚNIOR, Onofre Alves. op. cit., p. 522.

${ }^{380}$ Id. Ibid., p. 522.

${ }^{381}$ Nesse sentido é a conclusão que chega Bugarin, ao analisar a possibilidade de controle dos atos administrativos pelo Tribunal de Contas, situação que se assemelha a que ora se estuda, pois ambas envolvem a questão da Separação de Poderes. (BUGARIN, Paulo Soares. O princípio constitucional da economicidade na jurisprudência do Tribunal de Contas da União. Belo Horizonte: Fórum, 2004. p. 215).

${ }^{382}$ MELLO, Celso Antonio Bandeira de. O controle judicial dos atos administrativos, cit., p. 1-15.
} 
com o ato produzido. Seria exigir do administrador a onisciência, o dom de prever o futuro $^{383}$.

No controle judicial, revela-se importante a processualidade do ato administrativo tratada no capítulo anterior, pois a formação do ato administrativo por etapas proporciona um controle de forma fragmentada, culminando com limites substanciais mais rigorosos à atividade administrativa, às vezes, antes da consolidação do ato.

Desse processo de produção do ato administrativo, destacam-se outros aspectos da eficiência na atuação administrativa que podem ser controlados, inclusive, nos atos vinculados. É que, na atividade vinculada, o legislador pode fixar os meios (instrumentos) e os fins (interesses) da competência, sendo, entretanto, que o manuseio destas determinações pode não se revelar satisfatório, exsurgindo-se, daí, a ineficiência.

Como vimos, o manejo dos elementos vinculados pode se revelar indevido, quando não utilizados da forma ou na medida correta, acarretando deficiência, que pode ser constatada na produtividade, qualidade e celeridade. A ineficiência, neste caso, estaria no defeito de grau de atuação dos agentes públicos.

\subsubsection{Controle judicial sobre a aplicação da pena administrativa}

A questão da discricionariedade administrativa ganha especial relevo no que se refere ao exercício do poder disciplinar, já que se encontra nas suas duas principais etapas: na subsunção do fato à norma e na aplicação da pena adequada.

É importante lembrar as palavras de Fábio Medina Osório, no sentido de que o desconhecimento ou o esquecimento do regime jurídico e da natureza das sanções administrativas pode acabar "gerando precedentes jurisprudenciais perigosos" e projetando “o enfraquecimento do próprio Estado, através do descrédito de seus institutos" 384 . E isso se aplica, evidentemente, à preservação da discricionariedade administrativa, pelo Poder Judiciário, no âmbito disciplinar ${ }^{385}$.

Por força da atuação discricionária, sabe-se, que, em tese, o Poder Judiciário

\footnotetext{
${ }^{383}$ JUSTEN FILHO, Marçal. op. cit., p. 993 e 1002-1003.

${ }^{384}$ OSÓRIO, Fábio Medina. Direito administrativo sancionador, cit., p. 38.

${ }^{385}$ STJ, ROMS 7.290-RO, DJ 25.11.1996, p. 46.212, Ministro José Dantas.
} 
somente pode controlar o ato administrativo, anulando-o, nunca o substituindo ${ }^{386}$.

Por isso, no que se refere à penas, o controle se realiza sobre os aspectos atinentes à incompetência da autoridade, à inobservância das formalidades essenciais, à ilegalidade da sanção disciplinar e à inexistência de causa legítima que autorize a imposição da penalidade ${ }^{387}$.

O funcionário apenado disciplinarmente, que não se conforme com a sanção disciplinar, pode buscar, no Poder Judiciário, uma solução para a sua situação. Ao Poder Judiciário não caberá modificar a penalidade, substituindo-a por outra, mesmo mais branda. Como focalizado, a escolha da pena aplicável se encerra no poder discricionário que detém o Administrador que exerce o poder disciplinar. E o mérito dessa escolha não pode ser atacado, ou melhor, não pode ser examinado pelo Poder Judiciário. Este só pode verificar se a pena está dentre aquelas relacionadas na lei ou regulamento disciplinar a que se sujeite o faltoso. Poderá verificar, também se invocado, o cerceamento ao direito de defesa, em qualquer de seus matizes, como também se a motivação da sanção corresponde à realidade fática, verificando, ainda, a existência de qualquer outro vício insanável a ensejar a nulidade do ato administrativo punitivo. ${ }^{388}$

Dentro desta possibilidade de controle do poder disciplinar pelo Poder Judiciário está inserida a análise do respeito ao devido processo legal em sua vertente processual e substancial. Por meio deste princípio, que possui conteúdo bastante amplo, abrangendo diversos direitos fundamentais, proibe-se a arbitrariedade, a injustiça, a irrazoabilidade e diversas outras atitudes punitivas que destoem dos ideários de justiça, igualdade e proteção dos interesses individuais legítimos ${ }^{389}$.

A redução do controle judicial à análise da legalidade em sentido estrito resultaria a quebra da segurança jurídica e da certeza do direito, "posto que sob o manto da legalidade, seria possível editar ato sem suporte nas provas coligidas aos autos do processo" ${ }^{\text {390 }}$. Assim, outros aspectos devem também ser enfrentados. Vejamos.

"A análise dos pressupostos de fato que embasaram a atuação administrativa é recurso impostergável para aferição do direito e o juiz, neste caso, mantém-se estritamente

\footnotetext{
${ }^{386}$ AgRg no RMS 13.984, Ministra Laurita Vaz, DJ 6/8/2007.

${ }^{387}$ STF, Mandado de Segunraça n ${ }^{\circ}$ 20.999, DJU 25.5.1999.

${ }^{388}$ LAZZARINI, Álvaro. op. cit., p. 409.

${ }^{389}$ OSÓRIO, Fábio Medina. Direito administrativo sancionador, cit., p. 203-214.

${ }^{390}$ MARTINS, Eliezer Pereira. Segurança jurídica e certeza do direito em matéria disciplinar - aspectos atuais, cit., p. 141-152.
} 
em sua função quando procede ao cotejo entre o enunciado legal e a situação concreta"391 . Isso porque a existência do fato da maneira como considerado é condição para se aferir a adequação do ato administrativo e a sua consequente obediência à norma ${ }^{392}$. Deve-se verificar se houve subsunção do fato à norma e correlação lógica entre os suportes materiais do ato e o ato praticado, além do fim que deveria ser perseguido pela norma ${ }^{393}$. Imprescindível a análise do motivo do ato disciplinar ${ }^{394}$ e isso, muitas vezes, se faz mediante a análise das provas produzidas no processo administrativo ${ }^{395}$.

As decisões administrativas também devem corresponder ao princípio da congruência, devem aquilatar, acolhendo ou rejeitando, as teses fundamentais das partes, sob pena de arbitrariedade. ${ }^{396}$

Dentro deste denominado controle judicial está, ainda, a observância do princípio da proporcionalidade, previsto no artigo $2^{\circ}$, parágrafo único, inciso VI da Lei ${ }^{\circ}$ 9.784/99, pela Administração Pública "seja na adequação típica das condutas às descrições das normas, seja na atenuação dos rigores sancionatórios abstratos”397, podendo, tais aspectos, sofrer controle pelo Poder Judiciário.

Fábio Medina Osório assim resume a aplicação de tal princípio: “O princípio da proporcionalidade exige o exame da natureza do ataque ao bem juridicamente protegido e a sanção prevista a esse ataque. A sanção deve estar relacionada ao bem jurídico protegido" $" 398$.

Embora reconheça que são princípios próximos, Fábio Medina Osório explica a diferença entre proporcionalidade e razoabilidade. $\mathrm{O}$ primeiro tem origem germânica e se liga mais com o princípio do Estado de Direito, enquanto o segundo tem origem na Common Law e conecta-se à ideia do devido processo legal substancial, acima mencionada, tratando-se, ainda, de critério de interpretação com base em categorias padronizadas como

\footnotetext{
${ }^{391}$ MELLO, Celso Antônio Bandeira de. Curso de direito administrativo, cit., p. 969.

${ }^{392}$ VITTA, Heraldo Garcia. Aspectos da imposição de penalidades administrativas. Revista do Tribunal Regional Federal da $3^{a}$ Região, São Paulo, n. 78, p. 31-48, jul./ago. 2006.

${ }^{393}$ MS 21.297/DF, Ministro Marco Aurélio, DJ 28/2/1992, p. 2170)

${ }^{394}$ STF, RMS 24699/DF, Ministro Eros Grau, DJ 1/7/2005, p. 56; RE 100.750/PE, Ministro Djaci Falcão, DJ 9/12/1983, p. 19424.

395“O juiz pode e deve descer ao exame das provas nos processos administrativos." (TASP, RDA 58/56)

"Provas colhidas no processo administrativo podem ser examinadas pela Justiça." (STF, DRA 74/200)

${ }^{396}$ OSÓRIO, Fábio Medina. Direito administrativo sancionador, cit., p. 535-538.

${ }^{397}$ Quer dizer, tanto as penas, como os tipos devem ser proporcionais (aos bens jurídicos que protegem). (OSÓRIO, Fábio Medina. Direito administrativo sancionador, cit., p. 222).

${ }^{398}$ Id. Ibid., p. 249.
} 
o comportamento do homem médio ou a noção do bom administrador público ${ }^{399}$.

Humberto Ávila assim resume a diferença entre tais institutos:

Com efeito, o exame da razoabilidade-equivalência investiga a relação entre duas grandezas ou entre uma medida e o critério que informa sua fixação. $\mathrm{O}$ exame de proporcionalidade investiga a relação entre a medida adotada, a finalidade a ser atingida e o grau de restrição causado nos direitos fundamentais atingidos. $\mathrm{O}$ exame da proibição de excesso analisa a existência de invasão no núcleo essencial de um princípio fundamental. ${ }^{400}$

Para o autor, "o postulado da proporcionalidade aplica-se nos casos em que exista uma relação de causalidade entre um meio e um fim concretamente perceptível"401 , isto é, estabelece uma estrutura formal de eficácia, consiste em uma estrutura formal de relação meio-fim ${ }^{402}$.

Por meio da proibição de excesso também se analisa se a sanção é adequada, "no exame da proibição de excesso analisa-se a norma que institui a intervenção ou exação para comprovar se algum princípio fundamental não está sendo atingido no seu núcleo", independentemente de se analisar uma relação de causalidade entre um meio e um fim ${ }^{403}$.

Para Humberto Ávila, a razoabilidade impõe que as condições pessoais e individuais dos sujeitos envolvidos sejam consideradas na decisão, ou seja, faz com que a situação individual seja observada na determinação das consequências normativas. Para o autor, "a razoabilidade traduz uma condição material para a aplicação individual da justiça." Luis Roberto Barroso explica, sobre o princípio da razoabilidade, que ele é um parâmetro de razão que leva à justiça; trata-se de um princípio subjetivo, que é mais fácil de ser sentido do que ser conceituado ${ }^{404}$.

Tais princípios também refletem na necessidade de a Administração Pública atuar de maneira menos lesiva possível na aplicação de pena, pautando-se pelas balizas da

\footnotetext{
${ }^{399}$ OSÓRIO, Fábio Medina. Direito administrativo sancionador, cit., p. 220-221.

${ }^{400}$ Esse último instituto mencionado tem sido utilizado na jurisprudência associado à proporcionalidade e com a liberdade de comércio. Indica que as restrições aos princípios fundamentais não podem atingir seu núcleo essencial. (ÁVILA, Humberto. Conteúdo, limites e intensidade dos controles de razoabilidade, de proporcionalidade e de excessividade das leis. Revista de Direito Administrativo, Rio de Janeiro, n. 236, p. 369-384, abr./jun. 2004).

${ }^{401}$ ÁVILA, Humberto. Teoria dos princípios: da definição à aplicação dos princípios jurídicos, cit., p. 182.

${ }^{402}$ Id. A distinção entre princípios e regras e a redefinição do dever de proporcionalidade. Revista de Direito Administrativo, Rio de Janeiro, n. 215, p. 151-179, jan./mar. 1999.

${ }^{403}$ Id. Teoria dos princípios: da definição à aplicação dos princípios jurídicos, cit., p. 137 e 146.

${ }^{404}$ BARROSO, Luis Roberto. Os princípios da razoabilidade e da proporcionalidade no direito constitucional. Cadernos de Direito Constitucional e Ciência Política, São Paulo, v. 6, n. 23, p. 65-78, abr./jun. 1998.
} 
necessidade e da adequação ${ }^{405}$.

Seja como for, independentemente do enquadramento que se dê aos institutos, eles merecem aplicação na atuação do poder disciplinar e no seu respectivo controle, na medida em que representam a aplicação de todo um ordenamento jurídico, o qual não deve ficar fora do controle judicial, conforme a jurisprudência ${ }^{406}$.

\subsection{Parâmetros gerais para a tipificação e a punição da ineficiência do funcionário público}

De tudo o que se viu, é possível perceber que não faltam normas legais que prescrevam a consequência de quebra do vínculo profissional do funcionário com o Estado no caso de comportamentos ineficientes.

A Constituição Federal prevê o estágio probatório e a avaliação periódica de desempenho. Em ambas, há o rompimento do vínculo que liga o funcionário com o Estado, sendo certo que, apesar de não ser caracterizado como infração, afeta o indivíduo em um dos seus aspectos da personalidade. Exceto quanto ao aspecto da culpabilidade, que não precisa estar presente nesses dois casos, os parâmetros que traçaremos a seguir também se aplicam a esses casos.

Antes, porém, é necessário observar que, atualmente, a diferença entre essas duas situações é que, no estágio probatório, o funcionário deve receber acompanhamento e orientação de perto, podendo haver, inclusive, maior tolerância com relação a alguns erros, sendo certo que a própria Administração Pública possui um dever mais concentrado no sentido de fornecer o acompanhamento e as orientações, possibilitando ao funcionário a segurança e a certeza de saber qual é o caminho e as condutas que são esperadas pela Administração Pública. Com relação ao segundo, o que se visa evitar é justamente a acomodação do funcionário pela aquisição da estabilidade e a manutenção de sua preocupação com as atividades que estão sendo desenvolvidas, evitando-se, assim, o comportamento ineficiente.

\footnotetext{
${ }^{405}$ PALERMO, Fernanda Kellner de Oliveira. O princípio da proporcionalidade e as sanções penais nos contratos administrativos. Revista de Direito Administrativo, Rio de Janeiro, n. 227, p. 321-337, jan./mar. 2002.

${ }^{406}$ STF, MS 24.901/DF, Ministro Carlos Britto, DJ 11/2/2005, p. 13; RMS 13.346/BA, Ministro Felix Fischer, DJ 5/11/2001; MS 6.663/DF, Ministro Fernando Gonçalves, DJ 2/10/2000; MS 8106/DF, Ministro Vicente Leal, DJ 28/10/2002; RMS 10.316/SP, Ministro Vicente Leal, DJ 22/5/2000.
} 
Além disso, a dispensa pela avaliação de desempenho pode implicar em uma extensão de suas consequências, já que pode afetar o superior que inseriu ou tenha mantido o funcionário eficiente no exercício das funções. Ademais, se aplica mediante a repetição dos atos indevidos. É a oportunidade para se analisar a contribuição do funcionário para o desenvolvimento das atividades, comparando seu comportamento com o de seus pares, sendo certo que, se o seu desempenho se apresentar manifestamente inferior ao deles e, após as devidas tentativas de correção e orientação, o mesmo não melhorar, o funcionário deverá ser exonerado.

Com relação às infrações de desídia e de ineficiência que constam, respectivamente, das leis federal e estadual, tem-se que as mesmas se equivalem.

Passaremos, então, a ver quais são os parâmetros que se extraem deste trabalho que podem nortear a atuação do julgador ao fazer a subsunção do comportamento a referido tipo.

Em primeiro lugar, as condutas não podem ser individualmente analisadas, devendo ter sempre como foco a amplitude do contexto em que a atividade se desenvolve, focando o olhar para as instituições ${ }^{407}$. Assim, a apuração da conduta indevida deve relacionar e analisar detalhamente se, quando da realização do comportamento do infrator, o funcionário tinha à sua disposição todos os instrumentos que o Estado deve oferecer para a condução de uma atividade eficiente. No caso de deficiência no fornecimento de algum desses instrumentos, deve-se analisar a relação e o impacto que tal deficiência acarretou no comportamento analisado.

Deve-se verificar, também, se os outros colegas que exercem as mesmas funções se encontravam na mesma situação e qual foi ou seria o comportamento esperado dos mesmos diante da situação analisada.

$\mathrm{Na}$ atuação discricionária, a atuação ineficiente do funcionário é verificada mediante a análise da escolha que realizou, levando-se em consideração as informações das quais dispunha e o momento da escolha.

Aqui, o que se expôs sobre o controle judicial sobre a eficiência terá grande valia para o desenvolvimento do parâmetro, pois a conduta do julgador deve se valer do mesmo critério das zonas de certeza e incerteza para fazer a subsunção do comportamento do funcionário ao ilícito da desídia ou ineficiência. É que, diante da atuação discricionária, na

\footnotetext{
${ }^{407}$ OSÓRIO, Fábio Medina. Direito administrativo sancionador, cit., p. 55.
} 
qual há diversas situações possíveis e igualmente válidas, o critério do julgador administrativo não poderá substituir o critério utilizado pelo funcionário, salvo quando houver alguma norma ou diretriz administrativa a ser seguida. Nesse sentido, somente poderá ser considerada ineficiente aquela escolha que se mostrar com certeza ineficiente. Se houver alguma dúvida sobre a sua ineficiência, a conduta do funcionário não poderá ser tipificada.

$\mathrm{Na}$ atividade vinculada, a ineficiência será constatada quando houver deficiência na produtividade, qualidade ou celeridade, sempre se levando em consideração os fatores que podem influenciar na atuação do funcionário e acarretar a realização de atos ineficientes, tal como a ausência dos instrumentos necessários para o cumprimento destes três aspectos, bem como o comportamento e a situação de seus pares, a fim de que se faça uma análise ampla e aberta da situação.

Geralmente, a ineficiência será constatada mediante a conduta reiterada ${ }^{408}$, ainda que não seja sempre a mesma, revelando o desleixo contumaz. No entanto, excepcionalmente, poderá decorrer de uma única conduta, dependendo da situação que se apresente, revelando o descuido momentâneo.

$\mathrm{O}$ ato praticado deve ser analisado no contexto da atuação global do funcionário que, a despeito de um ato ineficiente, pode ter exercido suas funções sempre de forma eficiente, angariando resultados positivos para a Administração Pública. Deve-se, portanto, equilibrar as atuações positivas e negativas, devendo a pena ser aplicada tão somente quando a balança pesar para o lado negativo ou, pelo menos, se equilibrar. A previsão da ineficiência como ilícito administrativo não constitui um fim em si mesmo, mas pretende apenas destacar um valor a ser protegido pelo ordenamento jurídico, permitindo a proteção de um bem considerado importante, o regular e eficiente andamento das atividades administrativas. Não se pode esperar, entretanto, que o administrador público possa ser um otimizador sistemático de decisões ${ }^{409}$.

O imprescindível é ter em mente, ainda, o critério do comportamento médio esperado dos funcionários, isto é, deve-se tomar como base a conduta do administrador mediano, como parâmetro prático de sindicância ${ }^{410}$.

\footnotetext{
${ }^{408}$ STJ, MS no 10.220/DF, Ministro Arnaldo Esteves Lima, DJU 13.8.2007.

${ }^{409}$ Decisão do Tribunal de Constas da União, Processo n. TC 147/95-6, extraída da Revista de Direito Administrativo. Rio de Janeiro, n. 213, p. 281-318, jul./set. 1998.

${ }^{410}$ BATISTA JÚNIOR, Onofre Alves. op. cit., p. 339.
} 
Há de ser considerada, ainda, a margem de falibilidade funcional, consistente no “erro profissional”, isto é "erro juridicamente tolerável" "111. Além disso, deve-se analisar o "grau da falha apontada e bem assim sua repercussão nos valores jurídico-administrativos, inclusive para aquilatar o tipo e o tamanho da resposta a ser dada"412.

Não se pode esquecer, ainda, que para que haja a tipificação do ilícito em questão, é imprescindível que esteja presente o elemento culpa, pois a relação de sujeição especial não autoriza a mitigação de garantias consideradas individuais. Assim, tanto na atividade discricionária como na vinculada, a ineficiência punida será aquela que decorreu da imprudência, negligência e imperícia.

Há dificuldade em se precisar sem subjetividade o cumprimento dos deveres de zelo, presteza e dedicação ${ }^{413}$, isto é, a culpa em si, na medida em que falta um padrão objetivo, havendo apenas "um apelo à consideração do esforço possível ao trabalhador em concreto na execução das funções do seu posto de trabalho", de sorte que o parâmetro a ser utilizado deverá observar as qualidades, a experiência, a idade, a formação profissional do trabalhador e as exigências da função a ele confiada, etc. ${ }^{414}$

$\mathrm{Na}$ aplicação da pena, tem-se que devem ser observados os parâmetros que passaremos a identificar.

Em primeiro lugar, a prevenção deverá estar presente. Assim, deverá o julgador analisar se tal acontecimento ineficiente era previsível e se a Administração Pública realizou algum movimento que direcionasse a conduta do funcionário. Em caso negativo, é necessário verificar se, caso a Administração Pública tivesse procedido à devida orientação, o comportamento se realizaria da mesma forma ou não.

No momento da aplicação da pena disciplinar, deve-se ter em mente a finalidade para a qual se destina sua aplicação. Nesse sentido, a pena deve ser precedida da correção, quando o comportamento permitir, sem que haja prejuízos para a instituição, de forma que o funcionário se anime em aperfeiçoar seu trabalho e a Administração Pública poupe tempo, energia e dinheiro com a realização de processo sancionatório e a contratação e

\footnotetext{
${ }^{411}$ OSÓRIO, Fábio Medina. Teoria da improbidade administrativa: má gestão pública, corrupção e ineficiência, cit., p. 271.

${ }^{412}$ Id. Ibid., p. 66-67.

413، A dificuldade de sanção reside exatamente na pouca objetividade com que os deveres deste artigo são insculpidos na lei. Não sendo de objetiva imposição, nenhuma objetiva exigibilidade os atinge." (RIGOLIN, Ivan Barbosa. Comentários ao Regime Único dos Servidores Públicos Civis. 3. ed., atual. São Paulo: Saraiva, 1994. p. 206).

${ }^{414}$ Segundo Macedo, que trata de instituto semelhante no direito laboral privado espanhol (desinteresse do trabalhador). (MACEDO, Pedro de Sousa. Poder disciplinar patronal, cit., p. 92).
} 
adaptação de funcionários que venham substituir aquele penalizado.

Assim, uma vez detectada uma atuação contumaz ineficiente, é imprescindível haver o encaminhamento do agente para aperfeiçoamento, sendo que, somente após esgotadas as possibilidades de aperfeiçoamento e após sua reinserção em condições adequadas na sua função, apontando-se qual é o comportamento que a Administração Pública espera do agente, é que será possível a aplicação de penalidades, podendo ser estas, inclusive, gradativas, até a exclusão do agente renitente dos quadros.

Já escreveu Marcello Caetano, há muito tempo: "Tão grave é castigar um funcionário por incompetente, que o superior só depois de tôdas as tentativas de correcção e de decorrido um período largo de adaptação, deve instaurar o processo disciplinar" ${ }^{\natural 15}$.

Vê-se, portanto, que a atuação da Administração Pública direcionada ao funcionário público, como já falamos anteriormente, deve ser realizada de forma conjunta e integrada. Todos os instrumentos previstos em norma, integrados, se afiguram, em tese, eficazes ao alcance da eficiência, focando-se a atenção no funcionário público. Um efetivo e eficaz investimento no aperfeiçoamento e treinamento do funcionário, por exemplo, além de torná-lo mais capacitado, refletindo em uma maior segurança na sua atuação, bem como na qualidade e na produtividade do serviço apresentado, pode, até mesmo, tornar o sistema punitivo mais rigoroso, pois o nível de exigência requerido do servidor se eleva.

Por outro lado, nada adiantam previsões legais, que, apesar de se mostrarem aptas a uma efetiva mudança na dinâmica da Administração Pública, nunca foram efetivamente implantadas ou testadas ou, ainda, iniciativas isoladas, sem qualquer integração com um contexto do sistema inteiro, como a avaliação periódica prevista pela Constituição Federal.

Desta forma, todos os institutos previstos no ordenamento jurídico devem ser utilizados para analisar qual a contribuição do profissional para o perfeito funcionamento da organização. São uma excelente forma de resolver problemas e aperfeiçoar as atividades $\operatorname{administrativas~}^{416}$. Note-se, ainda, que todo profissional espera um retorno sobre seu desempenho, sem o qual o mesmo caminha às cegas, sem correções, sem reconhecimentos e, ainda, sem o exercício de suas potencialidades.

\footnotetext{
${ }^{415}$ CAETANO, Marcelo. Do poder disciplinar no direito administrativo português, cit., p. 67.

${ }^{416}$ CHIAVENATO, Idalberto. Gestão de pessoas: e o novo papel dos recursos humanos nas organizações, cit., p. 223.
} 
Sobretudo, é preciso estar aberto para inovações que sempre levem ao caminho da melhor alternativa para que seja almejado, senão atingido, o ideal de eficiência ${ }^{417}$.

De tudo que se expôs, pode parecer que a presente perspectiva, bem como os parâmetros apontados, é paternalista com relação aos funcionários, mas o fato é que, se o estágio probatório, a avaliação periódica de desempenho e a aplicação das penalidades pela desídia e ineficiência não fossem subtilizadas, como de fato são, tais parâmetros poderiam ser testados de forma tal que a ideia de eficiência neles subsumida se incorporaria na cultura e na mentalidade dos administradores e administrados, de forma hábil a conferir ao funcionário público estímulo suficiente a proporcionar a entrega de uma atividade que traria plena satisfação dos administrados.

${ }^{417}$ Ver experiência narrada em FERRAZ, Luciano. Controle consensual da administração pública e suspensão do processo administrativo disciplinar (SUSPAD) - a experiência do município de Belo Horizonte. Interesse Público: revista bimestral de direito público, Belo Horizonte, v. 9, n. 44, p. 15-25, 2007. 


\section{CONCLUSÕES}

1- Para que o Estado consiga satisfazer todos os deveres prescritos na Constituição Federal é imprescindível que aja com eficiência.

2- São os agentes públicos que exteriorizam a vontade e as atividades do Estado. Portanto, é por meio de sua atuação que a eficiência do Estado é analisada, tendo eles papel essencial nesse processo.

3- Os agentes públicos são aqueles que agem em nome do Estado.

4- Servidores públicos são aqueles que prestam serviços ao Estado mediante relação de trabalho, não eventual, sob vínculo de dependência econômica e se submetem à hierarquia e à subordinação.

5- A adoção do regime estatutário ou celetista deve levar em conta a natureza da atividade a ser desenvolvida pelo servidor público.

6- Aqueles que exercem atividade típica e exclusiva do Estado e possuem uma relação da qual avultam interesses públicos básicos são os funcionários públicos; eles são regidos por estatuto, que confere garantias para uma atuação imparcial e obediente ao interesse público.

7- Aqueles que exercem atividades atípicas, funções materiais, subalternas, destituídas de relevância política, não essenciais à satisfação dos direitos fundamentais e que não necessitam de maior consistência jurídica, são os empregados públicos, regidos pelo regime trabalhista/celetista.

8- O poder disciplinar se desenvolveu de forma autônoma com relação aos demais poderes punitivos do Estado (direito penal e poder de polícia), tendo decorrido do desenvolvimento da própria estrutura administrativa, que existe desde os primórdios das relações humanas com o fito de garantir o desenvolvimento e a paz da coletividade.

9- A disciplina é a base para se garantir a paz, o progresso e o alcance das finalidades de um grupo.

10- A partir da Revolução Francesa, as relações dos agentes com o Estado, e, por conseguinte, o poder disciplinar, passou a se estruturar juridicamente, tendo nascido, daí, a responsabilidade dos agentes de forma normatizada.

11- A responsabilidade administrativa disciplinar decorre da relação de sujeição especial. 
12- Relação de sujeição especial se diferencia da relação de supremacia geral, pois esta é estabelecida entre o Estado e todos os cidadãos de forma indistinta. Na relação de sujeição especial há um vínculo peculiar, estrito, direto, imediato, acentuado e específico entre o Estado e determinados cidadãos, que a ele se submetem por vontade própria, tal como o vínculo profissional.

13- A ideia de que alguns princípios de direitos fundamentais poderiam ser mitigados na aplicação do poder disciplinar nas relações de sujeição especial não se coaduna com o interesse público contido na atividade administrativa e tampouco como atual Estado de Direito.

14- Os princípios constitucionais podem, entretanto, ter aplicações diversas conforme tipo de poder punitivo a ser exercido pelo Estado (penal, polícia ou disciplinar), variando e se adaptando de acordo com as características ou peculiaridades de cada regime, adequando-se às respectivas realidades.

15- Ilícito administrativo é o comportamento contrário a um dever jurídico estabelecido ou que se enquadra no tipo infracional descrito na norma.

16- O ilícito é prescrito em função do bem comum, quer dizer, para se manter a ordem, impedindo a realização de atos indesejados.

17- Sanção é a retribuição impingida como consequência da realização do ato ilícito, que atua como desvantagem ao infrator, visando, com isso, conferir eficácia à norma e impedir a realização de atos não desejados pelo grupo.

18- A Constituição Federal de 1988 precisou se adaptar, por meio de inúmeras emendas, à tendência pela qual o Estado se concentra apenas nas atividades primordiais e imprescindíveis para a garantia do desenvolvimento das coletividades, deixando o resto para a atividade privada.

19- A Emenda Constitucional nº 19/98 promoveu inúmeras mudanças nesse sentido de abertura do setor público para o setor privado, promovendo outras mudanças destinadas ao alcance da eficiência, incluindo esta, inclusive, como princípio da Administração Pública.

20- A influência dos parâmetros e conceitos do setor privado deve ser analisada com ponderação na interpretação de referido princípio, descartando-se o cunho eminentemente econômico, mantendo-se, entretanto, as observações gerais feitas nos estudos da Ciência da Administração, na medida em que compatíveis com as peculiaridades da Ciência do Direito Administrativo. 
21- Assim, não se pode descartar as ideias de meio e fim que qualificam a eficiência na Ciência da Administração.

22- Como princípio constitucional, a eficiência não tem conteúdo definido, pois tratase de conceito jurídico indeterminado de cunho valorativo e abstrato, que possui como função o direcionamento de comportamentos, mediante a imposição de vetores axiológicos, que se situam acima de todas as normas, sendo, portanto, de observação prioritária e obrigatória.

23- Apesar de não possuir conteúdo absolutamente preciso, o princípio da eficiência possui um conteúdo mínimo, sobre o qual há consenso.

24- Sobre tal consenso, tem-se que, acima de tudo, ele existe para garantir a manutenção da dignidade da pessoa humana.

25- Apesar de não se ter visto mudanças concretas com a introdução do princípio da eficiência no texto constitucional, o fato é que não se pode desprezar que marca a introdução de uma nova concepção apta a promover o avanço cultural dos administrados e subsidiar atitudes e ideias inovadoras por parte dos administradores, uma vez que vincula imediatamente todos que a ele se submetem.

26- De tudo que se extrai da doutrina e da jurisprudência, é possível concluir que o princípio da eficiência consiste na adoção dos melhores meios para o alcance satisfatório do objetivo visado, consistente, esse, na garantia dos meios mínimos necessários para o desenvolvimento dos administrados e do progresso da coletividade, sempre com o fim de não se deixar desamparadas as necessidades imprescindíveis para a manutenção da dignidade da pessoa humana.

27- De seu conteúdo mínimo, ainda, não podem ficar de fora os conceitos ligados à eficiência que constam da Ciência da Administração: meio e fim, sem, entretanto, seja priorizado um sentido ou outro, devendo os mesmos ser utilizados em equilíbrio.

28- Enquanto a legislação não se encarrega de estabelecer suficientes parâmetros objetivos para sua exata determinação, assim como foi feito com o conceito cambiante de moralidade, a definição de eficiência deve se basear em parâmetros intuitivos e aproximativos e outros que se revelam essenciais e consensuais.

29- O dever de eficiência somente pode ser cobrado do funcionário público a partir do momento em que o mesmo tenha condições necessárias e suficientes que permitam esse agir. 
30- Há alguns instrumentos básicos que devem ser fornecidos pelo Estado para o cumprimento do dever de eficiência.

31- O instrumento organizacional é estabelecido por lei, após a escolha, pelo legislador, do método desenvolvido pela Ciência da Administração que lhe parecer mais adequado. Tal instrumento consiste na disposição e alocação dos elementos, funções e responsabilidades de forma a melhor se adequarem ao alcance da finalidade do grupo.

32- O instrumento operacional consiste na coordenação entre os elementos que fazem parte da organização de forma que permita o alcance do objetivo visado. Tal instrumento pode ser encontrado nos contratos de gestão, consórcios públicos ou convênios ou pode ser exercido no âmbito da própria estrutura hierárquica, atualmente vigente na Administração Pública, sempre por pessoa que goze do conhecimento técnico adequado.

33- Não se obtém eficiência sem um prévio planejamento, inserido no aspecto direcional.

34- O instrumento subjetivo trata da valorização do aspecto humano, os funcionários públicos, sem o qual nenhuma atividade é desenvolvida pelo grupo. Por meio de tal instrumento, é necessária constante renovação, distribuição adequada de trabalho, levando em consideração a qualidade de cada um e a função que exercerá.

35- O instrumento objetivo é a articulação e a coordenação dos diversos interesses secundários do Estado, exercido pelos diversos órgãos, de forma tal que seja possível o alcance da finalidade primária.

36- O instrumento material é o fornecimento de condições materiais que incentivem os funcionários ao aperfeiçoamento de sua atividade.

37- O instrumento estrutural é o fornecimento de ambiente e materiais adequados de trabalho, bem como de número suficiente de funcionários, que permitam o desenvolvimento das atividades da melhor forma possível.

38- O instrumento intelectual consiste no oferecimento, pelo Estado, de programas de aperfeiçoamento e obrigue, de forma positiva, a participação dos funcionários nos mesmos, para que a atividade administrativa esteja sempre em constante progresso.

39- O instrumento moral trata da necessidade de se estabelecer medidas preventivas aptas a livrar a Administração Pública da corrupção, o que, por conseguinte, acarreta o desenvolvimento mais eficiente da atividade administrativa. 
40- O instrumento cultural consiste na necessidade de se incutir no funcionário público a noção de que ele serve ao interesse coletivo e, no administrado, a consciência de que deve participar desse assunto, exercendo influência na busca pela eficiência.

41- O descumprimento de dever de eficiência pelo funcionário, quando houver, deve ser analisado em confronto com o dever do Estado no fornecimento de todos os instrumentos mencionados neste estudo, pois a eficiência somente pode ser constatada quando analisada de forma global.

42- Paralelamente aos instrumentos que devem ser fornecidos pelo Estado, ao funcionário cabe cumprir sua parte na sua atuação individual. Esta pode ser exercida de forma discricionária ou vinculada, sendo certo que, nas duas, está presente o dever de eficiência.

43- $\mathrm{Na}$ atividade discricionária, assim como na aplicação do conceito jurídico indeterminado e na denominada discricionariedade técnica, o exercício da discricionariedade se confunde com o exercício da eficiência, pois em ambos o que se visa é a escolha da melhor solução possível diante do caso concreto apresentado. Em todas as situações haverá um conjunto ou uma única solução que se mostrará consensualmente melhor e um conjunto ou uma única solução que, com certeza, não será melhor. Dentro do conjunto de soluções sobre o qual há dúvidas de ser ou não a melhor solução, haverá o que se chama de zona de incerteza, sobre a qual a escolha do administrador é livre.

44- Atualmente, o processo administrativo é uma forma de exercício do poder discricionário que valoriza a eficiência, pois contrabalança a garantia dos administrados e a eficiência, na medida em que representa a proteção do administrado contra atos arbitrários, desmotivados ou sem análise de todos os aspectos, e a modernização da máquina administrativa, por meio da celeridade e da economicidade.

45- Tendo em vista que a atividade discricionária coincide, e até se confunde, com o exercício do dever de eficiência, é possível se afirmar que é a na atividade vinculada que verdadeiramente há reflexos da introdução do princípio da eficiência no texto constitucional.

46- Na atividade vinculada, o dever de eficiência pode ser representado pela celeridade, quantidade e qualidade, sendo que todos esses elementos devem agir em equilíbrio, pois o prestígio de um em detrimento do outro, evidentemente, causa ineficiência do resultado final. 
47- A celeridade consiste no dever de produzir o ato em tempo adequado e suficiente para que o resultado surta os efeitos desejados.

48- A quantidade representa a produtividade, podendo ser aferida e mensurada de forma objetiva.

49- A qualidade detém diversos aspectos, como cortesia, neutralidade, perfeição, continuidade, aperfeiçoamento contínuo, etc., estando presente sempre que o administrado se mostrar satisfeito.

50- A finalidade do poder disciplinar é a ordem interna da Administração Pública, que permite a coordenação e o constante aperfeiçoamento dos trabalhos individuais para se alcançar os objetivos do Estado. Para haver disciplina, deve haver previsão de sanção.

51- As finalidades da pena administrativa disciplinar coincidem com as finalidades das penas em qualquer outro âmbito sancionatório estatal, pois todos visam a ordem e coesão do grupo. Consubstancia-se nas denominadas prevenção geral, prevenção especial e ressocialização.

52- A finalidade da pena deve, também, se afinar com a finalidade do próprio poder disciplinar. Nesse sentido, a utilização do poder disciplinar não pode ocorrer de forma que acarrete uma atuação ineficiente da atividade administrativa e, tampouco, pode ocorrer de forma que iniba condutas praticadas com intuito inovatório e positivo.

53- A ausência de aplicação da pena e a sua aplicação desponderada, além de desvirtuarem a finalidade do poder disciplinar, acarretam desestímulo aos funcionários públicos e implicam em uma consequente atuação ineficiente dos mesmos.

54- A aplicação desponderada da pena compreende diversos aspectos, entre eles, a demora na conclusão do processo sancionatório que acaba por tornar a pena desproporcional, já que a simples existência de processo em andamento aflige o funcionário público e torna-o mais vulnerável a interesses escusos.

55- As penas corretivas e pedagógicas são as que melhor contribuem para a realização da finalidade do poder disciplinar, na medida em que aperfeiçoa o comportamento do funcionário e o mantém no serviço, evitando-se, assim, perda de energia, tempo e dinheiro, com processos administrativos ou contratações de novos funcionários. É mais eficiente, também, porque atua de forma preventiva, evitando-se o prejuízo à Administração Pública pelo cometimento de outras infrações. 
56- A correção pode ser encontrada, até mesmo, na pena de demissão, sendo, por isso, vedada a proibição de reingresso do funcionário despedido em cargo público, pois isso implica em infligir pena perpétua, o que é vedado pelo ordenamento jurídico.

57- O poder disciplinar compreende, também, atitudes positivas por parte do Estado, que orientem e estimulem o funcionário a praticar os atos esperados pela Administração Pública.

58- Enquanto não se desenvolvem ou se aplicam formas de obtenção da eficiência por meio do poder disciplinar, o administrador deve ter em mente, pelo menos, os objetivos que as fundamentam e, principalmente, evitar o desestímulo dos funcionários públicos pelo uso do poder disciplinar. Assim, as penas disciplinares devem ser aplicadas somente após as devidas correções, orientações e condutas capazes de estimular uma conduta diferente.

59- Há diversos exemplos normativos em que o comportamento ineficiente acarreta a quebra do vínculo administrativo que liga o funcionário ao Estado.

60- Na Constituição Federal, há o estágio probatório e a avaliação periódica de desempenho. Em ambas, as consequências implicam em uma desvalia para o funcionário e podem macular seu futuro profissional, de forma que não se pode afastar o processo administrativo com todas as implicações principiológicas que dele decorrem.

61- Ambos os institutos são subtilizados e, em ambos, não é necessária a presença do elemento culpa para que o funcionário seja exonerado. A diferença entre eles é que, no estágio probatório, o funcionário deve receber acompanhamento e orientação de perto, podendo haver, inclusive, maior tolerância com relação a alguns erros. Com relação ao segundo, o que se visa evitar é justamente a acomodação do funcionário pela aquisição da estabilidade e a manutenção de sua preocupação com as atividades que estão sendo desenvolvidas, evitando-se, assim, o comportamento ineficiente.

62- A dispensa pela avaliação periódica pode implicar em uma extensão de suas consequências, já que pode afetar o superior que inseriu ou tenha mantido o funcionário ineficiente no exercício das funções. Além disso, se aplica mediante a repetição dos atos indevidos. É a oportunidade para se analisar a contribuição do funcionário para o desenvolvimento das atividades, comparando seu comportamento com o de seus pares; se seu desempenho se apresentar 
manifestamente inferior e, após as devidas tentativas de correção e orientação, não apresentar melhora, o funcionário deverá ser exonerado.

63- Na legislação federal, há a previsão do ilícito pela desídia que, em princípio, não acarreta demissão. A desídia é o contraposto do dever de zelo e dedicação, que consta da mesma lei, e se manifesta, principalmente, pela falta de diligência. Ligase, portanto, ao elemento culpa.

64- Na legislação estadual, a ineficiência é prevista como infração e o dever contraposto é o de zelo e presteza. Prevê a lei, como sanção, a pena de demissão, quando não for possível a readaptação.

65- A readaptação é destinada somente para os casos de incapacidade física ou mental, isto é, se relaciona a situações médicas. Nesse sentido, quando impossível a readaptação, segue-se a aposentadoria por invalidez, e não a demissão.

66- Retirando-se do conteúdo da norma a situação de incapacidade médica, na qual cabe a readaptação ou a aposentadoria, remanesce um conteúdo residual na norma, que corresponde à infração por ineficiência.

67- A ineficiência como infração, para a qual é prevista a demissão, de acordo com as decisões administrativas, corresponde a condutas reiteradas e culposas, pois o elemento culpa, por imposição do ordenamento jurídico, não pode ser afastado para efeito de punição.

68- A culpabilidade no direito disciplinar corresponde ao mais leve grau de culpa por imprudência, imperícia ou negligência, pois se assim não fosse, faltas comuns praticadas por servidores relapsos não seriam punidas.

69- Na análise da conduta do funcionário, deve-se levar em conta seu trabalho como um todo, sua atuação cotidiana e anterior e, principalmente, a atuação de seus pares que exercem as mesmas funções e trabalham nas mesmas condições que o funcionário infrator.

70- Pela análise dos dispositivos legais, percebe-se que a infração de ineficiência prevista na lei estadual refere-se ao mesmo comportamento tipificado como desídia na legislação federal, embora as conseqüências previstas nos dois sejam diferentes.

71- No controle judicial da eficiência, o critério a ser utilizado é o das zonas de certeza e de dúvida, isto é, somente poderá haver ingerência do Poder Judiciário no ato administrativo quando a sua opção estiver dentro da zona de certeza de que ele era absolutamente ineficiente. Não pode pairar nenhuma dúvida sobre isso, e, se houver dúvida, não poderá haver controle judicial. O mesmo vale para os casos em que a 
dúvida deve ser resolvida pela aplicação de alguma ciência. Nesse caso, o auxílio a peritos deve esclarecer se o ato realizado pela Administração Pública encontra-se na zona de certeza ou de dúvida e, com base nisso, poder-se-á determinar se haverá ou não controle judicial.

72- O controle judicial deve ser negativo, isto é, de anulação, nunca de substituição (do ato anulado por outro). Havendo a anulação, a oportunidade para que o ato seja refeito e substituído deve ser devolvida à Administração Pública.

73- Na atividade vinculada, a ineficiência é constatada na deficiência da quantidade, qualidade ou celeridade, podendo o Poder Judiciário intervir para suprir alguma dessas falhas.

74- No que se refere à aplicação das penas disciplinares, o Poder Judiciário poderá anular o ato que viole o ordenamento jurídico e seus princípios explícitos e implícitos, como o da proporcionalidade e o da razoabilidade, havendo, para tanto, a necessidade de se analisar os fatos, a motivação e, às vezes, as provas produzidas no processo administrativo.

75- De tudo que se expôs no trabalho é possível se concluir que são parâmetros para a subsunção do comportamento do funcionário à infração de ineficiência: 1 verificação se a Administração Pública forneceu todos os instrumentos necessários para que o funcionário exerça uma atividade eficiente e, em caso de deficiência no fornecimento de algum desses instrumentos, deve-se analisar a relação e o impacto que tal deficiência acarretou no comportamento analisado; 2- na atuação discricionária, a atuação ineficiente do funcionário é verificada mediante a análise da escolha que se realizou, levando-se em consideração as informações das quais o funcionário dispunha e o momento da escolha, utilizando-se o critério das zonas de certeza e incerteza ao avaliar se a conduta foi ou não ineficiente; 3 - na atividade vinculada, a ineficiência será constatada quando houver deficiência na produtividade, qualidade ou celeridade, sempre levando-se em consideração os fatores que podem influenciar na atuação do funcionário e acarretar a realização da ineficiência; 4- a reiteração das condutas, isto é, o desleixo contumaz, podendo haver, excepcionalmente, responsabilidade por descuido momentâneo; 5- presença do elemento culpa, isto é, a presença de imprudência, negligência e imperícia, ainda que de forma leve; 6- observação do comportamento de outros funcionários que atuem exatamente na mesma situação que o infrator, a fim de se extrair o padrão de conduta mediano e esperado do funcionário público; 7- a atuação global do 
funcionário que, a despeito de um ato ineficiente, pode ter exercido suas funções sempre de forma eficiente, angariando resultados positivos para a Administração Pública até então.

76- A aplicação da pena deve se basear nos seguintes parâmetros, entre outros tradicionais: 1- verificar se a Administração Pública se movimentou no que se refere à prevenção, orientando e direcionando a conduta do funcionário. Em caso negativo, é necessário verificar se, caso a Administração Pública tivesse procedido à devida orientação, o comportamento se realizaria da mesma forma ou não; 2precedência da correção, que permite ao funcionário aperfeiçoar seu trabalho.

77- Se os institutos legais, que visam evitar o comportamento ineficiente, forem devidamente utilizados, tais parâmetros poderão ser testados de forma tal que a idéia de eficiência neles subsumida se incorporará na cultura e na mentalidade dos administradores e administrados de forma hábil a conferir ao funcionário público estímulo suficiente a proporcionar a entrega da atividade pública eficiente, com a qual os administrados ficarão satisfeitos. 


\section{REFERÊNCIAS BIBLIOGRÁFICAS}

ADAMI, Mateus Piva. A discricionariedade administrativa em face do princípio da eficiência. 2007. Dissertação (Mestrado) - Faculdade de Direito, Universidade de São Paulo, São Paulo, 2007.

ALESSI, Renato. Sistema istituzionale del diritto amministrativo italiano. Milano: Giuffrè, 1953.

ALEXY, Robert. Teoría de los derechos fundamentales. Madrid: Centro de Estudios Políticos y Constitucionales, 2001.

ARAGÃO, Alexandre Santos. O princípio da eficiência. Revista de Direito Administrativo, Rio de Janeiro, n. 237, p. 1-6, jul./set. 2004.

ARAÚJO, Edmir Netto de. Controle interno e externo da Administração. Revista da Procuradoria Geral do Estado de São Paulo São Paulo, n. 63/64, p. 51-84, jan./dez. 2006.

. Curso de direito administrativo. 4. ed. São Paulo: Saraiva, 2009.

. Do negócio jurídico administrativo. São Paulo: Ed. Revista dos Tribunais, 1992.
$\frac{\text {. O ilícito administrativo e o seu processo. São Paulo: Ed. Revista dos Tribunais, }}{1994 .}$

ÁVILA, Humberto. Conteúdo, limites e intensidade dos controles de razoabilidade, de proporcionalidade e de excessividade das leis. Revista de Direito Administrativo, Rio de Janeiro, n. 236, p. 369-384, abr./jun. 2004.

A distinção entre princípios e regras e a redefinição do dever de proporcionalidade. Revista de Direito Administrativo, Rio de Janeiro, n. 215, p. 151-179, jan./mar. 1999.

- Teoria dos princípios: da definição à aplicação dos princípios jurídicos. 7. ed. ampl. e atual. São Paulo: Malheiros Ed., 2007.

BACELLAR FILHO, Romeu Felipe. Princípios constitucionais do processo administrativo disciplinar. São Paulo: Max Limonad, 1998.

BARBOSA, Sandra Pires. Impacto da globalização sobre o princípio da eficiência. Revista de Direito Administrativo, Rio de Janeiro, n. 224, p. 197-210, abr./jun. 2001.

BARCELlOS, Ana Paula de. Alguns parâmetros normativos para a ponderação constitucional. In: BARROSO, Luís Roberto (Org.). A nova interpretação constitucional: ponderação, direitos fundamentais e relações privadas.3. ed. rev. Rio de Janeiro: Renovar, 2008. 
BARCELlOS, Ana Paula de. A eficácia jurídica dos princípios constitucionais. 2. ed. ampl. rev. e atual. Rio de Janeiro: Renovar, 2008.

BARROS JÚNIOR, Carlos S. de. Do poder disciplinar na administração pública. 1969. Tese (Cátedra de Direito Administrativo) - Faculdade de Direito da Universidade de São Paulo, São Paulo, 1969.

BARROSO, Luís Roberto. Fundamentos teóricos e filosóficos do novo direito constitucional brasileiro (pós-modernidade, teoria crítica e pós-positivismo). In:

(Org.). A nova interpretação constitucional: ponderação, direitos fundamentais e relações privadas. 3. ed. rev. Rio de Janeiro: Renovar, 2008.

Os princípios da razoabilidade e da proporcionalidade no direito constitucional. Cadernos de Direito Constitucional e Ciência Política, São Paulo, v. 6, n. 23, p. 65-78, abr./jun. 1998.

BASTOS, Aline Maria Dias. Conceitos jurídicos indeterminados: discricionariedade ou vinculação? 2002. Dissertação (Mestrado) - Faculdade de Direito, Universidade de São Paulo, São Paulo, 2002.

BATISTA JÚNIOR, Onofre Alves. Princípio constitucional da eficiência administrativa. Belo Horizonte: Mandamentos, 2004.

BECCARIA, Cesare Bonesana. Dos delitos e das penas. Trad. Deocleciano Torrieri Guimarães. São Paulo: Rideel, 2003.

BEVILAQUA, Clovis. Theoria geral do direito civil. 6. ed. actualizada por Achilles Bevilaqua. Rio de Janeiro: Ed. Paulo de Azevedo, 1953.

BINENBOUN, Gustavo. Uma teoria do direito administrativo. Rio de Janeiro: Renovar, 2006.

BRANDÃO, Cláudio. Poder disciplinar: um direito penal administrativo? Revista da Esmape- Escola Superior da Magistratura do Estado de Pernambuco, v. 3, n. 7, p. 83-102, jan./jun. 1998.

BUGARIN, Paulo Soares. O princípio constitucional da economicidade na jurisprudência do Tribunal de Contas da União. Belo Horizonte: Fórum, 2004.

BULOS, Uadi Lammêgo. Reforma administrativa (primeiras impressões). Revista de Direito Administrativo, Rio de Janeiro, n. 214, p. 69-98, out./dez. 1998.

CAETANO, Marcelo. Do poder disciplinar no direito administrativo português. Coimbra: Imprensa da Universidade, 1932.

Manual de direito administrativo. 10. ed. 6 reimp. Coimbra: Livr. Almedina, 1999. v. 2. 
CAETANO, Marcello. Manual de direito administrativo. 10. ed. 8. reimp. Coimbra: Livr. Almedina, 2005. v. 1.

Princípios fundamentais do direito administrativo. Reimpressão da edição Brasileira de 1977, 2. reimpr. Portuguesa. Lisboa: Livr. Almedina, 2003.

CALHAO, Antônio Ernani Pedroso. O princípio da eficiência na administração da justiça. São Paulo: RCS Ed., 2007.

CANOTILHO, José Joaquim Gomes. Direito constitucional. 6. ed. rev. Coimbra: Livr. Almedina, 1993.

CARVALHO FILHO, José dos Santos. A discricionariedade: análise de seu delineamento jurídico. In: GARCIA, Emerson (Coord.). Discricionariedade administrativa. Rio de Janeiro: Lumen Juris, 2005.

CAVALCANTI, Themístocles Brandrão. O funcionário público e seu estatuto. Rio de Janeiro: Freitas Bastos, 1940.

CHIAVENATO, Idalberto. Administração dos novos tempos. 2. ed. 7. tir. Rio de Janeiro: Campus, 1999.

. Gestão de pessoas: e o novo papel dos recursos humanos nas organizações. 2. ed. totalmente rev. e atual. 5. reimpr. Rio de Janeiro: Elsevier, 2004.

Introdução à teoria geral da administração. 4. ed. São Paulo: Makron Books do Brasil; McGraw-Hill, 1993.

Recursos humanos: o capital humano das organizações. 8. ed. 4. reimpr. São Paulo: Atlas, 2008.

CHICÓSKI, Davi. O princípio da eficiência e o procedimento administrativo. Revista de Direito Administrativo, Rio de Janeiro, n. 237, p. 93-118, jul./set. 2004.

CINTRA, Adjair de Andrade. Prescrição penal e finalidades da pena. 2007. Dissertação (Mestrado) - Faculdade de Direito, Universidade de São Paulo, São Paulo, 2007.

COELHO, Paulo Magalhães da Costa. Manual de direito administrativo. São Paulo: Saraiva, 2004.

COSTA, José Armando da. Teoria e prática do direito disciplinar. Rio de Janeiro: Forense, 1981.

COSTA, Regina Helena. Conceitos jurídicos indeterminados e discricionariedade administrativa. Revista de Direito Público, São Paulo, ano 23, n. 95, jul./set. 1990.

COSTA JÚNIOR, Paulo José da. Direito penal objetivo: comentários atualizados. 4 ed. Rio de Janeiro: Forense Universitária, 2006. 
COSTIN, Cláudia Maria. Reforma administrativa e governabilidade. Colab. Paulo Rabello de Castro, Pedro Luiz Barros Silva, Miguel Reale Júnior. Extraído da mesa redonda sobre o tema "reforma administrativa e governabilidade", organizada pela Fundação KonradAdenauer-Stiftung na sede do Parlamento Latino-Americano, no dia 24 de abril de 1995. São Paulo: Fundação Konrad-Adenauer-Stiftung, 1995.

CRETELLA JÚNIOR, José. Curso de direito administrativo. 17. ed. rev. e atual. Rio de Janeiro: Forense, 2000.

CRETELLA JÚNIOR, José. Prática do processo administrativo. 6. ed. rev. e atual. São Paulo: Ed. Revista dos Tribunais, 2008.

CUSTODIO FILHO, Ubirajara. A Emenda Constitucional 19/98 e o princípio da eficiência na Administração Pública. Cadernos de Direito Constitucional e Ciência Política, São Paulo, v. 7, n. 27, p. 209-217, 1999.

DAL BOSCO, Maria Goretti Dal. Responsabilidade do agente público por ato de improbidade. Rio de Janeiro: Lumen Juris, 2004.

DALLARI, Adilson Abreu. Administração pública no Estado de direito. Revista Trimestral de Direito Público, São Paulo, v. 94, n. 5, p. 33-41, 1994.

Privatização, eficiência e responsabilidade. In: MOREIRA NETO, Diogo de Figueiredo (Coord.). Uma avaliação das tendências contemporâneas do Direito Administrativo. Rio de Janeiro: Renovar, 2003.

DALLARI, Dalmo de Abreu. Elementos de teoria geral do Estado. 19. ed. atual. São Paulo: Saraiva, 1995.

DELGADO, Mauricio Godinho. Curso de direito do trabalho. 6. ed. São Paulo: LTr, 2007.

DI PIETRO, Maria Sylvia Zanella. Direito administrativo. 22. ed. São Paulo: Atlas, 2009.

Discricionariedade administrativa na Constituição de 1988. 2. ed. 4. reimpr. São Paulo: Atlas, 2007.

Discricionariedade técnica e discricionariedade administrativa. Revista Brasileira de Direito Público - RBDP, Belo Horizonte, ano 5, n. 17, p. 75-96, abr./jun. 2007. . Inovações no direito administrativo. Interesse Público, Porto Alegre, n. 30, p. 3955, mar./abr. 2005.

. 500 anos de direito administrativo brasileiro. In: AMARAL, Ana Lucia; FRISCHEISSEN, Luiza Cristina Fonseca; COSTA, Paula Bajer Fernandes Martins da. (Coords.). Costa 500 anos e o direito no Brasil. São Paulo: Artchip Ed., 2000.

DIAS, Jefferson Aparecido. Princípio da eficiência \& moralidade administrativa. 2. ed. Curitiba: Juruá, 2008. 
DIAS, José de Nazaré Teixeira. A reforma administrativa de 1967. Rio de Janeiro: Fundação Getúlio Vargas, 1968. (Cadernos de Administração Pública n. 73).

FALCÓN Y TELLA, María José; FALCÓN Y TELLA, Fernando. Fundamento $e$ finalidade da sanção: existe um direito de castigar? Trad. AVENA, Claudia de Miranda, revisão de Flávio Luiz Gomes. São Paulo: Ed. Revista dos Tribunais, 2008.

FALZONE, Guido. Il dovere di buona amministrazione: parte I. Milano: Giuffrèe, 1953.

FERRAZ, Luciano. Controle consensual da administração pública e suspensão do processo administrativo disciplinar (SUSPAD) - a experiência do município de Belo Horizonte. Interesse Público: revista bimestral de direito público, Belo Horizonte, v. 9, n. 44, p. 1525, 2007.

- Tribunal de Contas - controle de serviço concedido. III seminário de direito administrativo controle das políticas públicas proteção do usuário. Controle pelos Tribunais de Contas da eficiência e eficácia dos serviços concedidos. Revista de Direito Administrativo, Rio de Janeiro, n. 239, p. 439-455. jan./mar. 2005.

FERRAZ JUNIOR, Tercio Sampaio. Introdução ao estudo do direito: técnica, decisão dominação. São Paulo: Atlas, 1988.

FIGUEIREDO, Lúcia Valle. Curso de direito administrativo. 8. ed. rev., ampl. e atual. São Paulo: Malheiros Ed., 2006.

Responsabilidade dos agentes políticos e dos servidores. Revista de Direito Administrativo, Rio de Janeiro, n. 196, p. 36-42, abr./jun. 1994.

FRANÇA, Vladimir da Rocha. Eficiência administrativa na Constituição Federal. Revista de Direito Administrativo, Rio de Janeiro, n. 220, p. 165-177, abr./jun. 2000.

FREITAS, Izaías Dantas. A finalidade da pena no processo administrativo disciplinar. Boletim de Direito Administrativo, São Paulo, ano 17, n. 8, p. 618-625, ago. 2001.

FREITAS, Juarez. Discricionariedade administrativa e o direito fundamental à boa administração pública. A sindicabilidade aprofundada dos atos administrativos. Os vícios de arbitrariedade por excesso ou omissão. A era da motivação administrativa. A responsabilidade do Estado por ações e omissões. A releitura de institutos à luz do direito à boa administração. Os princípios da prevenção e da precaução. $O$ EstadoAdministração, os objetivos fundamentais e o desenvolvimento humano. A valorização das Carreiras do Estado. 2. ed. São Paulo: Malheiros Ed., 2009.

GABARDO, Emerson. Princípio constitucional da eficiência administrativa. São Paulo: Dialética, 2002.

GARCIA, Mônica Nicida. Responsabilidade do agente público. Belo Horizonte: Fórum, 2007. 
GARCÍA DE ENTERRÍA, Eduardo; FERNÁNDEZ, Tomáz-Ramón. Curso de direito administrativo II. 9. ed. Madrid: Thomson Civitas, 2004.

GARRIDO FALLA, Fernando. Tratado de derecho administrativo: parte general: conclusion. 11. ed. Madrid: Tecnos, 1989. v. 2.

GASPARINI, Diógenes. Direito administrativo. 9. ed. São Paulo: Saraiva, 2004.

GAUS, John M. A theory of organization in public administration. GAUS, John M.; WHITE, Leonard D. DIMOCK, Marshall E. The frontiers or Public Administration. Illinois, Chicago: The University of Chicago Press, 1936.

GILISEN, John. Introdução histórica ao direito. 3. ed. Lisboa: Fundação Calouste Gunbenkian, 2001.

GOVERNMENT Performance Results Act of 1993. Disponível em: <http://www.whitehouse.gov/omb/mgmt-gpra/gplaw2m.html\#h9>. Acesso em: 19 fev. 2009.

GROTTI, Dinorá Adelaide Musetti. O serviço público e a Constituição brasileira de 1988. São Paulo: Malheiros Ed., 2003.

GUIMARÃES, Daniel Serra Azul. O princípio geral da eficiência na administração pública. 2007. Dissertação (Mestrado) - Pontifícia Universidade Católica de São Paulo, São Paulo, 2007.

HARGER, Marcelo. Princípios constitucionais do processo administrativo. 2. ed. rev. e atual. Rio de Janeiro: Forense; Gen, 2008.

HUERGO LORA, Alejandro. Las sanciones administrativas. Madrid: Iustel, 2007.

HUNGRIA, Nelson. Ilícito administrativo e ilícito penal. Revista de Direito Administrativo, Seleção histórica, Rio de Janeiro, 1945-1995.

JUSTEN FILHO, Marçal. Curso de direito administrativo. 4. ed. rev. e atual. São Paulo: Saraiva, 2009.

KELSEN, Hans. Teoria pura do direito. Trad. João Baptista Machado. 6 ed. Coimbra: Armênio Amado, 1984.

KRAUSPENHAR, Rogério. Os limites do poder disciplinar do empregador. São Paulo: LTr, 2001.

LACERDA, Paulo Francisco Bastos von Bruck. Fundamentos do processo administrativo disciplinar: justiça administrativa. 2004. Dissertação (Mestrado) - Faculdade de Direito, Universidade de São Paulo, São Paulo, 2004.

LAZZARINI, Álvaro. Estudos de direito administrativo. São Paulo: Ed. Revista dos Tribunais, 1999. 
LIMA, Ruy Cirne. Princípios de direito administrativo. 7. ed. rev. e reelaborada por Paulo Alberto Pasqualini. São Paulo: Malheiros Ed., 2007.

LOPES, Mauricio Antonio Ribeiro. Comentários à reforma administrativa: de acordo com as Emendas Constitucionais 18, de 05.02.1988, e 19, de 04.06.1998. São Paulo: Ed. Revista dos Tribunais, 1998.

LOUREIRO, João Carlos Simões Gonçalves. O procedimento administrativo entre a eficiência e a garantia dos particulares: algumas considerações. Boletim da Faculdade de Direito Universidade de Coimbra, Coimbra, 1995.

LUZ, Egberto Maia. Direito administrativo disciplinar: teoria e prática. 3. ed. rev., ampl. e atual. São Paulo: Ed. Revista dos Tribunais, 1994.

MACEDO, Pedro de Sousa. Poder disciplinar patronal. Coimbra: Livr. Almedina, 1990.

MAGALHÃES JÚNIOR, Antonio Silvio. $O$ controle da administração pública pelo Tribunal de Contas. 2005. Dissertação (Mestrado) - Faculdade de Direito, Universidade de São Paulo, São Paulo, 2005.

MALKUT, Rozeli Aparecida da Silva. O princípio da eficiência na Administração Pública brasileira. Revista Jurídica do UNIARAXÁ, v. 8, n. 7, 2004.

MARQUES NETO, Floriano de Azevedo. Processo administrativo inquisitorial: eficiência investigativa e garantias constitucionais. Revista de Informação Legislativa, Brasília, v. 42, n. 167, p. 191-211, jul./set. 2005.

MARTÍN-RETORTILLO Y BAQUER. Sebastián. El reto de una administración racionalizada. Madrid: Civitas, 1983.

MARTINS, Alzemeri; SOUZA, Marisa Idalência de. O princípio constitucional da eficiência, aplicação à função do Procurador do Estado no exercício da consultoria jurídica. Revista da Procuradoria Geral do Estado da Bahia, Salvador, v. 25, p. 59-98, jan./dez. 1999.

MARTINS, Eliezer Pereira. Segurança jurídica e certeza do direito em matéria disciplinar - aspectos atuais. Revista de Direito Administrativo, Rio de Janeiro, n. 230, p. 141-152, out./dez. 2002.

MARTINS JUNIOR, Wallace Paiva. A discricionariedade administrativa à luz do princípio da eficiência. Revista dos Tribunais, São Paulo, ano 90, v. 789, p. 62-89, jul. 2001.

MEDAUAR, Odete. Direito administrativo moderno. 12. ed. rev. atual. e ampl. São Paulo: Ed. Revista dos Tribunais, 2008.

MEIRELLES, Hely Lopes. Direito administrativo brasileiro. 33. ed. São Paulo: Malheiros Ed., 2007. 
MELLO, Celso Antônio Bandeira de. Apontamentos sobre os agentes e órgãos públicos. São Paulo: Ed. Revista dos Tribunais, 1972.

O controle judicial dos atos administrativos. Revista de Direito Administrativo, Rio de Janeiro, n. 152, p. 1-15, abr./jun. 1983.

Curso de direito administrativo. 26 ed. rev. e atual. até a Emenda Constitucional 57, de 18.12.2008. São Paulo: Malheiros Ed., 2009.

Discricionariedade e controle jurisdicional. 2. ed., 7. tir., São Paulo: Malheiros Ed., 2006.

MELLO, Oswaldo Aranha Bandeira de. Princípios gerais de direito administrativo: introdução. 3. ed. São Paulo: Malheiros Ed., 2007. v. 1.

. Princípios gerais de direito administrativo. Rio de Janeiro: Forense, 1969. v. 2.

MELLO, Rafael Munhoz de. Princípios constitucionais de direito administrativo sancionar: as sanções administrativas à luz da Constituição Federal de 1988. São Paulo: Malheiros Ed., 2007.

MIR, José Cerezo. Sanções penais e administrativas do direito espanhol. Revista Brasileira de Ciências Criminais. São Paulo, v. 1, n. 2, p. 27-40, abr./jun. 1993.

MODESTO, Paulo. Estágio probatório: questões controversas. Revista Eletrônica de Direito do Estado (REDE), Salvador, n. 10, abr./jun. 2007. Disponível em: <www.direitodoestado.com.br/rede/asp>. Acesso em: 13 nov. 2009.

Notas para um debate sobre o princípio constitucional da eficiência. Revista

Diálogo Jurídico, Salvador, v. 1, n. 2, maio, 2001. Disponível em: <http://www.direitopublico.com.br>. Acesso em: 29 jan. 2009.

MONTEIRO, Vera. As leis de procedimento administrativo: uma leitura operacional do princípio constitucional da eficiência. In: SUNDFELD, Carlos Ari; MUÑOZ, Guilhermo Andrés (Coords.). As leis de processo administrativo (Lei federal 9.784/99 e Lei paulista 10.177/98). 1. ed. 2.tir. São Paulo: Malheiros Ed., 2006.

MORAES, Alexandre de. Constitucionalização do direito administrativo e princípio da eficiência. In: FIGUEIREDO, Carlos Maurício; NÓBREGA, Marcos (Orgs.). Administração pública: direitos administrativo, financeiro e gestão pública: prática, inovações e polêmicas. São Paulo: Ed. Revista dos Tribunais, 2002.

Princípio da eficiência e o controle jurisdicional dos atos administrativos discricionários. Revista de Direito Administrativo, Rio de Janeiro, n. 243, p. 13-28, set./dez. 2006.

Reforma administrativa: Emenda Constitucional nº 19/98. 4. ed. São Paulo: Atlas, 
MORAES, Antonio Carlos Flores de. Legalidade, eficiência e controle da administração pública. Belo Horizonte: Fórum, 2007.

MORAES, Germana de Oliveira. Considerações gerais sobre a reforma administrativa Emenda Constitucional 19, de 04.06.1998. Revista Tributária e de Finanças Públicas, São Paulo, n. 34, p. 169-175, 2000.

Controle jurisdicional da administração pública. 2. ed. São Paulo: Dialética, 2004.

MORAIS, Dalton Santos. Os custos da atividade administrativa e o princípio da eficiência. Revista de Direito Administrativo, Rio de Janeiro, n. 237, p. 165-196, jul./set. 2004.

MOREIRA, Egon Bockmann. Processo administrativo: princípios constitucionais e a Lei 9.784/1999. 3. ed. atual. e aumen. São Paulo: Malheiros Ed., 2007.

MOREIRA NETO, Diogo de Figueiredo. Coordenação gerencial na administração pública. Revista de Direito Administrativo, Rio de Janeiro, n. 214, p. 35-53, out./dez. 1998.

- Coordenação gerencial na administração pública (administração pública e autonomia gerencial, contratos de gestão, organizações sociais. A gestão associada de serviços públicos: consórcios e convênios de cooperação). Revista da Procuradoria Geral do Estado da Bahia, Salvador, v. 24, p. 29-53, jan./dez. 1998.

O Estado e o futuro: prospectiva sobre aspectos da instituição estatal. In: SOUZA, Hamilton Dias de (Coord.). A reengenharia do estado brasileiro. Apresentação Hamilton Dias de Souza. São Paulo: Ed. Revista dos Tribunais, 1995.

Legitimidade e discricionariedade: novas reflexões sobre os limites e controle da discricionariedade. Obra premiada em $1^{\circ}$ lugar pela Ordem dos Advogados do Brasil - RJ Prêmio "José Ribeiro de Castro Filho". 2. ed. Rio de Janeiro: Forense, 1991.

A lei de responsabilidade fiscal e seus princípios jurídicos. Revista de Direito Administrativo, Rio de Janeiro, n. 221, p. 71-93, jul./set. 2000.

. Mutações do direito administrativo. 3. ed. rev. e ampl. Rio de Janeiro: Renovar, 2007.

Mutações nos serviços públicos. In: WAGNER JUNIOR, Luiz Guilherme Costa (Coord.). Direito público: estudos em homenagem ao professor Adilson Abreu Dallari. Belo Horizonte: Del Rey, 2004.

Reinstitucionalização da ordem econômica. 4. painel (Apresentado no XVII Congresso Brasileiro de Direito Constitucional). Cadernos de Direito Constitucional e Ciência Política, São Paulo, v. 5, n. 18, p. 87-95, jan./mar. 1997.

Uma nova administração pública. Revista de Direito Administrativo, Rio de Janeiro, n. 220, p. 179-182, abr./jun. 2000. 
MOURA, Paulo Veiga e. Função pública: regime jurídico, direitos e deveres dos funcionários e agentes. 2. ed. Coimbra: Coimbra Ed., 2001. v. 1.

NASCIMENTO, Amauri Mascaro. Curso de direito do trabalho: história e teoria geral do direito do trabalho: relações individuais e coletivas do trabalho. São Paulo: Saraiva, 2007.

NETTO, Luísa Cristina Pinto e. A contratualização da função pública. Belo Horizonte: Del Rey, 2005.

NIEBUHR, Joel de Menezes. Princípio da eficiência. Revista Trimestral de Direito Público, São Paulo, n. 30, p. 134-140, 2000.

NIGRO, Felix. Administração de pessoal no serviço público. Trad. Maria de Lourdes Lima Modiano. Rio de Janeiro: Fundação Getúlio Vargas, 1966.

NOBRE JUNIOR, Edilson Pereira. Improbidade administrativa: alguns aspectos controvertidos. Revista de Direito Administrativo, Rio de Janeiro, n. 235, p. 61-91, jan./mar. 2004.

Sanções administrativas e princípios de direito penal. Revista de Direito Administrativo, Rio de Janeiro, n. 219, p. 127-151, jan./mar. 2000.

OLIVEIRA, Regis Fernandes de. Infrações e sanções administrativas. 2. ed., rev., atual. e ampl. São Paulo: Ed. Revista dos Tribunais, 2005.

Servidores públicos. 2. ed. São Paulo: Malheiros Ed., 2008.

OSÓRIO, Fábio Medina. Direito administrativo sancionador. 2 ed. rev., atual. e ampl. São Paulo: Ed. Revista dos Tribunais, 2005.

O "novo" sistema judicial brasileiro: significados e significantes. In: OSÓRIO, Fábio Medina; SOUTO, Marcos Juruena Villela (Coords). Direito administrativo: estudos em homenagem a Diogo de Figueiredo Moreira Neto. Rio de Janeiro: Lumen Juris, 2006.

. Novos rumos da gestão pública brasileira: dificuldades. In: WAGNER JUNIOR, Luiz Guilherme Costa (Coord.). Direito público: estudos em homenagem ao professor Adílson Abreu Dallari. Belo Horizonte: Del Rey, 2004.

Teoria da improbidade administrativa: má gestão pública, corrupção e ineficiência. São Paulo: Ed. Revista dos Tribunais, 2005.

PALERMO, Fernanda Kellner de Oliveira. O princípio da proporcionalidade e as sanções penais nos contratos administrativos. Revista de Direito Administrativo, Rio de Janeiro, $\mathrm{n}$. 227, p. 321-337, jan./mar. 2002.

PASTORE, José. Redefinindo o que é trabalho. In: SOUZA, Hamilton Dias de (Org.). A reengenharia do Estado brasileiro. São Paulo: Ed. Revista dos Tribunais, 1995. 
PEREIRA, Cesar A. Guimarães. Discricionariedade e apreciações técnicas da administração. Revista de Direito Administrativo, Rio de Janeiro, n. 231, p. 217-267, jan./mar. 2003.

PEREIRA, Luiz Carlos Bresser. Crise econômica e reforma do Estado no Brasil: para uma nova interpretação da América Latina. São Paulo: Ed. 34, 1996.

Reforma do Estado para a cidadania: a reforma gerencial brasileira na perspectiva internacional. São Paulo: Ed. 34; Brasília: ENAP, 1998.

PEREIRA JUNIOR, Jessé Torres. Da reforma administrativa constitucional. Rio de Janeiro: Renovar, 1999.

PLANO Diretor da Reforma do Estado. Brasília, nov. 1995. Bresser-Pereira Website. Disponível em: $<$ http://www.bresserpereira.org.br/Documents/MARE/PlanoDiretor/planodiretor.pdf>. Acesso em: 21 out. 2008.

PRATES, Marcelo Madureira. Sanção administrativa geral: anatomia e autonomia. Coimbra: Livr. Almedina, 2005.

PRATS I CATALÁ, Joan. Direito e gerenciamento nas administrações públicas - notas sobre a crise e renovação dos respectivos paradigmas. Revista do Serviço Público, ano. 47, v. 120, n. 2, p. 23-45, maio/ago. 1996.

RAMALHO, Maria do Rosário Palma. Do fundamento do poder disciplinar laboral. Coimbra: Livr. Almedina, 1993.

RAMOS, Dora Maria de Oliveira. Terceirização na administração pública. São Paulo: LTr, 2001.

RAMOS, Elival da Silva. A proteção aos direitos adquiridos no direito constitucional brasileiro. São Paulo: Saraiva, 2003.

REALE JÚNIOR, Miguel. Reforma administrativa e governabilidade. Colab. Paulo Rabello de Castro, Cláudia Maria Costin, Pedro Luiz Barros Silva. Extraído da mesa redonda sobre o tema "reforma administrativa e governabilidade", organizada pela Fundação Konrad-Adenauer-Stiftung na sede do Parlamento Latino-Americano, no dia 24 de abril de 1995. São Paulo: Fundação Konrad-Adenauer-Stiftung, 1995.

RIGOLIN, Ivan Barbosa. Comentários ao Regime Único dos Servidores Públicos Civis. 3. ed. atual. São Paulo: Saraiva, 1994.

RIVERO, Jean. Direito administrativo. Trad. Rogério Ehrhardt Soares. Coimbra: Livr. Almedina, 1981.

ROCHA, Cármen Lúcia Antunes. Princípios constitucionais da administração pública. Belo Horizonte: Del Rey, 1994. 
ROCHA, Silvio Luís Ferreira da. Duração razoável dos processos judiciais e administrativos. Interesse Público, v. 8, n. 39, p. 73-80, 2006.

SANCHO ROYO, David. Gestión de servicios públicos: estrategias de marketing y calidad. Madrid: Tecnos; Universitat Pompeu Fabra, 1999.

SANTAMARIA PASTOR, Juan Alfonso. Estado social de derecho y control jurídico de eficacia de la administración pública. Revista Brasileira de Direito Público - RBDP, Belo Horizonte, ano 5, n. 19, p. 165-179, out./dez. 2007.

SANTIN, Valter Foleto. Controle judicial da eficiência do serviço de segurança pública na prevenção e repressão ao crime. 2003. Tese (Doutorado) - Faculdade de Direito, Universidade de São Paulo, São Paulo, 2003.

SANTOS, Alvacir Correa dos. Princípio da eficiência da administração pública. São Paulo: LTr, 2003.

SCORSIM, Ericson Meister. Os serviços públicos e o princípio da eficiência. BDA: boletim de direito administrativo, São Paulo, v. 18, n. 3, p. 193-200, mar. 2002.

SILVA, José Afonso da. Comentário contextual à Constituição. 5. ed. de acordo com a Emenda Constitucional 56, de 19.12.2007. São Paulo: Malheiros Ed., 2008.

Curso de direito constitucional positivo. 32. ed. rev. e atual. (até a Emenda Constitucional n. 57, de 18.12.2008). São Paulo: Malheiros Ed., 2009.

SILVA SÁNCHES, Jesús-María. Eficiência e direito penal. Trad. Maurício Antonio Lopes. Barueri: Manole, 2004 (Estudos de direito penal; v. 11).

SOARES, Fabiana de Menezes. Função administrativa, estabilidade e princípio da neutralidade: alguns apontamentos sobre a reforma administrativa. Revista de Direito Administrativo, Rio de Janeiro, n. 211, p. 301-318, jan./mar. 1998.

SUNDFELD, Carlos Ari. Fundamentos de direito público. 4. ed. 3 tir. São Paulo: Malheiros Ed., 2002.

TÁCITO, Caio. Transformações do direito administrativo. Revista de Direito Administrativo, Rio de Janeiro, n. 214, p. 27-34, out./dez. 1998.

TOMÁS MALLÉN, Beatriz. El derecho fundamental a una buena administración. 1. ed. Madrid: Instituto Nacional de Administração Pública, 2004. (Estudios).

VALLE, Vanice Lírio do. Direito fundamental à boa administração, políticas públicas eficientes e prevenção do desgoverno. Interesse Público, Porto Alegre, v. 10, n. 48, p. 87109, mar./ago. 2008. 
VERZOLA, Maysa Abrahão Tavares. A sanção no direito administrativo brasileiro. 2008. Dissertação (Mestrado) - Faculdade de Direito, Universidade de São Paulo, São Paulo, 2008.

VITTA, Heraldo Garcia. Aspectos da imposição de penalidades administrativas. Revista do Tribunal Regional Federal da $3^{a}$ Região, São Paulo, n. 78, p. 31-48, jul./ago. 2006.

O princípio da eficiência e a discrição administrativa. Revista do Instituto de Pesquisas e Estudos, Bauru, n. 36, p. 405-407, dez./abr. 2002-2003.

. A sanção no direito administrativo. São Paulo: Malheiros Ed., 2003.

WIMMER, Miriam. As relações de sujeição especial na administração pública. Direito Público, Porto Alegre, v. 5, n. 18, p. 31-53, out./dez. 2007.

ZANOBINI, Guido. Le sanzioni amministrative. Torino: Fratelli Bocca Editori, 1924.

. Rapporti fra il diritto amministrativo e il diritto penale. In: SCRITTI vari di diritto pubblico. Milano: Giuffrè, 1955. 